ISSN 1045-6333

\title{
THE POLITICAL ECONOMY OF INSIDER TRADING LEGISLATION AND ENFORCEMENT: INTERNATIONAL EVIDENCE
}

Laura Nyantung Beny

Discussion Paper No. 348

$01 / 2002$

Harvard Law School

Cambridge, MA 02138

The Center for Law, Economics, and Business is supported by a grant from the John M. Olin Foundation.

This paper can be downloaded without charge from:

The Harvard John M. Olin Discussion Paper Series: http://www.law.harvard.edu/programs/olin_center/ 
JEL Class: G38, K20, K22

\title{
The Political Economy of Insider Trading Legislation and Enforcement International Evidence
}

\author{
Laura Nyantung Beny*
}

\begin{abstract}
In this paper, I present a political economy analysis of insider trading laws and enforcement. I argue that there is greater (private and public) support for enacting insider trading legislation and enforcing such legislation (once it is in place) in countries where the confluence of legal, financial, political and institutional factors fosters and maintains the development of an "outsider" financial system. Conversely, I argue that there is less (public and private) support for insider trading legislation and enforcement in countries where these factors facilitate an "insider" financial system. I also argue that insider trading regulation might be consistent with social welfare, contrary to the public choice theory of insider trading regulation espoused by Haddock and Macey (1987). From these propositions, I derive several testable hypotheses about the relative timing of enactment and enforcement of insider trading rules among countries. I then test these hypotheses using time series data from the largest possible cross section of countries, employing a regression technique referred to as duration analysis. The paper's findings generally support the prediction that "outsider" systems tend to enact and/or enforce insider trading laws relatively earlier than "insider" systems, controlling for the age and the level of development of the stock market.
\end{abstract}

\footnotetext{
* John M. Olin Fellow in Law and Economics, Harvard Law School, 2000-2001; Assistant Professor of Law, University of Michigan Law School, beginning 2003.
} 


\title{
The Political Economy of Insider Trading Legislation and Enforcement: International Evidence
}

\author{
Laura Nyantung Beny ${ }^{*}$
}

(C) 2002 Laura Nyantung Beny. All rights reserved.

"[L]egal reforms, while important, are likely to follow, rather than precede, market changes - as happened in both the U.S. and the U.K. Once however a constituency for [a] liquid and transparent securities market is thus created, it will predictably seek and secure legislation that fills in the enforcement gap that selfregulation leaves." John Coffee (2001) ${ }^{1}$

\section{Introduction}

\section{A. Background and Research Question}

Insider trading is a controversial subject in the United States and elsewhere. In the United States, it receives considerable attention both in academic and policy circles and in the popular media. In the media, insider trading is associated with Wall Street excesses: financial greed and wheeler dealing (e.g., the Milkin and Boesky cases of the 1980s). In academia and policy circles, the debate centers on the desirability of regulating insider trading. Opponents of insider trading legislation claim that such legislation favors special interests at the expense of efficiency, while those in support of banning insider trading argue that it is efficiency reducing and banning the practice boosts social welfare. Several recent empirical studies address the economic implications

\footnotetext{
* John M. Olin Fellow in Law and Economics, Harvard Law School, 2000-2001; Assistant Professor of Law, University of Michigan Law School, beginning 2003. I am grateful to Andrei Shleifer, Raphael La Porta, Merritt Fox, and John Coffee for valuable comments and suggestions. In addition, I am grateful to Steven Shavell and the Olin Center for Law, Economics and Business at Harvard Law School for providing generous financial support and resources. This paper is based on Chapter 3 of my Ph.D. dissertation in Economics, Harvard University.

${ }^{1}$ Coffee (2000), Abstract.
} 
of insider trading laws and enforcement. These studies tend to support the claim that insider trading legislation is efficiency enhancing.

This is puzzling. If insider trading legislation promotes efficiency, why was insider trading legal for so long in so many countries, and why do insiders (and their associates) continue to trade with impunity in many markets in which insider trading has long since been illegal on the books? Internationally, with few exceptions, insider trading legislation and enforcement are phenomena of the late 1980s and 1990s. Stock markets are much older than insider trading regulation and enforcement (see Table 1). Even if insider trading is efficient and regulation inefficient, as some claim, then it is still puzzling why countries are moving toward greater insider trading regulation and enforcement as arm's length finance is increasing in relative importance. Whether insider trading legislation is efficiency enhancing (as the evidence suggests) or simply an inefficient redistributive policy, the dynamics of insider trading policy is an interesting research question.

This paper seeks to explain the differential timing of insider trading regulation and enforcement across countries between 1980 and 1997. ${ }^{2}$ I posit that both public (efficiency) and private (distribution) elements constitute the demand for (or opposition to) insider trading legislation. Whether opponents or proponents of insider trading legislation prevail depends on a confluence of financial, legal, political, and institutional factors, many of which vary across and within countries over time.

\footnotetext{
2 I do not attempt to explain why insider trading legislation and enforcement are phenomena of the late 1980s and 1990s. However, one reason might be that most countries liberalized their stock markets in 1980 or after. In addition, technological advances in recent decades have increased the level of sophistication of market surveillance, making detection of unusual trading activity and thus enforcement of insider trading laws more feasible.
} 


\section{B. Theoretical Approach and Empirical Methodology}

Since insider trading regulation concerns the assignment of property rights in corporate information, the issue has both private (distributional) and public (efficiency) dimensions. The framework developed in this paper takes into account both of these dimensions. ${ }^{3}$ As in Becker (1983), the distributional impact of insider trading determines the private constituencies that support and oppose insider trading regulation and enforcement, while the efficiency implications influence which interest group has an inherent advantage in lobbying for its favored policy.

The competing interest groups (broadly, insiders and outsiders) operate within a comprehensive context that includes the financial system, the legal environment, the political system and institutional characteristics. These separate elements (financial, legal, political, and institutional) foster in the aggregate a system tending either to favor insiders (so-called insider/control-oriented systems) or to favor outsiders (so-called outsider/arm's length systems). ${ }^{4}$ I characterize a system as an insider system if stock ownership is concentrated and trading thin and, in addition, the legal, political and/or institutional structures tend to favor financial and industrial incumbents over newcomers and outside investors. Conversely, I characterize a system as an outsider system if stock ownership is dispersed and the stock market is liquid and the legal, political and/or institutional structures enable outsiders to mount effective challenges against financial incumbents.

\footnotetext{
${ }^{3}$ Many theories of regulation emphasize either an efficiency rationale for regulation or a distributional rationale for regulation. In the spirit of Becker (1983), the model in this paper incorporates both rationales. This approach to the political economy of insider trading legislation reflects "the deeper [notion] that the fairness/efficiency debate in insider trading is merely a reprise of the public/private debate that characterizes many other areas of political and legal discourse....The place of information along [the] public/private continuum is especially problematic because, unlike most other valuable objects, information lies particularly close to the imaginary public/private dividing line.” Krawiec (2001), p. 448.
} 
I argue that, other things equal, insider systems are relative latecomers to insider trading regulation and enforcement compared to outsider systems. Effective demand for insider trading regulation is greater in outsider systems because outsiders harmed by insider trading constitute a more influential political-economic lobby relative to insiders. At the same time, since stock markets are more important to capital raising and allocative efficiency in arm's length systems, the public interest case for insider trading legislation and enforcement is more compelling in outsider systems. Both of these factors (private and public interests) increase the demand for an insider trading prohibition and enforcement in arm's length systems relative to outsider systems. Exploiting temporal and international variation in the explanatory factors between 1980 and 1997, I use duration analysis to test the prediction that outsider systems tend to enact and enforce insider trading laws earlier tha n outsider systems.

The paper is organized as follows. In Section 2, I outline the political economy ramifications of insider trading, discussing potential private (distributional) and public (efficiency) implications. I also describe the formal model presented in the Appendix. Section 3 presents several testable hypotheses. In Section 4, I describe the data sources and present several stylized facts. Section 5 explains the empirical methodology (duration analysis) and presents the results. Finally, in Section 6, I provide a summary of the main results and concluding remarks.

\section{The Political Economy of Insider Trading}

Insider trading legislation is fundamentally about the allocation of the property right in corporate information and hence about the distribution of rents derived from the use of such information (Goshen and Parchomovsky, 2000; Krawiec, 2001). The State

\footnotetext{
${ }^{4}$ This terminology is borrowed from Berglof (1997). See also Berndt (2000).
} 
creates and protects property rights. This makes a political economy framework an appropriate way to understand a country's decision to enact and/or enforce insider trading legislation. When insider trading is legal, the State assigns (by default) the property right in and associated private rents from corporate information to corporate insiders. In contrast, when insider trading is prohibited, the State assigns the property right and related rents to corporate outsiders. The relative political influence of these competing constituencies is an important determinant of the State's insider trading policy.

In addition, since property rights determine not only private rents but also the magnitude of social costs, ${ }^{5}$ I also consider the efficiency implications of insider trading in this section. Finally, I combine these considerations (distribution and efficiency) into a political economy theory of insider trading legislation.

\section{A. The Private Constituencies: Gainers and Losers from Insider Trading}

Insider trading creates private winners and losers. ${ }^{6}$ The identity of the winners is more obvious than the identity of the losers, but some categories of market participants are more clearly harmed by insider trading than others.

\section{Insiders and their Associates}

Corporate insiders consist of traditional or "primary" insiders, including executives, board members, officers, and controlling shareholders. The ir status gives them privileged access to corporate information and thus a potential trading advantage relative to outsiders. There are also "constructive" or "secondary" insiders like lawyers, accountants, investment bankers, and brokers and dealers, who may be privy to private

\footnotetext{
5 According to Demsetz, the underlying "function of property rights is that of guiding incentives to achieve a greater internalization of externalities," Demsetz (1967), p. 348.

${ }^{6}$ I am not convinced by the often made argument that insider trading produces no identifiable gainers or losers, simply because if that were the case, it would not be as controversial an issue as it obviously is.
} 
information by virtue of a contractual relationship with the firm or its shareholders. To the extent that they receive private information (i.e., information unavailable to the rest of the investing public) from insiders, relatives, personal and political associates of insiders might also be classified as insiders. ${ }^{7}$

"Primary" insiders generally gain from insider trading. U.S. evidence (e.g., Jeng, Metrick and Zechauser, 1999) suggests that insiders make superior profits (relative to the market) when they trade on the basis of public information. ${ }^{8}$ These studies are limited in that they are based on U.S. data and are confined to trading on the basis of publicly available and/or immaterial information. ${ }^{9}$ Insider trading on the basis of material, nonpublic information is undoubtedly even more profitable, especially in countries where there are fewer legal (as well as moral, political and institutional) constraints on insiders' self-dealing. Bris (2000) presents international evidence suggesting that insider trading on the basis of private information is highly profitable in the context of corporate takeovers.

Some "Chicago"/neoclassical theories of insider trading (e.g., Carlton and Fischel, 1983) dismiss the notion that insider trading benefits corporate insiders. They argue that insiders do not gain on net, because their salaries are reduced commensurate with their insider trading profits. The argument is not convincing, however. By definition, insider trading is not transparent. Even in the absence of a legal prohibition, insiders have strong incentives to disguise their trading activity (see, e.g., Kraakman,

\footnotetext{
7 These persons are often referred to as "tippees," when they receive private information from insiders.

${ }^{8}$ Applying performance-evaluation techniques to reported U.S. insider transactions over 1975-1996, Jeng, Metrick and Zechauser (1999) find that a constructed portfolio of insiders' (top executives and other insiders) purchases over the prior year earns abnormal returns of approximately 40 basis points per month. They also find that insiders' sales do not earn abnormal returns.

${ }^{9}$ Immaterial information is information that, if publicly known, would not impact the stock's price. Material information would, if publicly known, affect the stock's price.
} 
1991). ${ }^{10}$ Another argument is that insider trading profits are not a windfall gain but are simply a means to compensate insiders for valuable entrepreneurial services (Manne, 1966). This argument assumes that insiders' compensation is adjustable in light of trading profits, a claim that I just questioned. A final argument is that insiders do not gain from insider trading because they pay for insider trading in the form of a higher cost of capital at the IPO or SEO stage, since investors discount share prices to reflect the probability of insider trading. ${ }^{11}$ However, insider trading is arguably a category of private benefit, the full potential costs of which insiders do not bear but rather impose on outsiders (Bebchuk and Jolls, 1999). ${ }^{12}$

Tippees (relatives, friends, business and political associates of corporate insiders) clearly gain when they trade on the basis of private information received from insiders. In several countries, much insider trading is done by politicians and government bureaucrats who receive private information in exchange for economic or political favors. Tippees' insider trading profits are a windfall gain since, unlike managers and other primary insiders, they are unlikely to increase firm value through entrepreneurial or productive services. One can expect tipping to be more prevalent in insider systems than in outsider systems, since business dealings tend to be relationship-based in these systems. $^{13}$

\footnotetext{
${ }^{10}$ Kraakman argues that "insiders would prefer to trade anonymously to preserve their informational monopolies, even if their activities were legal," Kraakman (1991) p. 50. One solution is to this problem is to require insiders to disclose their trades, as does Rule 16(b) in the United States.

${ }^{11}$ Manove (1989) models the discount.

${ }^{12}$ How much of the burden is passed on to outsiders depends on how accurately they are able to discount share prices to reflect value diversion due to insider trading.

${ }^{13}$ In India, for example, "the broker-promoter--politician-fund manager nexus...these days accounts for the biggest chunk of insider trading." Sucheta Dalal, "Nabbing insider traders: Easier said than done," August 16, 2001 http://www.rediff.com/money/2000/aug/16dalal.htm.
} 
Market professionals, like brokers, dealers, investment bankers and institutional investors might also benefit from insider trading due to the special relationships they have established with corporations and their management. Even in the United States, where insider trading has long been prohibited and the laws vigorously enforced, until recently it was common for investment bankers and other market professionals to receive confidential information ahead of the market from the corporations with whom they have business relations (see Goshen and Parchomovsky, 2000). In insider systems, where formal and informal constraints are weaker or non-existent, trading among market professionals is probably a common phe nomenon.

The foregoing potential gainers, particularly primary insiders and their business and political associates (i.e., the business and political elite) can be expected to lobby against both banning insider trading and vigorous enforcement of the laws, once they have been enacted. The story is a bit more complicated for market professionals. Market professionals could go either way. In insider systems, they are likely to be aligned with insiders, since information-sharing (tipping) between industrialists and financiers is more prevalent than in outsider systems.

\section{Outsiders}

Informed traders (arbitrage traders) experience direct losses as a result of insider trading. Information traders include market professionals, like analysts, broker-dealers, market makers and sophisticated investors. Informed traders are insiders' main competitors for trading profits, and they receive most of their income from trading. They consistently lose relative to insiders when the latter trade on the basis of private information because, although they are well informed relative to outsiders, informed 
traders are at a distinct informational disadvantage vis-à-vis insiders (Haddock and Macey, 1987a; Georgakopoulos, 1993; Shin, 1996; Goshen and Parchomovsky, 2000). In Beny (2001a), I provide indirect evidence that arbitrage traders are discouraged by insider trading, by demonstrating that there is a positive correlation between the stringency of insider trading laws and stock price informedness, since stock prices are more informative when arbitrage activity is vibrant. Because they lose relative to insiders, informed traders should lobby for more stringent insider trading laws and enforcement, unless they are co-opted by insiders, a possibility considered above. ${ }^{14}$

Since they trade frequently, liquidity traders (a group that includes institutional investors, like pension funds, mutual funds, insurance companies, index traders, and foreign investors) are mainly concerned with minimizing trading costs. Their trading is largely driven by exogenous factors like portfolio realignment or short-term consumption rather than by new information. Theoretical (e.g., Glosten and Harris, 1988; Shin, 1996) and empirical (e.g., Copeland and Galai, 1983; Glosten and Harris, 1988; Stoll, 1989) studies suggest that insider trading increases liquidity traders' transaction costs. Thus, liquidity traders should support insider trading legislation and enforcement, other things equal.

It is less clear how insider trading affects naïve (i.e., uninformed) outside shareholders who infrequently trade. Small investors might be indirectly harmed by insider trading due to greater mutual and pension fund fees passed on to them by institutional investors who experience increased trading costs. In addition, if insider trading is an agency cost (i.e., an inefficient private benefit) and the market

\footnotetext{
${ }^{14}$ This is in fact what happened in the United States, according to Haddock and Macey (1987a). Market professionals vigorously lobbied for tougher insider trading sanctions in order to reduce their competitive
} 
systematically underestimates the amount of trading, outside investors are harmed by insider trading, since they are paying more than the shares' true worth. On the other hand, if insider trading reduces agency costs, minority shareholders benefit from it. ${ }^{15}$

The foregoing potential losers (informed traders, liquidity traders and, possibly, small investors) should favor an insider trading ban and vigorous enforcement of the laws once they have been enacted.

\section{B. Social Welfare (Efficiency) Considerations}

Apart from its private (distributional) effects, theory and evidence suggest that there are several channels through which insider trading might be socially costly. ${ }^{16}$

\section{Price Informativeness and Capital Allocation}

Arbitrage (informed) traders play a positive role in price formation, both in the extent and kind of information that is impounded in stock prices (Morck, Yeung and $\mathrm{Yu}$, 2000; Goshen and Parchomovsky, 2000). Risk arbitrageurs invest resources in discovering firm-specific information. Their reward is the profit that they earn by trading with their superior information against less informed investors. Risk arbitrageurs gather proprietary information about firms until the marginal cost of doing so is greater than the marginal benefit. The collective trading of many risk arbitrageurs leads to more efficient capitalization of information into stock prices (Grossman, 1976; Shleifer and Vishny, 1997). In particular, more firm-specific arbitrage by informed traders leads to more firmspecific price variation, making stock prices more informative (French and Roll, 1986; Roll, 1988).

\footnotetext{
informational disadvantage relative to corporate insiders.

${ }^{15}$ In Beny (1999, 2001a,b) I address the agency implications of insider trading and its regulation.

16 There is some theoretical work (e.g., Manne, 1966; Carlton and Fischel, 1983) arguing that insider trading is socially beneficial, but I am not aware of any empirical support for this claim.
} 
Wurgler (2000) shows that capital is more efficiently allocated in the economy the greater the amount of firm-specific information that is capitalized into stock prices. Therefore, if insider trading discourages informed/arbritrage traders, it imposes a negative externality on the economy by reducing the informativeness of stock prices. ${ }^{17}$ In Beny (2001a), I show that there is a positive correlation between stock price informativeness and the stringency of insider trading laws, suggesting that capital allocation is less efficient in countries with lax insider trading legislation.

\section{Capital Constraints and the Cost of Capital}

Capital constraints limit the range of feasible investments in the economy, in turn limiting economic growth (Bekaert, Harvey, and Lundblad, 2001). A lower cost of capital makes investments more profitable and encourages the entry of new entrepreneurs into the capital market. Using international time series data, Bhattacharya and Daouk (2001) demonstrate that enforcing insider trading legislation is followed by a $5 \%$ decrease in the cost of capital (measured by stock returns relative to an international benchmark). ${ }^{18}$ Their finding suggests that the market's perception of unregulated insider trading makes capital more expensive, while serious enforcement of insider trading laws significantly relaxes capital constraints. Hence enforcing an insider trading ban could lead ultimately to increased economic growth.

\section{Transaction Costs and Liquidity}

Liquid markets are socially valuable because greater liquidity makes purchasing and disposing of shares on short notice, at the appropriate price, easier for investors. The

\footnotetext{
${ }^{17}$ Morck, Yeung, and Yu (2000) present cross-country evidence that stock price infomativeness and investor protections are positively correlated, implying that beneficial arbitrage activity is greater in countries where the threat of expropriation is lower.
} 
more liquid the market, the more willing investors are to participate in it. This is true for both primary and secondary markets. Amihud and Mendelson (1986) confirm that investors value liquidity by showing that companies whose shares are more liquid must pay investors a lower expected rate of return than companies with less liquid shares. That is, companies whose shares are more liquid have a lower cost of equity capital. Liquid markets might also mitigate agency costs, by lowering the opportunity cost of monitoring and facilitating the market for corporate control (Maug, 2000; Berndt, 2000). ${ }^{19}$ As noted above, however, insider trading increases transaction costs and thus reduces stock market liquidity.

\section{A Political Economy Theory of Insider Trading Legislation}

According to public interest theories of regulation, governments undertake reforms in order to correct market failures and to enhance economic efficiency. Hence insider trading regulation might be an attempt by the government to correct a socially inefficient market failure that market participants are unwilling or unable to solve through private contracting. The theoretical weakness of public interest theories of regulatory change, however, is that they are vague about the mechanism(s) through which the need for regulatory remediation is translated into public policy (Posner, 1974). They leave unanswered the question about when the government has the requisite political will to undertake efficiency-enhancing reforms. Indeed, market inefficiencies often persist for long periods without governmental intervention, due to effective opposition to reform from the entrenched political and economic elite.

\footnotetext{
${ }^{18}$ However, Bekeart, Harvey and Lundblad (2001) show that the positive effect of enforcing insider trading laws on the cost of capital is not robust to controlling for stock market liberalization.

${ }^{19}$ But see Bhide (1993), who argues that greater liquidity hinders corporate monitoring.
} 
Private interest theories of regulation (e.g., Stigler, 1971; Peltzman, 1976) are also deficient in that they posit competition between special interest groups as the sole determinant of who wins in the regulatory game. ${ }^{20}$ These theories generally consider regulatory intervention to be socially inefficient, overlooking the empirical reality that regulation sometimes increases economic efficiency. ${ }^{21}$ Becker (1983) integrates the private and public interest approaches in a model of interest-group competition. In Becker's model, interest groups that support inefficient policies have an inherent disadvantage in the competition for political influence.

In the Appendix, I present a model of special interest competition for influence over a government regulator who sets insider trading policy. Insiders prefer to trade with impunity while outsiders prefer a ban on insider trading. Which group prevails depends on the relative efficiency of the competing groups' political expenditures, which in turn depends on the relative sizes of the groups as well as their ability to control free riding among their members. ${ }^{22}$ As in Becker's (1983) model, a group has an inherent advantage if the policy that it favors raises social welfare and an inherent disadvantage if its preferred policy is socially inefficient. Thus, if insider trading is inefficient, insiders are inherently disadvantaged relative to outsiders. Nevertheless, a group that favors an inefficient policy may overcome its inherent disadvantage if it is more skilled at exerting political influence. See Becker (1983). Therefore, if insiders have more influence over policy makers than outsiders they can still successfully oppose tougher insider trading laws and enforcement, even if insider trading is socially inefficient. In the next section, I

\footnotetext{
${ }^{20}$ Haddock and Macey (1987a) apply this type of model to insider trading regulation, and argue that insider trading legislation is the result of demand from powerful special interests.

${ }^{21}$ Johnson and Shleifer (1999) aptly note how the Coasians are more Coasian than Coase was himself.

${ }^{22}$ See generally Mancur Olson (1965).
} 
hypothesize that this is likely to be the case in insider systems. Consequently, insider systems tend to impose and enforce insider trading laws later than outsider systems, controlling for other factors.

\section{Testable Hypotheses: Outsider versus Insider Systems}

In this section, I formulate testable hypotheses about the factors influencing the relative timing of countries' enactment and enforcement of insider trading laws. The factors (financial, legal, political, and institutional) individually and collectively tend to maintain or foster either of the two systems, insider versus outsider.

\section{A. Financial Determinants}

As stock markets become larger and more liquid and ownership more dispersed, both the private and the public stakes are raised. In liquid stock markets, the opportunities for insider trading are more numerous and more profitable (Maug, 2000; Bris, 2000). In addition, the social efficiency implications of insider trading become more important as the stock market develops and opens up for several reasons. First, equity finance is increasing in importance compared to alternative sources of corporate finance. Therefore any market distortions due to insider trading become more socially costly, giving outsiders a competitive advantage over insiders in the competition over insider trading policy (Becker, 1983). ${ }^{23}$ Second, as the stock market opens up, the capital supply becomes more elastic, further increasing the advantage of outsiders relative to business and financial incumbents (Becker, 1983; Rajan and Zingales, 2001). These confluent factors (greater and more profitable opportunities for insider trading, more

\footnotetext{
${ }^{23}$ Becker's (1983) model of interest group competition emphasizes that groups (special interest groups and taxpayers) opposed to an inefficient (de)regulation have a greater relative advantage in opposing such (de)regulation the greater are its deadweight costs.
} 
influential outsider constituencies, and greater potential social costs) produce a more intense conflict over insider trading policy as the stock market develops.

There are several potential channels through which outsiders become more influential as stock markets develop. First, there are simply more of them, making their aggregate interests more important relative to national wealth. ${ }^{24}$ Augmenting domestic outsider constituencies, foreign investors are another potential source of demand for insider trading legislation and enforcement. ${ }^{25}$ Second, as stock markets develop, institutions emerge that help to mitigate the free riding problems that stymie collective action and to disseminate information among dispersed investors. ${ }^{26}$ Investor associations are one example. In the United States, for example, the Investor's Clearinghouse is an online forum run by the Alliance for Investor Education. ${ }^{27}$ The website provides information to investors on a wide variety of topics including the determinants of mutual fund fees. Similarly, the Institutional Investor Online provides articles about a range of issues of concern to institutional investors - like the dangers of investing in overseas markets, like China, that are rife with insider trading and market manipulation. ${ }^{28}$

Self-regulatory institutions, like stock exchanges, that regulate their members are another example of institutions that might emerge to protect investors as the stock market

\footnotetext{
${ }^{24}$ Becker's (1983) model illustrates that more members may increase the effective influence of special interest groups, if the scale effect outweighs the free riding effect of an increase in group size.

${ }^{25}$ Bakaert, Harvey and Lundblad argue that "[i]t is possible that the enactment of [insider trading] rules are particularly valued and perhaps demanded by foreigners before they take the risk of investing in emerging markets." Bekaert, Harvey and Lundblad (2000), p. 27. The internationalization of stock markets has led to a proliferation of regulatory harmonization efforts among countries, e.g., through the auspices of institutions like IOSCO and bilateral agreements between the SEC and foreign market regulators. Arguably, this has generated a "race-to-the-top" in the sense that many countries have agreed to amend their laws in order to satisfy minimum standards of securities regulation.

${ }^{26}$ In the theoretical model in the Appendix, mechanisms that reduce free riding problems are considered to increase the "productivity" of political expenditures. Becker (1983).

$27<$ http://www.investoreducation.org/index.cfm. $>$.

$28<$ http://www.iimagazine.com/channel/other/20010412000434.htm>.
} 
develops (Cheffins, 2000; Coffee, 2001). ${ }^{29}$ Stock exchanges earn a substantial part of their profits from commissions, so they are naturally interested in maximizing trading volume. To that end, they often regulate their members, among whom are stock-issuing firms as well as market professionals like brokers and dealers, independently of any official regulation. ${ }^{30}$ Official regulation tends to follow self-regulation, both to formalize the existing institutions and to fill in the enforcement gaps. According to Coffee (2001),

[e]ven when a strong private institutional structure exists (as it did in the case of the NYSE), there are still important deficiencies which require legislative intervention in order to provide adequate enforcement. Legislative action is thus likely to follow, rather than precede, the appearance of securities markets because a constituency of public investors must first arise before there will be pressure for legislative reform that intrudes upon the market. In addition, the legislature cannot anticipate problems that it has never seen [also] severe constraints exist on both the incentives and ability of a private body (such as a stock exchange) to enforce rules against its member firms and its listed companies....the enforcement shortfall that is inherent in a self-regulatory system [is due to] several different reasons: (1) A private body has weak incentives to enforce rules against its own members and clients; (2) Enforcement is too costly for a private body to undertake on a thorough-going basis; and (3) Private bodies necessarily lack the investigative tools and punitive sanctions that the state has at its disposal. ${ }^{31}$

Hence, as stock markets develop, private and governmental entities tend to emerge.

These bodies are an important factor in the emergence of new regulations governing the stock market and the enforcement of such regulations in response to increased private and public demand. ${ }^{32}$

\section{Hypothesis 1}

\footnotetext{
${ }^{29}$ According to Coffee, "[b]y a variety of means, including a substantial self-regulatory component, both the United States and the United Kingdom developed legal and institutional mechanisms that enabled dispersed ownership to persist. Generally, these mechanisms followed, rather than preceded, economic changes, but they did protect and facilitate the growth of dispersed ownership." Coffee (2001), p.44.

${ }^{30}$ In 1929, "the Hatry scandal produced little, if any, legislation, but forced the LSE to accept some role as a guardian of issuer quality....By the 1950s, the LSE's listing rules had been tightened to require issuers to reveal all material information on an ongoing basis." Coffee (2000), p. 44.

${ }^{31}$ Coffee (2000), pp. 47, 49.

${ }^{32}$ In the U.S., for example, the SEC posts proposed rules on its website, and solicits comments from interested parties. See 〈http://www.sec.gov/rules/submitcomments.htm $>$ The publication of proposed rules and solicitation of public comments creates a forum for discussion among interested groups and plays an important role in the translation of market participants' interests into regulatory policy.
} 
Countries with more developed stock markets - as measured by stock market capitalization, the number of listed domestic companies, foreign investment, and liquidity - enact and enforce insider trading legislation sooner than countries with less developed stock markets.

\section{B. Legal Determinants}

LLSV $(1997,1998)$ find that there are important financial differences between common law and civil law countries. Common law systems tend to have arm's length financial markets with dispersed ownership structures and institutions, whereas civil law systems tend to have "insider" systems with concentrated ownership structures. The different markets and institutions in common law and civil law countries foster the growth of different interest groups (LLSV, 1996b; Rajan and Zingales, 2000). Outside investors have relatively more influence vis-à-vis corporate insiders and the political elite in common law countries than they do in civil law countries. ${ }^{33}$ Hence there should be relatively earlier support for insider trading legislation and enforcement in common law countries, controlling for the level of fina ncial market development. In civil law systems, where ownership and control tend to be more highly concentrated, corporate insiders and the political elite are likely to pose a more formidable obstacle to insider trading legislation. ${ }^{34}$

Another cited difference among the legal traditions is how readily they adapt to changing circumstances. Beck, Demirguc-Kunt, and Levine (2001) present the "dynamic law and finance" theory that common law systems adapt more easily to changing circumstances:

[t]he common law is inherently dynamic as it responds case-by-case to the changing needs of society. This tends to limit the opportunities for large gaps to grow between the

\footnotetext{
${ }^{33}$ LLSV (1999b); see also Rajan and Zingales (2001).

${ }^{34}$ Maug (2000) demonstrates that controlling shareholders benefit when insider trading laws are lax. In a similar vein, Demsetz (1986) and Bhide (1993) argue that insider trading legislation reduces controlling shareholders' profits.
} 
demands of society and the law. Since laws must evolve efficiently to support financial development, the dynamic law and finance view predicts that common law is particularly effective in supporting financial institutions. Moreover, the inherently dynamic nature of the common law implies that countries that received the common law have received a legal tradition that will more naturally adapt to different socioceconomic conditions and more readily evolve with changing commercial requirements than countries with the French civil law. ${ }^{35}$

Coffee (2001) concurs that the decentralized nature of the common law system makes it more amenable to changing circumstances. ${ }^{36}$ This implies that common law countries are more apt to prohibit insider trading as the stock market develops.

\section{Hypothesis 2}

Common law countries enact and enforce insider trading legislation earlier than civil law countries, controlling for the level of development of the stock market.

\section{Political Determinants}

The political theory of financial development emphasizes the importance of politics (both process and ideology) to financial market evolution. ${ }^{37}$ The political process is pivotal in terms of which special interest group/groups is/are able influence the State to redistribute rents toward itself/themselves at the expense of competing groups. I posit that the status quo (unregulated insider trading, or an as yet non-enforced insider trading ban) is more easily challenged when the political system is more open and competitive. That is because entrenched interests - the corporate and political elite - are relatively weaker in such systems. In order to effect a change in the status quo, outsiders must overcome these entrenched interests. The success of the outsider constituencies in

\footnotetext{
35 Beck, Demirguc-Kunt, and Levine (2001), p. 17.

${ }^{36}$ According to Coffee, "the more decentralized character of common law legal institutions [perhaps] facilitated the rise of both private and semi-private self-regulatory bodies in the U.S. and the U.K., whereas in civil law systems the state retained a relative monopoly over law-making institutions." Coffee (2000), p. 53. See also, Coffee (2001), pp. 59-64.
} 
achieving their favored policy depends importantly on the openness and competitiveness

of the political and legislative processes. ${ }^{38}$ When these processes are open and

contestable, outsiders are more likely to prevail. ${ }^{39}$

\section{Hypothesis 3}

Countries with more open and competitive political structures enact and enforce insider trading legislation earlier than countries with less open and competitive political structures, controlling for stock market development.

The ideological orientation of the government is also relevant. According to Roe (2000),

[i]n social democracies - nations committed to private property, whose governments play a large role in the economy, emphasize distributional considerations, and favor employees over capital-owners when the two conflict - public policy emphasizes managers' natural agenda and demeans shareholders' natural agenda. ${ }^{40}$

Roe maintains that social democracies "do not want unbridled shareholder wealth maximization, and, hence [emasculate] shareholder wealth maximization institutions." ${ }^{, 4}$ This implies that, other things equal, left-leaning governments are less likely to redistribute the property right in inside information to outsiders away from the business and political elite.

\footnotetext{
${ }^{37}$ See, e.g., Beck, Demirguc-Kunt, and Levine (2001); Rajan and Zingales (2001); Roe (2000, 2001); Pagano and Volpin (1999).

${ }^{38}$ According to LLSV (1999a), "[g]overnments become massively redistributive when there are relatively few very powerful groups with different interests, not when there are many relatively weak groups each pushing in its own direction."

${ }^{39}$ The United States is a case in point: the American political process has been sufficiently open to enable outsiders to mount successful challenges (including banning insider trading) against corporate constituencies from time to time.

${ }^{40}$ Roe (2000), pp. 3-4.

${ }^{41}$ Roe (2000), p. 4. Coffee disagrees, arguing that a more "feasible political explanation is....that power seeking nationalists could use banks as their agents and that banks, once entrenched, had natural reason to resist the rise of rivals for their business." Coffee (2000), p. 53. LLSV (1999b) also emphasize the role of State intervention, arguing that for historical and cultural reasons Europeans support greater State intervention than Americans.
} 


\section{Hypothesis 4}

Countries with left-leaning governments/legislatures enact and enforce insider trading laws later than countries with less right-leaning governments/legislatures, controlling for stock market development.

\section{Institutional Determinants}

LLSV (1999a) argue that good government is essential for economic growth.

They demonstrate empirically that good governments allocate and protect property rights in a manner consistent with economic prosperity, and the maintenance of orderly markets and societies. Good governments are also more diligent at enforcing the laws. Specific institutions (laws, enforcement, structures of accountability, etc.) constitute the mechanisms through which high quality governments promote growth. ${ }^{42}$

I argued above that the accumulating evidence suggests that insider trading is socially inefficient. Insider trading is associated with a higher cost of capital (Bhattacharya and Daouk, 2000) and less liquid markets (Beny, 1999, 2001a; Bhattacharya and Daouk, 2000). It follows that better governments in the LLSV (1999a) sense are more likely to ban insider trading, thus allocating the property right in corporate information to its most efficient users (outsiders). Having assigned the right in this manner, high quality governments are also more likely to enforce the insider trading ban, holding constant the incidence of violation.

In the empirical tests of Section 5, I use two proxies for the quality of government and institutions: the level of government corruption and religious affiliation of the population. Opponents of insider trading are more likely to prevail in the competition

\footnotetext{
${ }^{42}$ For example, using Poland and the Czech Republic as two contrasting cases, Johnson and Shleifer (1999) show that orderly and prosperous stock markets are fostered by efficient securities regulations.
} 
among special interests when the government is less corrupt. Corrupt regimes tend to be more insider-based than less corrupt regimes. Also, when there is more corruption, public decision-making is less open and transparent, biasing special interest competition in favor of the political and economic elite. The less corrupt is the government, the less susceptible it is to 'capture' by powerful groups that favor the status quo (in this case, unrestricted insider trading and other forms of insider 'self-dealing') and the more it is inclined to pursue welfare inc reasing market reforms. In addition, Shavell and Polinsky (1999) show that laws are less likely to be enforced in the presence of corruption. This is verified by cross-country empirical studies showing that there is a significant negative correlation between corruption and bureaucratic efficiency/law enforcement. (Mauro, 1995). Therefore, more corrupt regimes are also less likely to enforce insider trading laws, once they are in place.

For reasons that are less clear, LLSV (1999a) demonstrate that Protestant countries have better governments than Catholic and Muslim countries. Landes (1998) claims the reason is that Catholicism and Islam are inherently (culturally) antithetical to institutional development. LLSV (1999a) argue that the real underlying reason is not culture, but politics. That is, xenophobia and intolerance are used to fulfill the political, rather than the doctrinal/evangelical, aspirations of the ruling class. Whatever the reason, LLSV (1999a) show that religion is a good instrument for institutional/government quality.

\section{Hypothesis 5}

Countries with good government enact and enforce insider trading laws earlier than countries with bad government, holding constant stock market development. 


\section{E. Political "Backlash" Avoidance and Restoration of Public Confidence}

Public scandals might precipitate insider trading legislation and enforcement, irrespective of the nature of the system (insider or outsider). In some countries and periods, the public may well be aware that insider trading occurs with some frequency, but that perception does not generate opposition threatening either the market or the political status quo. However, a few high profile insider trading scandals may spark public outrage that, at best, reduces public confidence in the stock market and, at worst, threatens the political status quo. The government may respond by enacting securities market reforms, including banning insider trading or stepping up the enforcement of existing laws, in order to restore public confidence in the stock market and/or to avoid political backlash that could create even more inefficiencies than insider trading itself might create. ${ }^{43}$

This occurred in the United States in the 1930s after the stock market crash, which precipitated the creation of federal securities regulations and an enforcement agency (the SEC). Again, in the 1980s, during a period of hostile takeovers and highly publicized insider trading scandals (like the Milkin and Boesky cases), the U.S. Congress and the SEC responded to the perceived excesses with heightened insider trading sanctions and enforcement. According to Coffee (2001), Europe has not yet experienced the scandals elemental to securities market reform:

[t]he history of both the U.S.'s and the U.K.'s system of securities regulation...suggests that [reform in Europe] may only succeed once it is scandal driven. Both the panEuropean market and the requisite scandals have not arrived. ${ }^{44}$

\footnotetext{
43 See Roe (1998). Of course, the government may simply do nothing as chaos unfolds as Roe points out.
} 
In the empirical tests of Section 5, I use the growth of stock market capitalization as a proxy for stock market scandals that reduce the public's confidence in the stock market, since direct data on scandals are unavailable.

\section{Hypothesis 6}

Countries that experience highly publicized insider trading scandals tend to enact/enforce insider trading legislation in order to prevent loss of investor confidence, or worse, destabilizing political "backlash".

\section{Data and Stylized Facts}

\section{A. Data Sources}

Bhattacharya and Daouk (2000) compile a list of all countries known to have stock markets and the years in which the insider trading law, if one exists, was first passed and first enforced. I use this information to construct measures of the timing of enactment and enforcement of insider trading legislation. For most of the financial variables, I use the Database on Financial Development and Structure compiled by Beck, Demirguc-Kunt, and Levine (1999). ${ }^{45}$ I use their measure of stock market capitalization relative to gross domestic product as a measure of the size of the stock market across countries and time. I also use two of their measures of stock market liquidity: the total value traded relative to gross domestic product and the turnover ratio (total value traded divided by stock market capitalization). As another measure of stock market development, I use the number of listed domestic companies from the World Bank's Global Development Indicators and the International Finance Corporation's (IFC)

\footnotetext{
${ }^{44}$ Coffee (2000), pp. 22-23.

${ }^{45}$ This database can be downloaded from the World Bank website.
} 
Emerging Markets Factbook. As a measure stock market openness, I use data on foreign portfolio investment from the World Bank's Global Development Indicators. ${ }^{46}$

For legal origins, I rely mainly on the categorizations of $\operatorname{LLSV}(1997,1998)$. LLSV classify countries into four legal categories: English common law, French civil law, German civil law or Scandinavian civil law. I fill in the gaps with the CIA's classification of legal systems around the world.

Beck, Clarke, Groff, Keefer, and Walsh (1999) have assembled the Database of Political Institutions. Their variables, compiled for 177 countries over 21 years (19751995), include measures of the competitiveness of the political process as well as political ideology. I use three of their measures of the competitiveness of the political process. The first measure is a Herfindahl index of government concentration, the sum of the squared seat shares of all government and opposition parties in the legislature. The index is assigned a missing value if there is no parliament. A larger value means greater concentration (less competition) in the legislature, while a lower value signifies less concentration (greater competition). The second measure, fractionalization of the legislature, measures the probability that two officers chosen from the legislature at random are from different political parties. A higher value signifies that more political actors are "willing to act independently in the consideration of any given policy change," suggesting a more competitive legislature, and a lower value signifies a less competitive legislature. ${ }^{47}$ The fractionalization measure is assigned a missing value if there is no parliament. Beck, Demirguc-Kunt, and Levine (1999) also provide four measures of

\footnotetext{
${ }^{46}$ The World Bank defines net portfolio investment flows as "non-debt-creating portfolio equity flows (the sum of country funds, depository receipts, and direct purchases of shares by foreign investors) and portfolio debt flows (bond issues purchased by foreign investors)."

${ }^{47}$ Beck, Clarke, Groff, Keefer, and Levine (1999), p. 18
} 
political checks and balances that take into consideration both the number of pivotal decision makers (i.e., those "whose agreement is necessary before policies can be changed" ${ }^{, 48}$ ) and "the effectiveness of electoral checks on government decision makers." I use the average value of these four measures of political checks and balances. A higher value means more political checks and balances, increasing the likelihood of a change in the status quo; a lower value signifies fewer checks and balances, reducing the likelihood of a change in the status quo.

Beck, Demirguc-Kunt, and Levine (1999) also provide information on the political orientation of the government. I use two of their ideology variables. The first is the political ideology of the largest government party: left, center, or right. The second is the political orientation of the absolute majority in the houses that have lawmaking powers, if that majority is the party of the executive.

As proxies for "good government," I use two instruments: corruption and religious affiliation. ${ }^{50}$ An index of the level of corruption in the government comes from Mauro (1995). It takes on the values 0 to 10. A lower value signifies that senior and lower level government officials are likely to receive illegal payments, while a higher value signifies less government corruption. Data on religious affiliation of the population come from LLSV (1999a). The population of each country is divided into four religious groups: Roman Catholic, Muslim, Protestant, and "other religions". The values are expressed in percentage terms ( 0 to $100 \%$ for each religious category).

\footnotetext{
${ }^{48}$ Beck, Clarke, Groff, Keefer, and Levine (1999), p. 21.

${ }^{49}$ Beck, Clarke, Groff, Keefer, and Levine (1999), p. 25. Their measures "count the number of veto players in a political system, adjusting for whether these veto players are independent of each other, as determined by the level of electoral competitiveness in a system, their respective party affiliations, and the electoral rules." Id. at 26.

${ }^{50}$ LLSV (1999a) show that good governments tend to be less corrupt and their citizens more Protestant (as opposed to Catholic, Muslim and other religions).
} 
Finally, in the regression analysis, I control for official liberalization, to account for the possibility that insider trading legislation or enforcement is part of a broader effort to reform the stock market, rather than an isolated event. Information on the year of each country's official liberalization, if available, comes from Bekaert, Harvery, and Lundblad (2001).

\section{B. Stylized Facts}

Table 1 describes the historical development of international stock markets up to 1999. For each of the 103 countries reported, Table 1 presents the year of establishment of the country's main stock exchange, the year (if any) in which the country's insider trading law was enacted, the year (if any) in which the law was first enforced, and the year in which the country's stock market was officially liberalized. ${ }^{51}$ Table 1 illustrates that countries have experienced very different historical development of their stock markets and insider trading regulations. For example, the oldest stock exchange was established in Germany in 1585 . The youngest exchange was established as recently as 1997 in Kazakhstan. The earliest insider trading law was passed as early as 1934 in the United States. Some countries like Bulgaria, Swaziland and Kuwait, among others, have yet to regulate insider trading. Table 1 also indicates that the first incidence of enforcement occurred in 1961 in the United States, while the two most recent took place in Spain and Oman, in 1998 and 1999, respectively. Insider trading laws have yet to be enforced in many countries, including the developed markets of Austria, Ireland, Luxembourg, and New Zealand, among others, and the emerging markets of Mexico, Russia, and others. 
In addition, Table 1 shows that the stock markets of the developed countries are older than the stock markets of the developing countries, with mean establishment dates of 1828 and 1933, respectively. The developed stock markets also tend to have officially liberalized before the emerging markets (roughly 1982 versus 1991). However, the calendar years of enactment and enforcement of insider trading laws are roughly similar between developed and emerging stock markets. This implies that emerging stock markets enact insider trading laws when their stock markets are relatively younger. In fact, Table 1 shows that for emerging markets the average years of official liberalization and enactment of insider trading legislation are identical (i.e., 1991). ${ }^{52}$

Table 2 presents summary statistics of the variables used in the analysis. Table 3 reports correlation coefficients between the year insider trading legislation was enacted or enforced and the explanatory variables. ${ }^{53}$ Countries that enact insider trading legislation earlier tend to enforce them earlier as well. Countries whose stock exchanges are older do not enact/enforce insider trading legislation significantly earlier than those with younger stock markets. The size of the stock market (as measured by market capitalization relative to GDP and number of listed companies) is positively correlated with earlier insider trading legislation and enforcement. Common law countries tend to pass insider trading legislation earlier than civil law countries, but to enforce the laws later. French civil law countries both pass and enforce insider trading laws later. While German civil law countries pass insider trading legislation later, they enforce them

\footnotetext{
${ }^{51}$ Some of the 103 countries are excluded from the empirical analyses in Section 5, either because they do not satisfy the selection criteria (due to data availability) or because they do not have enough explanatory variables. These issues are discussed in more detail in Section 5.

${ }^{52}$ This is not the case at the country level, however. Emerging markets tend to liberalize after passing insider trading legislation.

${ }^{53}$ The results are qualitatively similar if I substitute year of enactment and enforcement with indicator variables of whether the law exists and has been enforced, respectively.
} 
earlier. Scadinavian civil law countries both enact and enforce insider laws earlier. The correlation coefficients between the political process variables and the year of passage/enforcement of insider trading law are of the expected signs. In particular, countries with more open political systems generally pass and enforce insider trading laws earlier than countries with less open political systems. Left-leaning countries tend to pass and enforce insider trading laws later, consistent with Roe (1999). Finally, countries with greater proportions of Catholics and Muslims tend to enact and enforce insider trading laws later than countries with larger Protestant (and other religions) populaces.

Table 4 reports coefficients of correlation between the financial and legal variables. All of the measures of stock market development are positively and significantly correlated with each other. Common law countries tend to have larger stock markets, but not older ones. In addition, they are not more liquid, based on turnover and value traded relative to GDP. French civil law countries tend to have younger, smaller and less liquid stock markets, while German civil law countries tend to have older, larger and more liquid stock markets. Scandinavian civil law countries tend to have fewer listed companies, but otherwise Scandinavian legal origin is not significantly correlated with the measures of financial development. The results in Table 4 are broadly consistent with those of $\operatorname{LLSV}(1997,1998)$.

Table 5 presents correlation coefficients between the financial, government, ideology and institutional variables. More open political systems tend to have larger and more liquid stock markets. They are also more likely to have officially liberalized their markets. Left-leaning systems tend to have smaller and less liquid stock markets, while 
right-leaning systems tend to have larger and more liquid stock markets. This finding is consistent with Roe's (2000) political theory of stock market development. It is also consistent with LLSV (1999b).

In the next section, I use multivariable duration analysis to test the hypotheses presented in section 3 .

\section{Empirical Methodology and Results}

\section{A. Duration Analysis}

I use duration analysis to estimate the timing of insider trading legislation and enforcement across countries. ${ }^{54}$ In duration or survival analysis the hazard rate, $h(t)$, is the probability that an event occurs at a particular time, $t$, given that it has not already occurred. In this study, I am interested in two separate hazard rates: (1) the probability that an insider trading law is passed in year $t$, given that it has not yet been passed and (2) the probability that the law, if one exists, is enforced during year $t$, given that it has not already been enforced.

The Kaplan-Meier estimator is a straightforward, nonparametric method for estimating the shape of the hazard function (the probability that the law is passed/enforced) as a function of time. Figures 1 and 2 depict graphs of the KaplanMeier product-limit estimator of the hazard functions for the enactment and enforcement of the law, respectively, over time. The hazard functions depicted in Figures 1 and 2 demonstrate that the hazard functions are relatively flat at first and then become steeper in later years, signifying an increasing hazard rate over time.

\footnotetext{
${ }^{54}$ See Kalbfleisch and Prentice (1980), Keifer (1988), and Greene (1997) for analytical methods for survival time data.
} 
The Weibull proportional hazards model is appropriate for estimating hazard functions that have this kind of shape. ${ }^{55}$ The hazard function has the following form:

$$
h[t, \mathrm{x}(t), \mathrm{b}]=h_{o}(t) \exp \left[\mathrm{x}(t)^{\prime} \mathrm{b}\right]
$$

where $h(t)$ is the hazard rate at time $t, \mathbf{b}$ is a vector of maximum-likelihood regression coefficients to be estimated by the model, $\mathbf{x}$ is a vector of independent or explanatory variables, and $h_{o}(t)$ is the baseline hazard rate. The baseline hazard rate, $h_{o}(t)$, equals

$p t^{p-1}$, where $p$ is a parameter estimated from the data. When $p>1$, the hazard rate (probability of law or enforcement) is monotonically increasing, as is the case in all of the regressions reported below and depicted in Figures 1 and 2. The parameters are estimated by maximum likelihood estimation. ${ }^{56}$ I assume that the time until regulation/enforcement is independent across countries, but that the observations of the same country over time are not independent.

An advantage of the Weibull model is that it enables calculation of the change in the expected time to the event in question for a given change in the independent variables. In particular, the log of the time to enactment/enforcement of insider trading law is a linear function of the explanatory variables and an error term:

$$
\ln (T)=x^{\prime} b+e
$$

where $T$ is the time until insider trading regulation/enforcement and the $b$ coefficients signify the percentage change in the time until regulation/enforcement for a one-unit change in the explanatory variables. Positive (negative) $b$ implies that an increase in the

\footnotetext{
55 Imposing the Weibull structure yields substantially similar results to the non-parametric Cox model, but has the interpretive advantages discussed below.

${ }^{56}$ See Kiefer (1988).
} 
explanatory variable increases (decreases) the expected time until regulation/enforcement of insider trading law.

\section{B. Results}

In Section 3, I presented several testable hypotheses about the relative timing of countries' enactment and enforcement of insider trading legislation. The general prediction (Hypotheses 1-5) is that insider systems are latecomers to the insider trading prohibition relative to arm's length/outsider systems. Stock market scandals (Hypothesis 6) provide an additional stimulus, under either system. The empirical approach is dynamic in that it permits countries to evolve from one type of system to the other over time. $^{57}$

\section{Enactment of Insider Trading Legislation}

The period from 1980 until the law is passed is the time (duration) until regulation. The duration analysis is based on a subset of the 103 countries in Table 1 , i.e., those that did not have insider trading laws prior to 1980. Thus, the analysis excludes the United States, Canada, France and a few other countries. In addition, I lose several countries (e.g., Bostwana, Iran, Zimbabwe and others) in the empirical analysis due to censoring because they did not enact insider trading laws between 1980 and 1997. Further observations are lost in the empirical analysis because I do not have information on all variables for all countries and years. Each regression reports the number of observations under consideration. I calculate standard errors using a robust estimation

\footnotetext{
${ }^{57}$ Empirically, the evolution tends to be a transition from an insider system to an outsider system. See Markus Berndt (2000) for theoretical support for this observation.
} 
procedure. ${ }^{58}$ To reduce the influence of outliers, I cap all of the explanatory variables at the $5^{\text {th }}$ and $9^{\text {th }}$ percentiles.

\section{a) Financial Factors}

Weibull regressions for the financial factors are reported in Panel A of Table 6. Having a larger stock market, as measured by stock market capitalization relative to GDP, significantly shortens the time until insider trading legislation is enacted (column 1). The coefficient is negative and significant at $10 \%$. This effect is unchanged when I control for official liberalization of the stock market (column 6). In fact, controlling for liberalization makes the coefficient both more negative and more significant. The number of listed companies is insignificant, with and without liberalization (columns 2, 7). Countries with greater foreign investment relative to market capitalization (i.e., more open capital markets) enact insider trading legislation sooner than less open markets (column 3). The coefficient on foreign investment is negative and significant at $1 \%$. However, after controlling for official liberalization, the coefficient on foreign investment becomes positive (column 8). A possible explanation for this result is that liberalization and foreign investment are strongly positively correlated. ${ }^{59}$ Countries with more liquid stock markets, as measured by turnover, enact insider trading legislation significantly earlier than less liquid markets, even after controlling for official liberalization (columns $4,9)$. The coefficient on turnover is negative and significant at $1 \%$ in both regressions. The coefficient on value traded relative to GDP is insignificant (columns 5, 10).

Consistent with the "backlash" thesis, each specification in Panel A of Table 6 demonstrates that countries are more likely to enact insider trading legislation after

\footnotetext{
${ }^{58}$ See Lin and Wei (1989)
} 
periods of negative growth, as measured by the 1- and 3-year rates of growth of stock market capitalization relative to GDP. The coefficients on the growth measures are positive and significant. The coefficient on the indicator variable for official liberalization is generally negative and significant (columns 6-10), suggesting that insider trading legislation is part of a broader reform effort, rather than an isolated event.

\section{b) Legal Factors}

Panel A of Table 7 reports Weibull regressions for the legal determinants of enactment of insider trading laws. Column 1 shows that French civil law countries tend to enact insider trading laws later than common law countries. The coefficient on French civil law is positive and significant at $1 \%$. German and Scandinavian legal origins are insignificant in column 1. After I control for the financial variables in columns 2-6, French civil law origin becomes insignificant and the coefficient on Scandinavian origin becomes negative and significant. In columns 7-10, I control for official liberalization. Controlling for liberalization generally renders legal origin insignificant (columns 7-10)

\section{c) Political Factors}

Weibull regressions for the political factors are reported in Panels A1 and A2 of Table 8. Each model is reported horizontally. Panel A1 reports the results for the measures of political competition. Regressions 1-3 report the coefficients for the political competition variables without the financial and liberalization variables. The coefficient on the checks and balances variable is negative and significant at $10 \%$; the coefficient on the Herfindahl index of legislative concentration is positive and significant at 15\%; and

\footnotetext{
${ }^{59}$ See Table 5 and Bekaert, Harvey, and Lundblad (2001).
} 
the coefficient on legislative fractionalization is negative and significant at $10 \%$. Thus, consistent with Hypothesis 3, less competitive political systems enact insider trading legislation significantly later than more open political systems. Rows 4-18 control for the financial and liberalization factors. The coefficient on checks and balances remains negative and is significant in specifications 4-6. The coefficient on the Herfindahl index switches signs to negative and is only weakly significant (rows 9-13). The coefficient on legislative fractionalization is insignificant after controlling for the financial development and liberalization measures (rows 14-18).

Panel A2 reports the results for the measures of political ideology. Right-leaning governments tend to enact insider trading laws earlier than left-leaning governments (the excluded dummy), consistent with Hypothesis 4. However the coefficients on the measures of right orientation are insignificant, before and after controlling for liberalization and financial development (all rows). An interesting result is that countries with center-dominated legislatures tend to enact insider trading laws later than countries with left-dominated legislatures (rows 2, 8-12).

\section{d) Institutional Factors}

Panel A of Table 9 reports Weibull regressions for the institutional determinants of enactment of insider trading laws. Each model is reported horizontally. There is only weak support for Hypothesis 5 that less corrupt governments enact insider trading legislation sooner than more corrupt governments (rows 1-6). The results in rows 7-12 suggest that countries with greater proportions of Catholics and Muslims, especially Muslims, enact insider trading laws later than countries with larger percentages of Protestants and members of other religions. This is consistent with Hypothesis 5. 


\section{Enforcement of Insider Trading Legislation}

The time between the year in which the law was enacted (or 1980, whichever is later) and the year the law was first enforced is the time (duration) until enforcement. The enforcement sample excludes countries that have not have enacted insider trading laws between 1980 and 1997. It also excludes (censors) countries (e.g., Bangladesh, Ireland, Kuwait and others) that did not enforce their insider trading laws during this period. Further observations are lost due to missing values of some variables for some countries and years. As before, each regression reports the number of observation in the analysis, standard errors are calculated using a robust estimation procedure, and all of the explanatory variables are capped at the $5^{\text {th }}$ and $9^{\text {th }}$ percentiles to reduce the influence of outliers.

\section{a) Financial Factors}

Weibull regressions on the financial factors are reported in Panel B of Table 6. Having a larger (measured by market capitalization and number of listed companies), more liquid (measured by turnover and value traded relative to GDP) and more open (measured by foreign investment relative to market capitalization) stock market significantly shortens the time between enacting and enforcing insider trading laws (columns 1-5). These results do not change when I control for official liberalization of the stock market (columns 6-10). In fact, official liberalization is always insignificant in the enforcement models; therefore, I exclude it in the regressions below. Consistent with the "backlash" thesis, each of the regressions demonstrates that countries are more likely to enforce their insider trading laws after periods of negative growth (measured by the 1- 
and 3-year rates of growth of stock market capitalization relative to GDP). The coefficients on the growth measures are generally positive and significant.

\section{b) Legal Factors}

Panel B of Table 7 presents the results of Weibull regressions on the legal variables. Column 1 presents the legal variables alone. The coefficients on the French, German and Scandinavian civil law dummies are negative; however, only the coefficient on German civil law is significant in column 1. In columns 2-6, I add the financial variables to the legal variables. The "backlash" factors remain significant after controlling for legal origin, i.e., negative market growth hastens enforcement of insider trading legislation, regardless of legal origin. Market capitalization becomes insignificant when I control for legal origin, but having a larger number of listed companies is still associated with earlier enforcement of insider trading laws (the coefficient is negative and significant at the $1 \%$ level). Open markets (measured by foreign investment relative to market capitalization) enforce insider trading laws sooner after enacting them (the coefficient is negative and significant at $1 \%$ ). Similarly, more liquid stock markets experience enforcement in a shorter span of time. The coefficient on turnover is negative and significant at $1 \%$ and the coefficient on value traded is negative and significant at $5 \%$.

After controlling for the financial variables, German and Scandinavian civil law countries tend to enforce their insider trading laws sooner (relative to enactment) than English common law countries. (One exception to this is column 2, in which the coefficient on German civil origin is positive and significant at $1 \%$ when controlling for stock market capitalization.) A possible explanation for this paradoxical result (i.e., that 
German and Scandinavian countries tend to enforce their laws earlier than common law countries) is that they tend to have less corrupt and better governments, and strong rule of law traditions.

\section{c) Political Factors}

Weibull regressions on the political openness and ideological variables are reported in Panels B1 and B2 of Table 8. Each model is reported horizontally. Panel B1 reports the results for the measures of political competition. Regressions 1-3 report the coefficients for the political competition variables without the financial variables. Consistent with Hypothesis 3, more open/competitive political systems enforce their insider trading laws in a relatively shorter time span after enactment. The coefficient on the checks and balances variable is negative and significant at 5\%; the coefficient on the Herfindahl index of legislative concentration is positive and significant at $10 \%$; and the coefficient on legislative fractionalization is negative and significant at $10 \%$. Panel B2 reports the results for the measures of political ideology. Right-leaning governments tend to enforce insider trading laws earlier, relative to their enactment, than left-leaning governments (rows 1 and 2 of Panel B2). This result is consistent with Hypothesis 4.

When I control for the financial variables in Panels B1 and B2, the political and ideological results are largely qualitatively similar. In fact, in some cases, the political variables overcome the financial variables. For example, in rows 4-6 of Panel B2, the coefficients on political checks and balances are negative and significant, while the coefficients on the financial variables (market capitalization, number of listed companies and foreign investment) are insignificant. In addition, in row 9, the coefficient on the Herfindahl index of legislative concentration is positive and significant at the $1 \%$ level, 
while the coefficient on stock market capitalization is insignificant. In row 14, the coefficient on fractionalization of the legislature is negative and significant, signifying a shorter duration to enforcement in countries with more competitive legislatures, while the coefficient on stock market capitalization is insignificant.

\section{d) Institutional Factors}

Panel B of Table 9 reports Weibull regressions for the institutional determinants of enforcement of insider trading laws. Each model is reported horizontally. Less corrupt countries enforce their insider trading laws sooner after passage than more corrupt countries; the coefficient is negative and significant at $10 \%$ (row 1). The qualitative effect of corruption is not changed by controlling for finance factors, although the coefficient becomes insignificant in a few of the specifications (see rows 2-6). In particular, the corruption result is overcome by market capitalization (row 2) and number of listed companies (row 3). The religion indicators of government quality are generally insignificant (rows 7-12).

C. Robust Analysis

I run the same sets of regressions without the censored observations (i.e., countries that did not enact or enforce insider trading legislation in the two respective samples). The results are qualitatively similar. Thus, there is no censoring bias. In addition, I run the same sets of regressions excluding countries whose stock markets were established after 1975. Again, the results are qualitatively similar. Finally, I run random effects logit regressions and the results are similar to those of the duration analysis. 


\section{Summary and Conclusions}

The paper's findings generally support the prediction that "outsider" systems tend to enact and/or enforce insider trading laws relatively earlier than "insider" systems, controlling for the age and the level of development of the stock market. I find that larger and more liquid stock markets are more likely to enact and enforce insider trading laws. This result is consistent with both private (distributional) and public (efficiency) rationales for why insider trading is a more contentious issue in large and liquid markets. In these markets, there are both greater opportunities for profitable insider trading by corporate insiders and their associates (tippees) and greater potential losses to liquidity traders and other outsiders who are harmed by greater transaction costs and/or higher agency costs. At the same time, as the market develops, outsiders opposed to insider trading are both more numerous and more influential. Thus, the private stakes increase as the stock market grows. In addition, the public stakes increase, since the potential social costs of insider trading are greater.

The evidence on legal determinants of enactment is weak. Legal origin does not have independent explanatory power in the regressions beyond its effect on financial development. The single exception is Scandinavian legal origin, but this result disappears after controlling for liberalization. In contrast, legal origin is relevant to the likelihood of enforcing insider trading legislation once it is in place. In particular, German and Scandinavian civil law countries tend to enforce their insider trading laws sooner (relative to enactment) than English common law countries, controlling for financial development. 
The results tend to support to the prediction that more competitive political systems enact insider trading laws sooner, even after controlling for financial development and liberalization. However, this result is not very strong. More open/competitive political systems also tend to enforce their insider trading laws in a relatively shorter time span after enactment, even after controlling for financial development. The ideological variables do not explain the timing of enactment of insider trading legislation. In particular, right- leaning governments do not enact insider trading laws earlier than left-leaning governments. However, right-leaning governments do tend to enforce the laws sooner, relative to their enactment, than left-leaning governments.

The results also generally support the notion that the quality of the government is an important factor in the timing of enactment and enforcement of insider trading laws. The enactment results (weakly) indicate that more corrupt governments are less likely to enact insider trading laws. Less corrupt countries also tend to enforce their insider trading laws sooner after their enforcement than more corrupt countries, even after controlling for the financial factors. In addition, I find that countries with greater proportions of Protestants enact insider trading laws sooner than countries with larger percentages of Catholics and Muslims, controlling for the level of financial development and liberalization. In contrast, religious affiliation is not significantly associated with the timing of enforcement of insider trading legislation.

I also find that countries are more likely to both enact and enforce insider trading legislation after periods of negative stock market growth, a proxy for the incidence of confidence-reducing stock market scandals. This result is consistent with Roe's (1998) "backlash" thesis. Finally, I find that countries tend to enact (but not to enforce) insider 
trading laws contemporaneously with official financial liberalization programs, implying that insider trading legislation is part of a larger package of stock market reforms.

Besides the insider trading debate, the results of this paper are relevant to several additional strands of the law and finance literature, especially to the question of convergence among financial systems. ${ }^{60}$ The evidence presented here suggests that countries are converging with respect to regulation of insider trading. However, as the results show, the rate of convergence depends upon economic, legal, political and institutional characteristics that are unique to each country.

${ }^{60}$ See, e.g., Coffee (1999, 2000, 2001) and Roe (2000). 


\section{References}

Amihud, Yakov and Haim Mendelson, 1986, Asset Pricing and the Bid-Ask Spread, 17 Journal of Financial Economics 223.

Barrett, David, ed., 1982, World Christian Encyclopedia: A Comparative Study of Churches and Religions in the Modern World, AD 1900-2000.

Bebchuk, Lucian and Christine Jolls, 1999, 15 Journal of Law, Economics and Organization.

Beck, Thorsten, George Clarke, Alberto Groff, Philip Keefer, and Patrick Walsh, 1999, New Tools and New Tests in Comparative Political Economy: The Database of Political Institutions.

Beck, Thorsten, Asli Demirguc-Kunt, and Ross Levine, 1999, Database on Financial Development and Structure.

Beck, Thorsten, Asli Demirguc-Kunt, and Ross Levine, 2001, Law, Politics, and Finance, unpublished working paper.

, 1999, A New Database on Financial Development and Structure.

Becker, Gary, 1983, A Theory of Competition Among Pressure Groups for Political Influence, 98 Quarterly Journal of Economics, 371-400.

Bekaert, Geert and Campbell Harvey, 2000, Foreign Speculators and Emerging Equity Markets, 55 Journal of Finance 565-614.

Bekaert, Geert, Campbell Harvey, and Christian Lundblad, 2001, Does Financial Liberalization Spur Growth, NBER Working Paper No. W8245.

Beny, Laura, 1999, A Comparative Empirical Investigation of Agency and Market Theories of Insider Trading, John M. Olin Discussion Paper No. 264.

, 2001a, A Comparative Empirical Investigation of Agency and Market Theories of Insider Trading, Unpublished Working Paper, available from author upon request. , 2001b, Do Shareholders Value Insider Trading Laws? International Evidence, John M. Olin Discussion Paper No. 345.

Berglof, Erik, 1997, A Note on the Typology of Financial Systems, in eds. Hopt, Klaus and Eddy Wymeersch, Comparative Corporate Governance: Essays and Materials 151. 
Berndt, Markus, 2000, Global Differences in Corporate Governance Systems: Theory and Implications for Reforms, John M. Olin Discussion Paper No. 303.

Bhattacharya, Utpal and Hazem Daouk, 2000, The World Price of Insider Trading, forthcoming Journal of Finance.

Bhide, Amar, 1993, The Hidden Costs of Stock Market Liquidity, 34 Journal of Financial Economics 31.

Bris, Arturo, 2000, Do Insider Trading Laws Work? Yale ICF Working Paper No. 00-19.

Business International Corporation, 1984.

Carlton, Dennis and Daniel Fischel, 1983, The Regulation of Insider Trading, 35 Stanford Law Review.

Central Intelligence Agency, 1996, CIA World Factbook (online). , 2000, CIA World Factbook (online).

Cheffins, Brian, 2001, Does Law Matter? The Separation of Ownership and Control in the United Kingdom, 30 Journal of Legal Studies 459-484.

Central Intelligence Agency, The World Factbook 2000.

Coffee, John, 1999, The Future as History: The Prospects for Global Convergence in Corporate Governance and Its Implications, 93 Northwestern University Law Review 641.

, 2000, Convergence and Its Critics: What are the Preconditions to the Separation of Ownership and Control? Columbia Law School Center for Law and Economic Studies Working Paper No. 170.

, 2001, The Rise of Dispersed Ownership: The Roles of Law and the State in the Separation of Ownership and Control, 111 Yale Law Journal 1.

Copeland, Thomas and Dan Galai, 1983, Information Effects and the Bid-Ask Spread, 38 Journal of Finance 1457.

Demsetz, Harold, 1967, Toward a Theory of Property Rights, 57 American Economic Review 347-359.

Demsetz, Harold, 1986, Corporate Control, Insider Trading and Rates of Return, 76 American Economic Review 313. 
Arturo Flores and Thomas Reynolds, Foreign Law: Current Sources of Basic Legislation in Jurisdictions of the World (1989). (See LLSV, 1998)

French, Kenneth and Richard Roll, 1986, Stock Return Variances: The Arrival of Information and the Reaction of Traders, 17 Journal of Financial Economics 5.

Georgakopoulous, Nicholas, 1993, Insider Trading as a Transactional Cost: A Market Microstructure Justification and Optimization of Insider Trading Regulation, 26 Connecticut Law Review 1.

Glosten, Lawrence and Lawrence Harris, 1988, Estimating the Components of the Bid/Ask Spread, 21 Journal of Financial Economics 123.

Goshen, Zohar and Gideon Parchomovsky, 2000, On Insider Trading Markets, and 'Negative' Property Rights in Information, Fordham Law and Economics Research Paper No. 06.

Greene, William, 1997, Econometric Analysis.

Grossman, Sanford, 1976, On the Efficiency of Competitive Stock Markets Where Traders Have Diverse Information, 31 Journal of Finance 573

Haddock, David and Jonathan Macey, 1986, Controlling Insider Trading in Europe and America: The Economics of the Politics, in eds. J.-Matthias Graf von den Schulenburg and Goran Skogh, Law and Economics and the Economics of Legal Regulation 149.

, 1987a, Regulation on Demand: A Private Interest Model, with an Application to Insider Trading Regulation, 30 Journal of Law and Economics 311-352.

, 1987b, A Coasian Model of Insider Trading, 80 Northwestern Law Review 14491472.

VII. International Finance Corporation, 1999, Emerging Markets Factbook CD-ROM.

International Financial Publications, London, UK, 1998, The Handbook of Stock, Derivative and Commodity Exchanges.

Jarrell, Gregg, 1984, Change at the Exchange: The Causes and Effects of Deregulation, 27 Journal of Law and Economics 273-307.

Jeng, Leslie, Andrew Metrick, and Richard Zeckhauser, 1999, The Profits to Insider Trading: A Performance-Evaluation Perspective, NBER Working Paper No. W6913. 
Johnson, Simon and Andrei Shleifer, 1999, Coase versus the Coasians: The Regulation and Development of Securities Markets in Poland and the Czech Republic, Harvard University

Kalbfleisch, J. and R. Prentice, 1980, The Statistical Analysis of Failure Time Data.

Kiefer, Nicholas, 1988, Economic Duration Data and Hazard Functions, 26 Journal of Economic Literature 646-679.

Kraakman, Reinier, 1991, The Legal Theory of Insider Trading Regulation in the United States, in Hopt, Klaus and Eddy Wymeersch, eds., European Insider Dealing 3955.

Kraweic, Kimberly, 2001, Fairness, Efficiency, and Insider Trading: Deconstructing the Coin of the Realm in the Information Age, 95 Northwestern University Law Review.

La Porta, Rafael, Florencio Lopes de Silanes, Andrei Shleifer, and Robert Vishny, 1999a, The Quality of Government, 15 Journal of Law, Economics and Organization 222-279.

, 1999b, Investor Protection: Origins, Consequences, Reform, NBER Working Paper 7428.

, 1998, Law and Finance, 106 Journal of Political Economy 1113.

, 1997, Legal Determinants of External Finance, 52 Journal of Finance.

Lin, D. and L. Wei, 1989, The Robust Inference for the Cox Proportional Hazards Model, 84 Journal of the American Statistical Association 1074-1078.

Manne, Henry, 1966, Insider Trading and the Stock Market.

Manove, Michael, 1989, The Harm in Insider Trading and Informed Speculation, 104 Quarterly Journal of Economics.

Maug, Ernst, 2000, Insider Trading Legislation and Corporate Governance, HumboldtUniversitat $\mathrm{Zu}$ Berlin Discussion Papers in Business No. 5.

, 1998, Large Shareholders as Monitors: Is There a Trade-Off between Liquidity and Control? 53 Journal of Finance 65.

Mauro, Paolo, 1995, Corruption and Growth, 110 Quarterly Journal of Economics 681. 
Morck, Randall, Bernard Yeung and Wayne Yu, 2000, The Information Content of Stock Markets: Why Do Emerging Markets Have Synchronous Price Movements? 58 Journal of Financial Economics.

Olson, Mancur, 1965, The Logic of Collective Action.

Pagano, Marco and Paolo Volpin, 1999, The Political Economy of Corporate Governance, Center for Studies in Economics and Finance Working Paper No. 29.

Peltzman, Sam, 1976, Toward a More General Theory of Regulation, 19 Journal of Law and Economics 211.

Polinksy, Mitchell and Steven Shavell, 2001, Corruption and Optimal Law Enforcement, 81 Journal of Public Economics 1-24.

Posner, Richard, 1974, Theories of Economic Regulation, 5 Bell Journal of Economics and Management Science 335-365.

Rajan, Raghuram and Luigi Zingales, 2001, The Great Reversals: The Politics of Financial Development in the $20^{\text {th }}$ Century, NBER Working Paper No. W8178.

Roe, Mark, 2001, Rents and their Corporate Law Consequences, 53 Stanford Law Review. , 2000, Political Preconditions to Separating Ownership from Corporate Control, Columbia Law School Center for Law and Economic Studies Working Paper No. 155.

, 1998, Backlash, 98 Columbia Law Review.

Roll, Richard, 1988, $R^{2}$, 43 Journal of Finance 541.

Shin, Jhinyoung, 1996, The Optimal Regulation of Insider Trading, 5 Journal of Financial Intermediation 49.

Shleifer, Andrei and Robert Vishny, 1997, The Limits of Arbitrage, 52 Journal of Finance 35.

Statistical Abstract of the World, 1995.

Stigler, George, 1971, The Theory of Economic Regulation, 2 Bell Journal of Economics and Management Science 3-21.

Stoll, Hans, 1989, Inferring the Components of the Bid-Ask Spread: Theory and Empirical Evidence, 44 Journal of Finance 115. 
United Nations, 1995, Demographic Yearbook.

VIII. World Bank, 1999, Global Development Indicators CD-ROM.

Worldmark Encyclopedia of Nations, $8^{\text {th }}$ ed., 1995.

Wurgler, Jeffrey, 2000, Financial Markets and the Allocation of Capital, 58 Journal of Financial Economics 187-214. 


\section{Appendix 1: A Model of Competition over Insider Trading Policy}

This model of the market for insider trading regulation is based on Becker's (1983) classic model of interest group competition. As in Becker's model, the model presented here incorporates both private (distributional) and public (efficiency) considerations. There are three parties: "insiders", "outsiders" and the regulator. "Insiders" and "outsiders" compete for political influence over the regulator, who determines the legal status of insider trading and the sanctions for violating the law, as well as enforcement policy. The ensuing competition generates an equilibrium outcome in the "market" for insider trading regulation.

1) The Market for Insider Trading Regulation

a) The Demand for Insider Trading Legislation

Any given insider trading regime tends to favor one party over the other. "Insiders" favor a lax insider trading policy, while "outsiders" favor a strict insider trading policy. If the law is strengthened, wealth is transferred from "insiders" to "outsiders", and vice versa. Each group's expenditures on political influence (lobbying, information campaigns, monetary bribes, etc.) are a function of the amount of wealth transferred to the group via the regulatory policy. Positive transfers generate support and negative transfers generate opposition. At the political equilibrium, each group maximizes its income by spending an optimal amount on political pressure, given the behavior of the competing group and the productivity of its own expenditures.

The insider trading policy, denoted $\alpha$, ranges from the most lax policy (i.e., minimal restrictions and sanctions, and lax enforcement) to the strictest policy (i.e., maximal restrictions and sanctions, and vigorous enforcement). The policy generates a level of "insider" and "outsider" rents, $\pi_{1}(\alpha)$ and $\pi_{0}(\alpha)$, respectively, with the properties $\pi_{I}^{\prime}(\alpha)<0, \pi_{I}^{\prime \prime}(\alpha)>0 ; \pi_{O}^{\prime}(\alpha)>0, \pi_{O}{ }^{\prime \prime}(\alpha)<0$; and $\pi_{I}^{\prime}(\alpha)=-\pi_{O}^{\prime}(\alpha)$. The policy, $\alpha$, transfers the amount $T_{i}$ to each group:

$$
\begin{aligned}
& T_{o}(\alpha)=\Pi_{o}(0)-\Pi o(\alpha) \\
& T_{I}(\alpha)=\Pi_{I}(0)-\Pi_{I}(\alpha),
\end{aligned}
$$

where $\prod_{i}(0)$ is the total rent of group $i$ when insider trading is not regulated, and $\prod_{i}(\alpha)$ is the total rent of group $i$ under the insider trading policy $\alpha$. Each group's political support $S_{i}(\alpha)$ is a function of the group's expenditures, $E_{i}$, which depend in turn on the regulatory transfer to the group, $T_{i}(\alpha)$ :

$$
S_{i}(\alpha)=S_{i}\left(E_{i}\right)=S_{i}\left[E_{i}\left(r_{i}, n_{i}, T_{i}(\alpha)\right]\right.
$$

where $r_{i}=n_{i} e_{\mathrm{i}}, n_{i}$ equals the number of members in group $i, e_{i}$ equals the expenditures per member of group $i$, and $n_{i}$ and $e_{i}$ are, for the time being, fixed.

b) The Supply of Insider Trading Legislation and Regulatory Equilibrium

The regulator chooses the policy, $\alpha^{*}$, that maximizes its total political support. That is, the regulator solves the following maximization problem:

$$
\operatorname{Max} \alpha[\operatorname{Si}(\alpha)+\operatorname{So}(\alpha)]
$$




$$
=\operatorname{Max} \alpha\left[\operatorname{Si}\left(\operatorname{Ei}_{\mathrm{i}}(\alpha)\right)+\operatorname{So}(\operatorname{Eo}(\alpha))\right]
$$

This yields the following first order condition:

$$
\frac{\partial E_{I}}{\partial \alpha} \cdot \frac{\partial S_{I}}{\partial E_{I}}=-\frac{\partial E_{o}}{\partial \alpha} \cdot \frac{\partial S_{o}}{\partial E_{O}}
$$

This first order condition implies that, at the regulatory equilibrium, the regulator maximizes its total political support by implementing the policy, $\alpha^{*}$, that equates "insiders" " marginal opposition and "outsiders"” marginal support. Graphically,

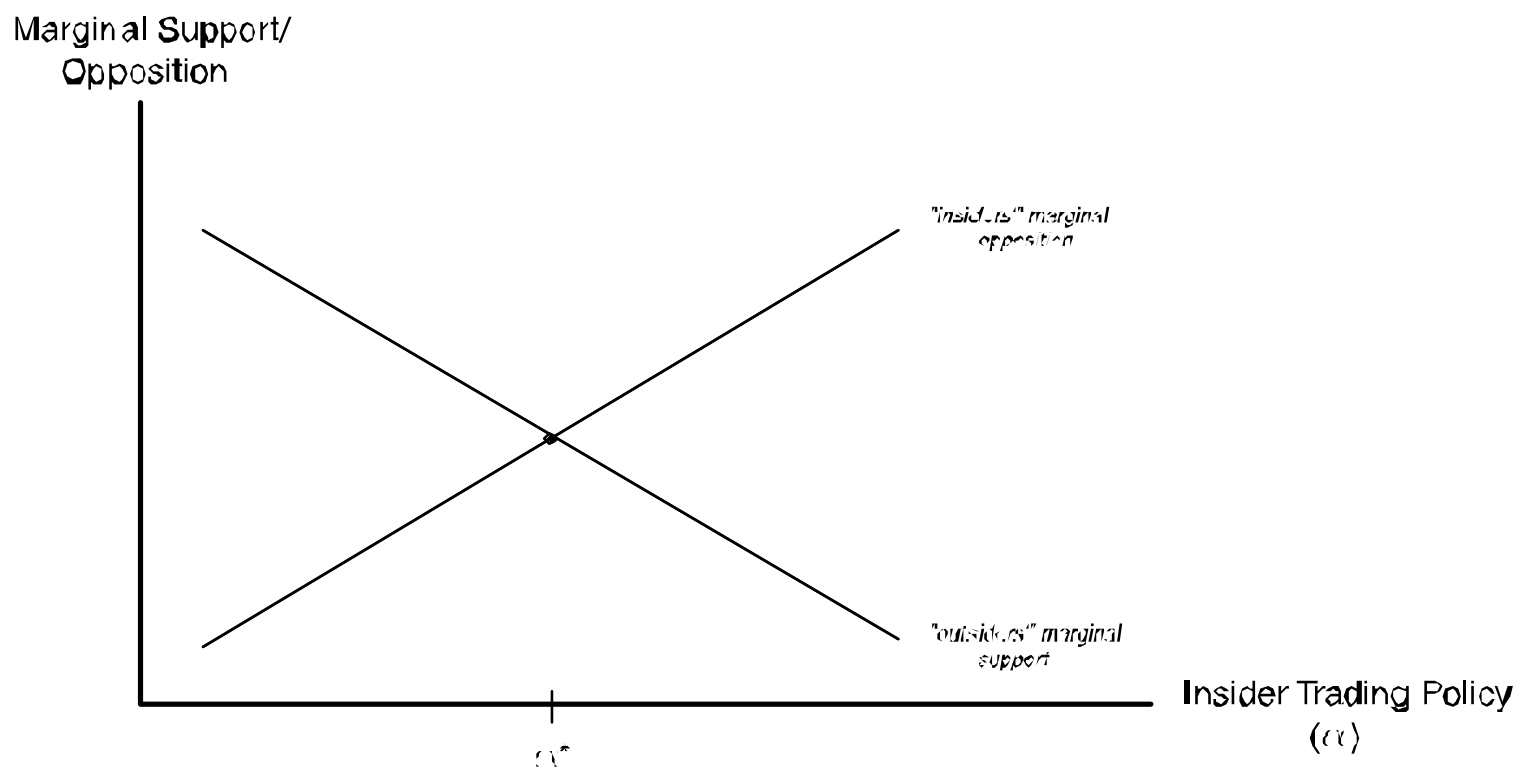

2) Comparative Statics

a) The Effect of a Change in the Size of a Constituency

A change in the size of one the competing constituencies changes the productivity of its expenditures on political influence. Recall the political support function

$$
S_{i}(\alpha)=S_{i}\left(E_{i}\right)=S_{i}\left[E_{i}\left(r_{i}, n_{i}, T_{i}(\alpha)\right]\right.
$$

Holding constant the amount transferred to each group, $T_{i}$, and expenditures per member, $e_{i}$, the effect of an increase in the number of members, $n_{i}$, on the marginal product of political expenditures is given by 


$$
\begin{gathered}
\left(\frac{\partial}{\partial n}\right)\left(\frac{\partial S(r, n)}{\partial r}\right)=\left(\frac{\partial}{\partial r}\right)\left(\frac{\partial S(r, n)}{\partial r}\right)\left(\frac{\partial r}{\partial n}\right)+\left(\frac{\partial}{\partial n}\right)\left(\frac{\partial S(r, n)}{\partial r}\right) \\
=e S_{r r}+S_{r n}
\end{gathered}
$$

The first component on the right hand side is the scale effect, which measures the change in the productivity of expenditures as expenditures increase. More members, holding constant the level of expenditures per member, means greater total expenditures on political pressure for any given policy. The scale effect can be either positive or negative. It is positive if expenditures exhibit increasing returns to scale, and negative if they exhibit decreasing return s to scale. The second component on the right hand side is the free riding effect. The free riding effect is unambiguously negative due to free riding, which arises because each member of the group has an incentive to do nothing and simply rely on the other members to expend resources toward the production of political pressure.

The net effect of an increase in the size of an interest group is ambiguous. However, if the group is sufficiently small, a modest increase in its size is likely to raise the marginal product of expenditures on political support, since free riding is better managed in small groups and because economies of scale are likely to be positive when expenditures are relatively low (Becker, 1983). Therefore, when a small group experiences a modest increase in its members, the marginal benefit due to a larger scale is likely to exceed the marginal cost due to more free riding, increasing the marginal productivity of expenditures. Eventually, as the group continues to expand, the marginal productivity of expenditures falls since free riding becomes unwieldy and diminishing returns to scale become more important (Becker, 1983).

More developed stock markets tend to have more numerous "outsider" constituencies. Thus, if the scale effect outweighs the free riding effect, the productivity of "outsiders" expenditures on political support increase as a country's stock market grows and becomes more liquid. A productivity enhancing increase in the number of "outsiders" opposed to insider trading is represented graphically as follows:

\section{Marginal Support/ \\ Opposition}

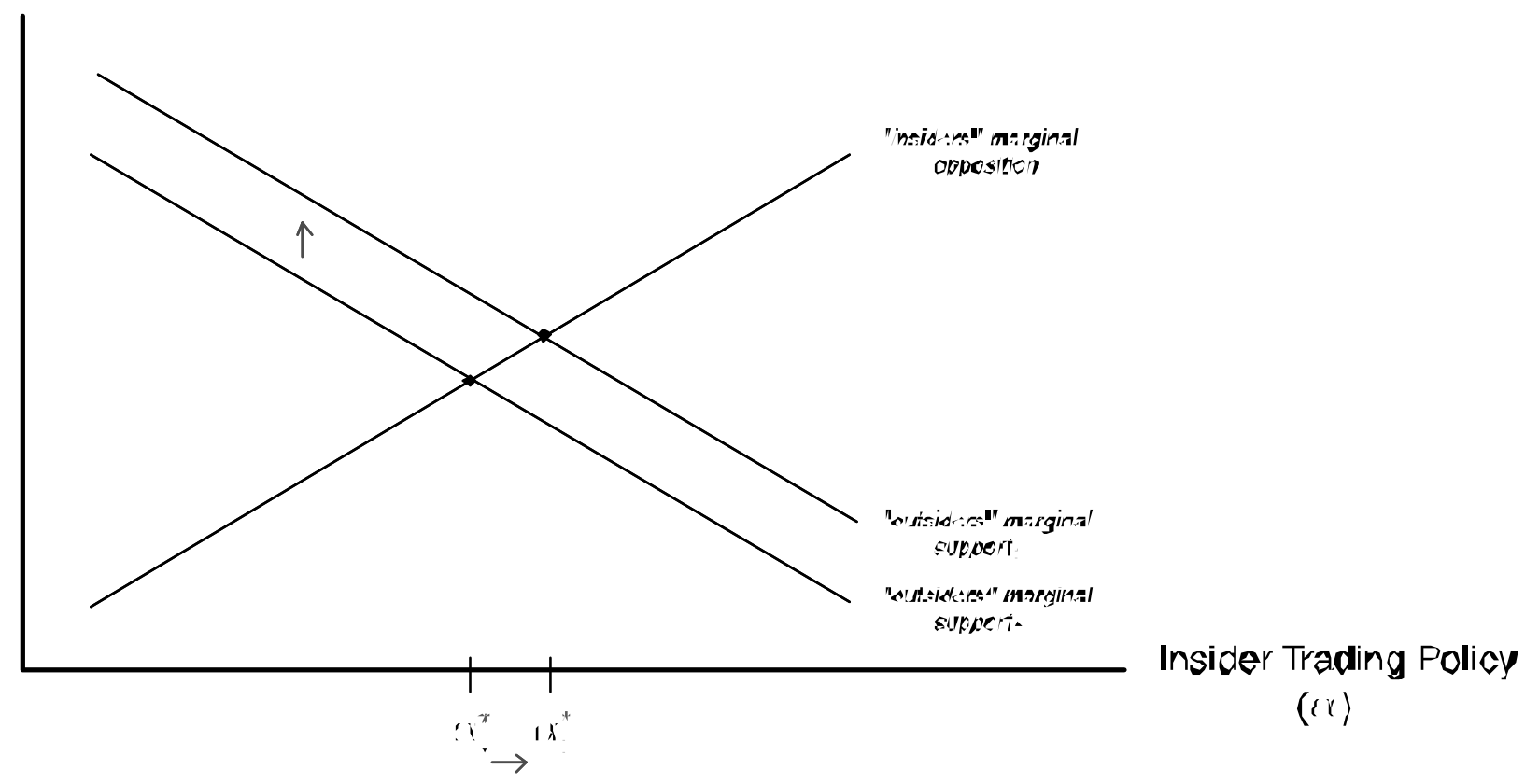


The marginal support curve shifts upward, resulting in a more restrictive equilibrium insider trading policy.

b) The Effect of a Change in the Productivity of Political Expenditures

An exogenous change in the "technology" of political support or opposition, i.e., a group's ability to translate its expenditures into political support or opposition changes the productivity of political expenditures. A group might become "more efficient at producing pressure, perhaps because of greater success at controlling free riding or at using television and other media." (Becker, 1983, p. 379). In the context of stock market regulations, for example, the emergence of investor advocacy groups might represent a "technological" advance that increases the productivity of expenditures on lobbying for more stringent insider trading rules and enforcement. These groups provide an important mechanism for the articulation of the interests of dispersed shareholders. Similarly, institutional investors might help to overcome free riding problems and thus increase the productivity of expenditures in support of stronger investor protections.

A "technological" advance increasing the productivity of support for insider trading regulation shifts the marginal support curve upward, implying greater support for regulatory intervention at any given policy level and hence a stricter equilibrium insider trading policy.

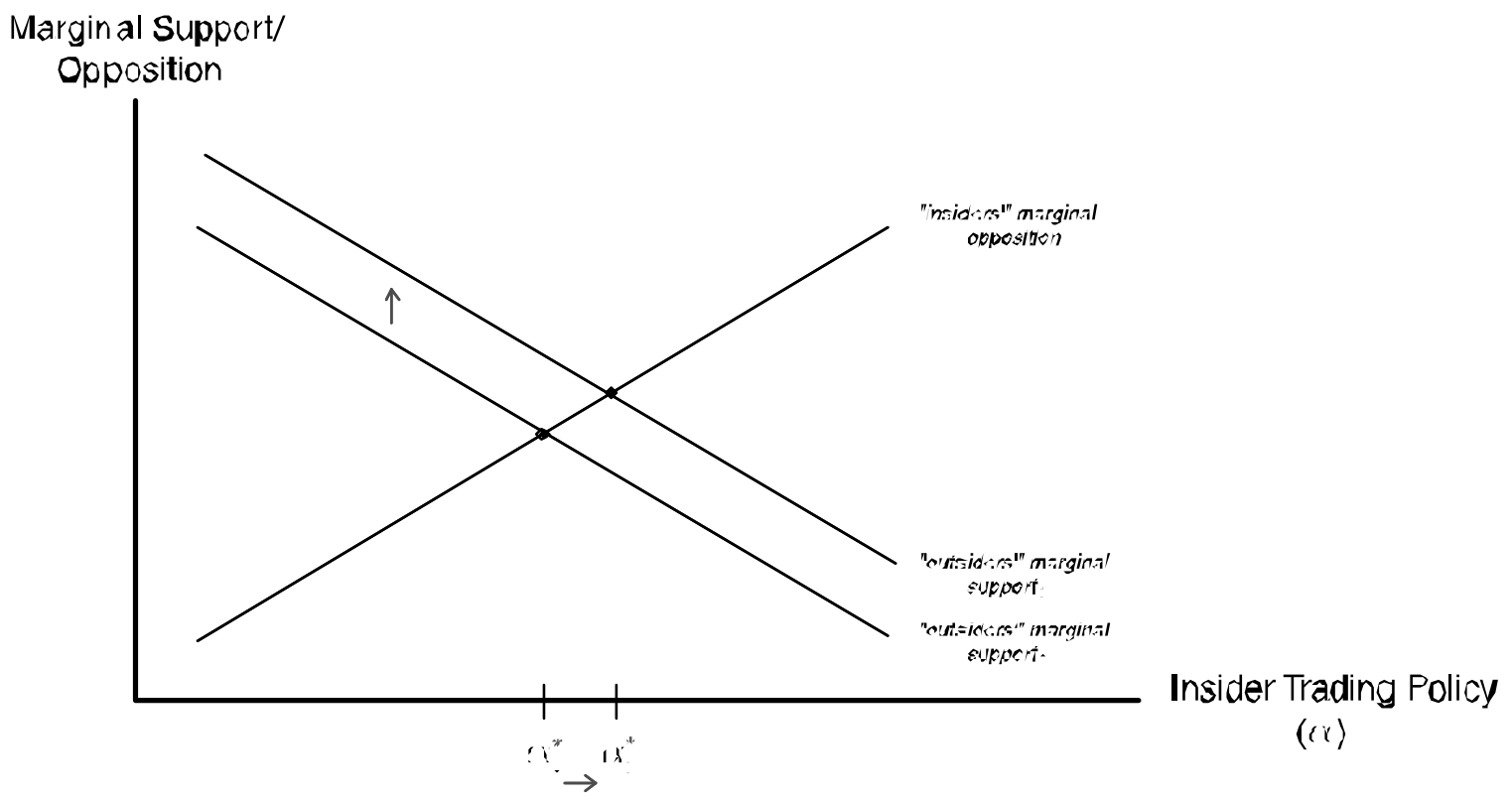

3) Incorporating the Public Interest

Many economic models of regulation consider private interests as the sole determinants of regulatory policy. However, Becker's (1983) model of interest group competition reconciles the public and private interest approaches. In Becker's model, an interest group has an inherent disadvantage in the competition for political influence if the policy that it favors is socially inefficient, i.e., if the social cost of its favored policy is greater than its social benefit. Opponents of a socially inefficient policy have an inherent advantage in challenging it. ${ }^{\mathrm{i}}$

If insider trading legislation raises social efficiency, "outsiders" have an inherent advantage in pushing for tougher insider trading laws and enforcement. This is represented graphically as a shift in "outsiders" support curve, resulting in a stricter equilibrium insider trading policy: 


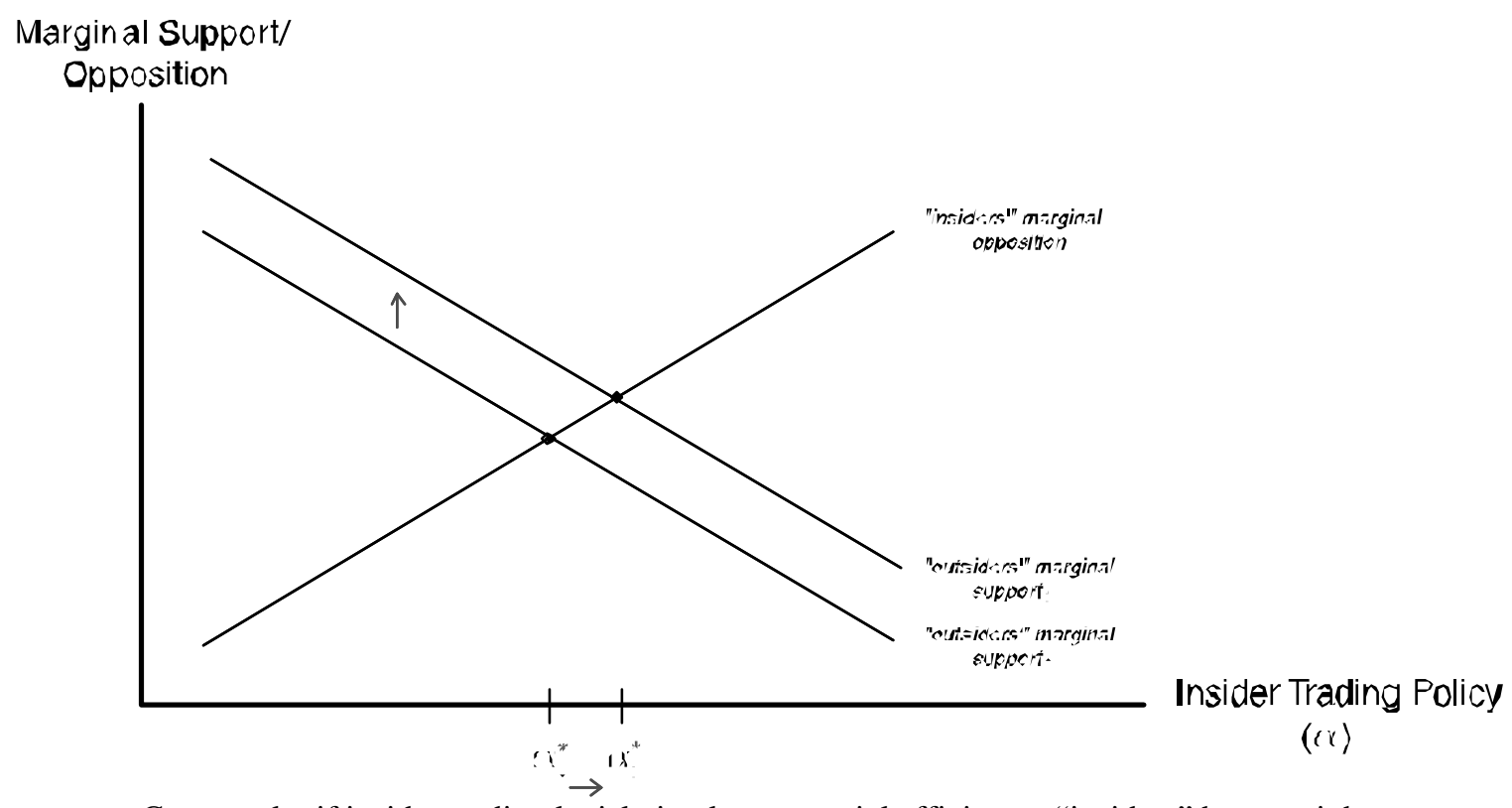

Conversely, if insider trading legislation lowers social efficiency, "insiders" have an inherent advantage in opposing tougher insider trading laws and enforcement. This is represented graphically as a shift in "insiders"” opposition curve, resulting in a more lenient equilibrium insider trading policy:

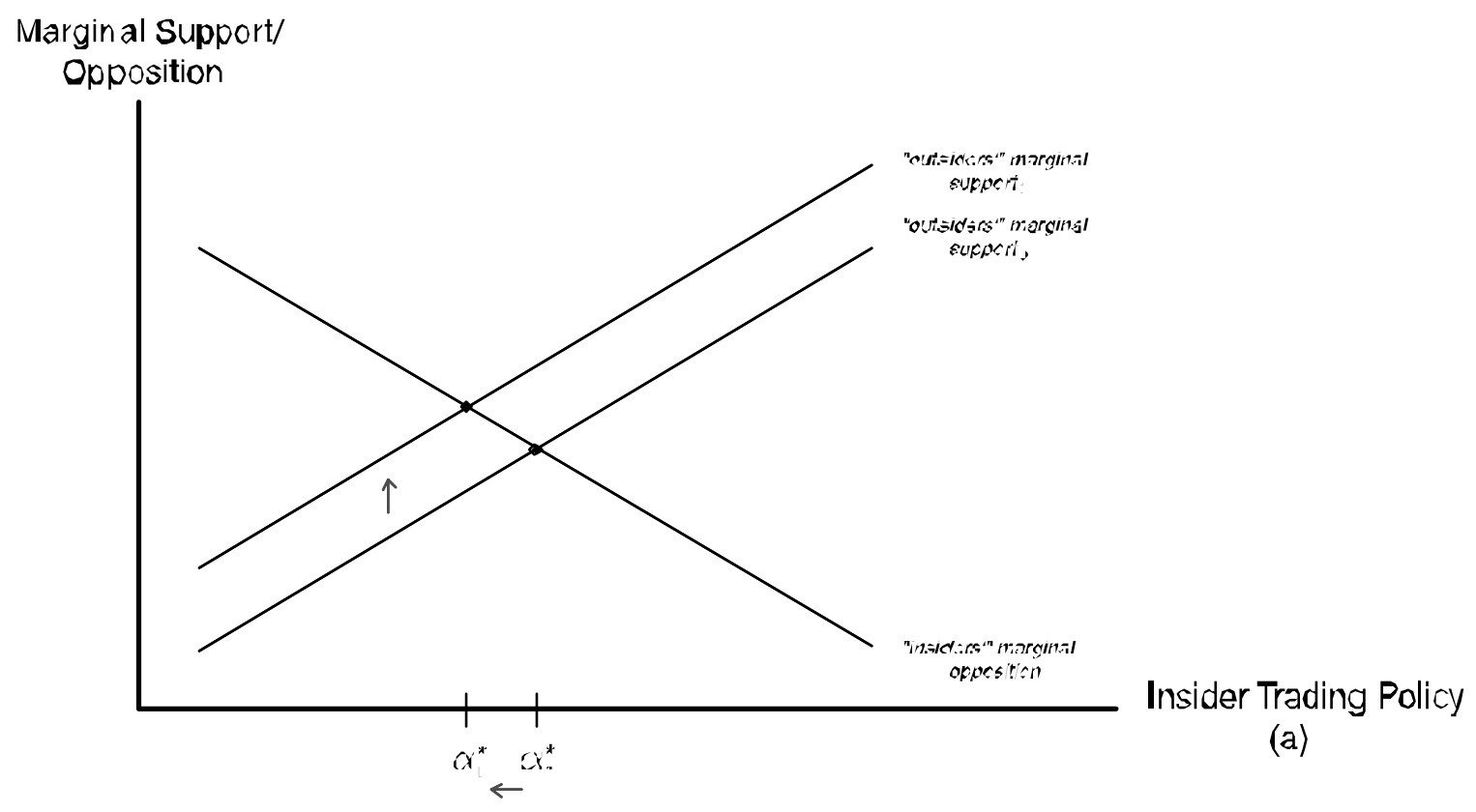


Appendix 2: Data Appendix

\section{Establishment of main stock exchange}

The year in which the country's main stock exc hange was established. Source:

Bhattacharya and Daouk (2000). Primary sources: International Financial Publications, The Handbook of Stock, Derivative and Commodity Exchanges (1998) or, if information is unavailable in the Handbook, the stock exchange websites.

\section{Year insider trading law passed}

The year in which the country passed its insider trading laws. Source: Bhattacharya and Daouk (2000). Primary sources: survey of stock exchanges and national regulators.

\section{Year law first enforced}

The year in which the country first enforced its insider trading laws. Source:

Bhattacharya and Daouk (2000). Primary sources: survey of stock exchanges and national regulators.

\section{Insider trading law}

A dummy variable that equals one if the country has an insider trading law in a given year, and zero otherwise. Source: Bhattacharya and Daouk (2000).

\section{Enforcement of insider trading law}

A dummy variable that equals 1 if the country's insider trading law has been enforced for the first time (i.e., at least once). Source: Bhattacharya and Daouk (2000). Primary Sources: national stock markets and regulators.

\section{Stock market capitalization relative to gross domestic product (GDP)}

Annual stock market capitalization divided by gross domestic product over the period 1980-1997. Source: Beck, Demirguc-Kunt, and Levine (1999).

\section{Number of listed companies}

Annual number of listed domestic companies over the years 1980-1997. Source: World Bank, Global Development Indicators CD-ROM (1999) and International Finance Corporation, Emerging Markets Factbook CD-ROM (1999).

\section{Foreign portfolio investment relative to stock market capitalization}

Annual net portfolio flows relative to stock market capitalization, where net portfolio flows are as defined above. Net portfolio flows relative to stock market capitalization are reported for the period 1980-1997, when available. Data on portfolio flows come from World Bank, Global Development Indicators CD-ROM (1999). Data on stock market capitalization come from Beck, Demirguc-Kunt, and Levine (1999).

\section{Stock market turnover}

Annual total value traded divided by stock market capitalization over the period 19801997. Source: Beck, Demirguc-Kunt, and Levine (1999). 


\section{Stock market total value traded relative to GDP}

Annual total value of shares traded on the stock exchange divided by GDP for the period 1980-1997. Source: Beck, Demirguc-Kunt, and Levine (1999).

\section{Official liberalization}

An indicator variable that equals one when the stock market has been officially liberalized, and zero otherwise. Official liberalization dates are derived from the chronology presented in Bekaert and Harvey (2000). Source: Bekaert, Harvey, and Lundblad (2001).

\section{One-year and three-year growth of stock market capitalization relative to GDP}

The one-year and three-year growth rate of stock market capitalization relative to GDP, calculated as the difference between stock market capitalization relative to GDP in years $t$ and $\mathrm{t}-1(\mathrm{t}-3)$ divided by stock market capitalization relative to GDP in year $\mathrm{t}-1(\mathrm{t}-$ 3). Source: Beck, Demirguc-Kunt, and Levine (1999).

\section{GDP per capita}

Annual per capita gross domestic product (GDP) for the years 1980-1997. Source: World Bank, Global Development Indicators CD-ROM (1999).

\section{Legal origin}

An indicator variable that signifies the country's legal origin. The variable equals 1 if the country's legal origin is English common law; 2 if it is French civil law; 3 if it is German civil law; and 4 if it is Scandinavian civil law. Source: LLSV (1998) and CIA (2000).

Primary source: Flores and Reynolds (1989).

\section{Herfindahl index of government concentration}

Degree of competition among government and opposition parties in the parliament. The Herfindahl index equals the sum of the squared seat shares of all government and opposition parties in the Parliament. A higher value signifies less competition (higher concentration) in the legislature and a lower value signifies greater competition (lower concentration). The index is computed annually for countries and years for which the information is available, and is assigned a value of missing if there is no parliament or information on seat shares is unavailable. I use the annual values over the period 19801995 for each country, when available. Source: Beck, Groff, Keefer, and Walsh (1999).

\section{Fractionalization of the legislature}

Fractionalization of the legislature measures the probability that two officers chosen at random from the legislature are members of different parties. Fractionalization equals missing if the country has no parliament. The variable is computed annually for countries and years for which the information is available. I use the annual values over the period 1980-1995 for each country, when available. Source: Beck, Groff, Keefer, and Walsh (1999).

Average checks and balances

The average value of the four measures of political checks and balances, constructed by Beck, Clarke, Groff, and Levine (1999). The measures incorporate both the number of 
decision- makers "whose agreement is necessary before policies can be changed" and "the effectiveness of electoral checks on government decision makers." The variable is computed annually for countries and years for which the information is available. I use the annual values over the period 1980-1995 for each country, when available. Source: Beck, Groff, Keefer, and Walsh (1999).

\section{Ideology of largest government party}

Left includes parties that are communist, socialist, social democratic, or left-wing. Center includes parties that are centrist or party's "position can best be described as centrist (e.g., party advocates strengthening private enterprise in a social-liberal context). Not described as centrist if competing parties 'average out' to a centrist position (e.g., party of 'right-wing Muslims and Beijing-oriented Marxists')." Right includes parties that are conservative, Christian democratic or right-wing. I use annual indictors of government ideology over the period 1980-1995 for each country, when available. Source: Beck, Groff, Keefer, and Walsh (1999).

\section{Ideology of majority party in the legislature}

The political orientation (Left, Center, or Right, as defined above) of the absolute majority in the houses that have lawmaking powers, if the legislative majority is the party of the executive. I use annual indictors of the majority ideology over the period 19801997 for each country, when available. Source: Beck, Groff, Keefer, and Walsh (1999).

\section{Corruption}

"The degree to which business transactions involve corruption or questionable payments." The index takes on the values 0 to 10 . A lower value signifies a higher degree of corruption or side payments in business dealings, while a higher value indicates less corruption or side payments in business transactions. The corruption index for a given country is the average over the period 1980-1983. Source: Mauro (1995). Primary source: Business International Corporation (1984).

\section{Religious affiliation}

Religious affiliation measures the proportion of the country's population belonging to the world's three largest religions in 1980, or over the period 1990-1995 for newly formed countries. Religious affiliation is expressed in percentage terms (0 to 100\%). The three major religions include: (1) Protestant; (2) Muslim; and (3) Roman Catholic. The remaining religions are classified as "other religions". Source: LLSV (1999a). Primary sources: Barrett (1982), Worldmark Encyclopedia of Nations (1995), Statistical Abstract of the World (1995), United Nations (1995), and CIA (1996). 
Table 1: Historical Development of International Stock Exchanges

\begin{tabular}{|c|c|c|c|c|}
\hline Country & $\begin{array}{l}\text { Year of Main } \\
\text { Exchange }\end{array}$ & $\begin{array}{l}\text { Year Insider Trading } \\
\text { Law Enacted }\end{array}$ & $\begin{array}{l}\text { Year of First } \\
\text { Enforcement }\end{array}$ & $\begin{array}{c}\text { Year of } \\
\text { Official } \\
\text { Liberalization }\end{array}$ \\
\hline \multicolumn{5}{|l|}{ Developed Countries } \\
\hline Australia & 1859 & 1991 & 1996 & 1980 \\
\hline Austria & 1771 & 1993 & None & 1980 \\
\hline Belgium & 1801 & 1990 & 1994 & Pre-1980 \\
\hline Canada & 1878 & 1966 & 1976 & 1980 \\
\hline Denmark & 1919 & 1991 & 1996 & 1980 \\
\hline Finland & 1912 & 1989 & 1993 & 1980 \\
\hline France & 1826 & 1967 & 1975 & 1980 \\
\hline Germany & 1585 & 1994 & 1995 & 1980 \\
\hline Hong Kong & 1891 & 1991 & 1994 & \\
\hline Ireland & 1793 & 1990 & None & 1980 \\
\hline Italy & 1806 & 1991 & 1996 & 1980 \\
\hline Japan & 1878 & 1988 & 1990 & 1983 \\
\hline Luxembourg & 1929 & 1991 & None & \\
\hline Netherlands & $1600 \mathrm{~s}$ & 1989 & 1994 & 1980 \\
\hline New Zealand & 1870 & 1988 & No & 1987 \\
\hline Norway & 1819 & 1985 & 1990 & 1980 \\
\hline Singapore & 1930 & 1973 & 1978 & 1980 \\
\hline Spain & 1831 & 1994 & 1998 & 1985 \\
\hline Sweden & 1863 & 1971 & 1990 & 1980 \\
\hline Switzerland & 1938 & 1988 & 1995 & 1980 \\
\hline United Kingdom & 1773 & 1980 & 1981 & 1980 \\
\hline United States & 1792 & 1934 & 1961 & 1980 \\
\hline Developing Average & 1828 & 1990 & 1994 & $<1982$ \\
\hline \multicolumn{5}{|l|}{ Emerging Markets } \\
\hline Argentina & 1854 & 1991 & 1995 & 1989 \\
\hline Armenia & 1993 & 1993 & None & \\
\hline Bahrain & 1987 & 1990 & None & \\
\hline Bangladesh & 1954 & 1995 & 1998 & None \\
\hline Barbados & 1987 & 1987 & None & None \\
\hline Bermuda & 1971 & None & None & \\
\hline Bolivia & 1979 & None & None & \\
\hline Botswana & 1989 & None & None & None \\
\hline Brazil & 1890 & 1976 & 1978 & 1971 \\
\hline Bulgaria & 1991 & None & None & \\
\hline Chile & 1893 & 1981 & 1996 & 1992 \\
\hline China & 1990 & 1993 & None & \\
\hline Colombia & 1928 & 1990 & None & 1991 \\
\hline Costa Rica & 1976 & 1990 & None & None \\
\hline Croatia & 1918 & 1995 & None & \\
\hline Cyprus & 1996 & 1999 & None & \\
\hline Czech Republic & 1871 & 1992 & 1993 & \\
\hline Ecuador & 1969 & 1993 & None & None \\
\hline Egypt & 1890 & 1992 & None & 1997 \\
\hline El Salvador & 1992 & None & None & None \\
\hline Estonia & 1996 & 1996 & None & \\
\hline Ghana & 1989 & 1993 & None & None \\
\hline Greece & 1876 & 1988 & 1996 & 1987 \\
\hline Guatemala & 1986 & 1996 & None & None \\
\hline Honduras & 1992 & 1988 & None & None \\
\hline Hungary & 1864 & 1994 & 1995 & \\
\hline Iceland & 1985 & 1989 & None & None \\
\hline India & 1875 & 1992 & 1998 & 1992 \\
\hline Indonesia & 1912 & 1991 & 1996 & 1989 \\
\hline Iran & 1966 & None & None & None \\
\hline Israel & 1953 & 1981 & 1989 & 1996 \\
\hline Jamaica & 1961 & 1993 & None & None \\
\hline Jordan & 1978 & None & None & 1995 \\
\hline Kazakhstan & 1997 & 1996 & None & \\
\hline Kenya & 1954 & 1989 & None & None \\
\hline Kuwait & 1984 & None & None & None \\
\hline Latvia & 1993 & None & None & \\
\hline
\end{tabular}


Table 1. Continued.

\begin{tabular}{|c|c|c|c|c|}
\hline Lebanon & 1920 & 1995 & None & \\
\hline Lithuania & 1926 & 1996 & None & \\
\hline Macedonia & 1996 & 1997 & None & \\
\hline Malawi & 1996 & None & None & None \\
\hline Malaysia & 1973 & 1973 & 1996 & 1988 \\
\hline Malta & 1992 & 1990 & None & None \\
\hline Mauritius & 1988 & 1988 & None & None \\
\hline Mexico & 1894 & 1975 & None & 1989 \\
\hline Moldova & 1994 & 1995 & None & \\
\hline Mongolia & 1991 & 1994 & None & \\
\hline Morocco & 1929 & 1993 & None & 1997 \\
\hline Namibia & 1992 & None & None & \\
\hline Nigeria & 1960 & 1979 & None & 1995 \\
\hline Oman & 1988 & 1989 & 1999 & None \\
\hline Pakistan & 1947 & 1995 & None & 1991 \\
\hline Palestine & 1995 & None & None & \\
\hline Panama & 1990 & 1996 & None & \\
\hline Paraguay & 1977 & 1999 & None & None \\
\hline Peru & 1951 & 1991 & 1994 & None \\
\hline Philippines & 1927 & 1982 & None & 1991 \\
\hline Poland & 1817 & 1991 & 1993 & \\
\hline Portugal & 1825 & 1986 & None & 1986 \\
\hline Romania & 1882 & 1995 & None & \\
\hline Russia & 1994 & 1996 & None & \\
\hline Saudi Arabia & 1984 & 1990 & None & None \\
\hline Slovakia & 1991 & 1992 & None & \\
\hline Slovenia & 1924 & 1994 & 1998 & \\
\hline South Africa & 1887 & 1989 & None & 1992 \\
\hline South Korea & 1956 & 1976 & 1988 & 1992 \\
\hline Sri Lanka & 1896 & 1987 & 1996 & 1992 \\
\hline Swaziland & 1990 & None & None & None \\
\hline Taiwan & 1961 & 1988 & 1989 & \\
\hline Tanzania & 1998 & 1994 & None & \\
\hline Thailand & 1974 & 1984 & 1993 & 1987 \\
\hline Trinidad & 1981 & 1981 & None & None \\
\hline Tunisia & 1969 & 1994 & None & None \\
\hline Turkey & 1866 & 1981 & 1996 & 1989 \\
\hline Ukraine & 1992 & None & None & \\
\hline Uruguay & 1867 & 1996 & None & None \\
\hline Uzbekistan & 1994 & None & None & \\
\hline Venezuela & 1840 & 1998 & None & 1990 \\
\hline Yugoslavia & 1894 & 1997 & None & \\
\hline Zambia & 1994 & 1993 & None & None \\
\hline Zimbabwe & 1896 & None & None & 1993 \\
\hline Emerging Average & 1933 & 1991 & 1995 & 1991 \\
\hline
\end{tabular}

Sources: Bhattacharya and Daouk (2000) for information on establishment of main stock exchange, year of enactment and enforcement of insider trading laws; Bekaert, Harvey and Lundblad (2001) for information on official liberalization dates.

Note: Blank entries signify that information regarding the country's official liberalization is unavailable. 
Table 2: Summary Statistics

\begin{tabular}{|c|c|c|c|c|c|c|}
\hline Variable & Mean & $\begin{array}{l}\text { Standard } \\
\text { Deviation }\end{array}$ & Median & Minimum & Maximum & No. of Obs \\
\hline Year Law Enacted & 1990.76 & 4.030 & 1991 & 1981 & 1999 & 1171 \\
\hline Year Law Enforced & 1994.49 & 2.651 & 1995 & 1989 & 1999 & 532 \\
\hline $\begin{array}{l}\text { Official Liberalization } \\
\text { Finance Variables }\end{array}$ & 1988 & 5.617 & 1989 & Pre-1980 & 1997 & 644 \\
\hline Age of Main Stock & & & & & & \\
\hline Exchange & 81.588 & 77.413 & 67 & 0 & 414 & 1345 \\
\hline $\begin{array}{l}\text { GDP per capita } \\
\text { Market }\end{array}$ & 7329.463 & 8643.186 & 2809.860 & 219.549 & $31,201.630$ & 1070 \\
\hline $\begin{array}{l}\text { Capitalization/GDP } \\
\text { Number of Listed }\end{array}$ & 0.226 & 0.252 & 0.136 & 0.0003 & 1.137 & 774 \\
\hline $\begin{array}{l}\text { Companies } \\
\text { Foreign Portfolio } \\
\text { Investment/Stock }\end{array}$ & 184.206 & 191.991 & 129 & 0 & 1089 & 763 \\
\hline Market Capitalization & 0.010 & 0.023 & 0.000 & -0.005 & 0.135 & 396 \\
\hline $\begin{array}{l}\text { Turnover Ratio } \\
\text { Value Traded Relative }\end{array}$ & 0.350 & 0.551 & 0.171 & 0.000 & 5.277 & 812 \\
\hline $\begin{array}{l}\text { to GDP } \\
\text { Growth of Market } \\
\text { Capitalization }\end{array}$ & 0.064 & 0.099 & 0.022 & 0.000 & 0.605 & 902 \\
\hline $\begin{array}{l}\text { (1 year) } \\
\text { Growth of Market } \\
\text { Capitalization }\end{array}$ & 0.141 & 0.851 & -0.081 & -0.996 & 3.351 & 576 \\
\hline $\begin{array}{l}\text { ( } 3 \text { year) } \\
\text { Legal Variables } \\
\text { English Common Law }\end{array}$ & 0.248 & 1.189 & -0.073 & -0.991 & 6.584 & 564 \\
\hline $\begin{array}{l}\text { Origin } \\
\text { French Civil Law }\end{array}$ & 0.288 & 0.453 & 0.000 & 0.000 & 1.000 & 1108 \\
\hline $\begin{array}{l}\text { Origin } \\
\text { German Civil Law }\end{array}$ & 0.510 & 0.500 & 1.000 & 0.000 & 1.000 & 1108 \\
\hline $\begin{array}{l}\text { Origin } \\
\text { Scandinavian Civil }\end{array}$ & 0.134 & 0.341 & 0.000 & 0.000 & 1.000 & 1108 \\
\hline $\begin{array}{l}\text { Law Origin } \\
\text { Political and } \\
\text { Institutional } \\
\text { Variables }\end{array}$ & 0.068 & 0.251 & 0.000 & 0.000 & 1.000 & 1108 \\
\hline $\begin{array}{l}\text { Herfindahl Index } \\
\text { Fractionalization of }\end{array}$ & 0.448 & 0.267 & 0.383 & 0.016 & 1.000 & 1024 \\
\hline $\begin{array}{l}\text { Government } \\
\text { Political Checks and }\end{array}$ & 0.537 & 0.262 & 0.611 & 0.000 & 0.871 & 1024 \\
\hline Balances & 2.833 & 1.460 & 2.500 & 1.000 & 15.500 & 1116 \\
\hline Left Government & 0.404 & 0.491 & 0.000 & 0.000 & 1.000 & 798 \\
\hline Center Government & 0.084 & 0.278 & 0.000 & 0.000 & 1.000 & 798 \\
\hline $\begin{array}{l}\text { Right Government } \\
\text { Left Dominates }\end{array}$ & 0.512 & 0.500 & 1.000 & 0.000 & 1.000 & 798 \\
\hline $\begin{array}{l}\text { Lawmaking } \\
\text { Center Dominates }\end{array}$ & 0.210 & 0.407 & 0.000 & 0.000 & 1.000 & 772 \\
\hline $\begin{array}{l}\text { Lawmaking } \\
\text { Right Dominates }\end{array}$ & 0.026 & 0.159 & 0.000 & 0.000 & 1.000 & 772 \\
\hline Lawmaking & 0.167 & 0.373 & 0.000 & 0.000 & 1.000 & 772 \\
\hline Index of Corruption & 6.938 & 2.403 & 7.25 & 1.500 & 10.000 & 853 \\
\hline
\end{tabular}


Table 2: Summary Statistics. Continued.

\begin{tabular}{lcccccc}
\hline Variable & Mean & $\begin{array}{c}\text { Standard } \\
\text { Deviation }\end{array}$ & Median & Minimum & Maximum & Observations \\
\hline Protestant & 0.137 & 0.248 & 0.019 & 0.000 & 0.978 & 1325 \\
Catholic & 0.386 & 0.394 & 0.187 & 0.000 & 0.969 & 1345 \\
Muslim & 0.179 & 0.347 & 0.300 & 0.000 & 0.994 & 1345 \\
Other Religions & 0.300 & 0.331 & 0.160 & 0.004 & 1.000 & 1325 \\
\hline
\end{tabular}

Note: All variables are described in detail in the Data Appendix. 
Table 3: Correlations

Year of Enactment/Enforcement and Explanatory Variables

\begin{tabular}{|c|c|c|}
\hline Variable & Year Law Passed & Year Enforced \\
\hline Year Law Enacted & 1.000 & $\begin{array}{c}0.553^{\mathrm{a}} \\
(0.000)\end{array}$ \\
\hline Year Law Enforced & $\begin{array}{c}0.553^{\mathrm{a}} \\
(0.000)\end{array}$ & 1.000 \\
\hline Financial Variables & & \\
\hline Age of Main Stock Exchange & $\begin{array}{c}-.019 \\
(0.521)\end{array}$ & $\begin{array}{c}-0.030 \\
(0.488)\end{array}$ \\
\hline GDP per capita & $\begin{array}{l}-0.159^{\mathrm{a}} \\
(0.000)\end{array}$ & $\begin{array}{l}-0.337^{\mathrm{a}} \\
(0.000)\end{array}$ \\
\hline Market Capitalization/GDP & $\begin{array}{l}-0.264^{\mathrm{a}} \\
(0.000)\end{array}$ & $\begin{array}{c}-0.273^{\mathrm{a}} \\
0.000\end{array}$ \\
\hline Number of Listed Companies & $\begin{array}{l}-0.068^{c} \\
(0.076)\end{array}$ & $\begin{array}{l}-0.118^{b} \\
(0.036)\end{array}$ \\
\hline Foreign Portfolio Investment/Stock Market Capitalization & $\begin{array}{c}0.056 \\
(0.292)\end{array}$ & $\begin{array}{l}-0.125^{d} \\
(0.155)\end{array}$ \\
\hline Stock Market Turnover & $\begin{array}{l}-0.097^{b} \\
(0.029)\end{array}$ & $\begin{array}{l}-0.346^{a} \\
(0.000)\end{array}$ \\
\hline Value Traded Relative to GDP & $\begin{array}{l}-0.193^{\mathrm{a}} \\
(0.000)\end{array}$ & $\begin{array}{l}-0.278^{\mathrm{a}} \\
(0.000)\end{array}$ \\
\hline 1-Year Growth of Market Capitalization & $\begin{array}{c}0.065^{\mathrm{d}} \\
(0.133)\end{array}$ & $\begin{array}{c}0.050 \\
(0.375)\end{array}$ \\
\hline 3-Year Growth of Market Capitalization & $\begin{array}{c}-0.024 \\
(0.583)\end{array}$ & $\begin{array}{l}0.091^{\mathrm{d}} \\
(0.117)\end{array}$ \\
\hline Officially Liberalized ( 1 if yes, 0 if no) & $\begin{array}{l}-0.200^{a} \\
(0.000)\end{array}$ & $\begin{array}{l}-0.105^{b} \\
(0.029)\end{array}$ \\
\hline Legal Variables & & \\
\hline English Common Law Origin & $\begin{array}{l}-0.077^{b} \\
(0.016)\end{array}$ & $\begin{array}{c}0.168^{\mathrm{a}} \\
(0.000)\end{array}$ \\
\hline French Civil Law Origin & $\begin{array}{c}0.146^{a} \\
(0.000)\end{array}$ & $\begin{array}{c}0.272^{a} \\
(0.000)\end{array}$ \\
\hline German Civil Law Origin & $\begin{array}{c}0.010 \\
(0.759)\end{array}$ & $\begin{array}{l}-0.366^{a} \\
(0.000)\end{array}$ \\
\hline Scandinavian Civil Law Origin & $\begin{array}{l}-0.153^{a} \\
(0.000)\end{array}$ & $\begin{array}{l}-0.186^{a} \\
(0.000)\end{array}$ \\
\hline Political and Institutional Variables & & \\
\hline Herfindahl Index & $\begin{array}{c}0.075^{\mathrm{b}} \\
(0.025)\end{array}$ & $\begin{array}{c}0.006 \\
(0.895)\end{array}$ \\
\hline Fractionalization of Government & $\begin{array}{l}-0.082^{b} \\
(0.014)\end{array}$ & $\begin{array}{c}-0.006 \\
(0.906)\end{array}$ \\
\hline Checks and Balances & $\begin{array}{l}-0.121^{\mathrm{a}} \\
(0.000)\end{array}$ & $\begin{array}{l}-0.114^{b} \\
(0.016)\end{array}$ \\
\hline Left Government & $\begin{array}{c}0.111^{\mathrm{a}} \\
(0.003)\end{array}$ & $\begin{array}{c}0.145^{\mathrm{a}} \\
(0.005)\end{array}$ \\
\hline Center Government & $\begin{array}{c}-0.046 \\
(0.211)\end{array}$ & $\begin{array}{c}0.108^{b} \\
(0.038)\end{array}$ \\
\hline Right Government & $\begin{array}{l}-0.084^{b} \\
(0.022)\end{array}$ & $\begin{array}{l}-0.194^{a} \\
(0.000)\end{array}$ \\
\hline
\end{tabular}

Continued 
Table 3: Correlations. Continued.

\begin{tabular}{|l|c|c|}
\multicolumn{1}{|c}{$B . \quad$ Variable } & Year Law Enacted & Year Law Enforced \\
Left Dominates Lawmaking & $0.155^{\mathrm{a}}$ & $0.114^{\mathrm{b}}$ \\
& $(0.000)$ & $(0.032)$ \\
Center Dominates Lawmaking & $-0.128^{\mathrm{a}}$ & 0.044 \\
Right Dominates Lawmaking & $(0.001)$ & $(0.410)$ \\
& -0.041 & $-0.106^{\mathrm{b}}$ \\
Index of Corruption & $(0.272)$ & $(0.047)$ \\
& $-0.158^{\mathrm{a}}$ & $-0.234^{\mathrm{a}}$ \\
Protestant & $(0.000)$ & $(0.000)$ \\
Catholic & $-0.124^{\mathrm{a}}$ & $-0.175^{\mathrm{a}}$ \\
& $(0.000)$ & $(0.000)$ \\
Muslim & $0.213^{\mathrm{a}}$ & $0.269^{\mathrm{a}}$ \\
& $(0.000)$ & $(0.000)$ \\
Other Religions & 0.0027 & $0.396^{\mathrm{a}}$ \\
& $(0.360)$ & $(0.000)$ \\
& $-0.174^{\mathrm{a}}$ & $-0.376^{\mathrm{a}}$ \\
\end{tabular}

Notes: All variables are described in detail in the Data Appendix. The numbers in parentheses are the probability levels ( $\mathrm{p}$-values) at which the null hypothesis of zero correlation can be rejected in two-tailed tests. The Superscripts a, b, c and d denote the $1 \%, 5 \%, 10 \%$ and $15 \%$ statistical significance levels, respectively. 
Table 4: Correlations

Financial and Legal Variables

\begin{tabular}{|c|c|c|c|c|c|c|c|c|c|c|}
\hline Variable & $\begin{array}{l}\text { Age of } \\
\text { Stock } \\
\text { Market }\end{array}$ & $\begin{array}{c}\text { Market Cap./ } \\
\text { GDP }\end{array}$ & Listed Cos. & $\begin{array}{c}\text { Foreign } \\
\text { Portfolio } \\
\text { Inv./Market } \\
\text { Capitaliz'n }\end{array}$ & $\begin{array}{c}\text { Turnover } \\
\text { Ratio }\end{array}$ & $\begin{array}{c}\text { Value } \\
\text { Traded/ } \\
\text { GDP }\end{array}$ & $\begin{array}{l}\text { Common } \\
\text { Law }\end{array}$ & $\begin{array}{c}\text { French Civil } \\
\text { Law }\end{array}$ & $\begin{array}{c}\text { German } \\
\text { Civil } \\
\text { Law }\end{array}$ & $\begin{array}{l}\text { Scand. } \\
\text { Civil } \\
\text { Law }\end{array}$ \\
\hline $\begin{array}{l}\text { Age of Stock } \\
\text { Market }\end{array}$ & 1.000 & & & & & & & & & \\
\hline $\begin{array}{l}\text { Market Cap./ } \\
\text { GDP }\end{array}$ & $\begin{array}{c}0.014 \\
(0.695)\end{array}$ & 1.000 & & & & & & & & \\
\hline Listed Cos. & $\begin{array}{c}0.252^{\mathrm{a}} \\
(0.000)\end{array}$ & $\begin{array}{l}0.235^{\mathrm{a}} \\
(0.000)\end{array}$ & 1.000 & & & & & & & \\
\hline Foreign & 0.070 & 0.069 & $0.221^{\mathrm{a}}$ & 1.000 & & & & & & \\
\hline Portfolio Inv. & $(0.163)$ & $(0.174)$ & $(0.000)$ & & & & & & & \\
\hline Turnover Ratio & $\begin{array}{l}0.086^{\mathrm{b}} \\
(0.014)\end{array}$ & $\begin{array}{c}0.245^{\mathrm{a}} \\
(0.000)\end{array}$ & $\begin{array}{l}0.195^{\mathrm{a}} \\
(0.000)\end{array}$ & $\begin{array}{c}0.373^{\mathrm{a}} \\
(0.000)\end{array}$ & 1.000 & & & & & \\
\hline Value & $0.269^{\mathrm{a}}$ & $0.617^{\mathrm{a}}$ & $0.389^{\mathrm{a}}$ & $0.217^{\mathrm{a}}$ & $0.542^{\mathrm{a}}$ & 1.000 & & & & \\
\hline Traded/GDP & $(0.000)$ & $(0.000)$ & $(0.000)$ & $(0.000)$ & $(0.000)$ & & & & & \\
\hline Common Law & $\begin{array}{l}-0.146^{\mathrm{a}} \\
(0.000)\end{array}$ & $\begin{array}{l}0.093^{\mathrm{b}} \\
(0.015)\end{array}$ & $\begin{array}{l}0.321^{\mathrm{a}} \\
(0.000)\end{array}$ & $\begin{array}{c}0.005 \\
(0.925)\end{array}$ & $\begin{array}{l}-0.084^{b} \\
(0.025)\end{array}$ & $\begin{array}{l}0.122^{\mathrm{a}} \\
(0.001)\end{array}$ & 1.000 & & & \\
\hline $\begin{array}{l}\text { French Civil } \\
\text { Law }\end{array}$ & $\begin{array}{l}-0.027 \\
(0.370)\end{array}$ & $\begin{array}{l}-0.243^{\mathrm{a}} \\
(0.000)\end{array}$ & $\begin{array}{l}-0.322^{\mathrm{a}} \\
(0.000)\end{array}$ & $\begin{array}{l}-0.003 \\
(0.952)\end{array}$ & $\begin{array}{l}-0.226^{a} \\
(0.000)\end{array}$ & $\begin{array}{l}-0.274^{\mathrm{a}} \\
(0.000)\end{array}$ & $\begin{array}{l}-0.649^{\mathrm{a}} \\
(0.000)\end{array}$ & 1.000 & & \\
\hline $\begin{array}{l}\text { German Civil } \\
\text { Law }\end{array}$ & $\begin{array}{c}0.232^{\mathrm{a}} \\
(0.000)\end{array}$ & $\begin{array}{l}0.251^{\mathrm{a}} \\
(0.000)\end{array}$ & $\begin{array}{l}0.101^{\mathrm{a}} \\
(0.000)\end{array}$ & $\begin{array}{l}-0.010 \\
(0.860)\end{array}$ & $\begin{array}{l}0.437^{\mathrm{a}} \\
(0.000)\end{array}$ & $\begin{array}{l}0.215^{\mathrm{a}} \\
(0.000)\end{array}$ & $\begin{array}{l}-0.251^{a} \\
(0.000)\end{array}$ & $\begin{array}{l}-0.402^{\mathrm{a}} \\
(0.000)\end{array}$ & 1.000 & \\
\hline $\begin{array}{l}\text { Scand. Civil } \\
\text { Law }\end{array}$ & $\begin{array}{c}0.002 \\
(0.951)\end{array}$ & $\begin{array}{c}-0.026 \\
(0.497)\end{array}$ & $\begin{array}{l}-0.065^{\mathrm{c}} \\
(0.097)\end{array}$ & $*$ & $\begin{array}{l}-0.016 \\
(0.667)\end{array}$ & $\begin{array}{c}0.047 \\
(0.190)\end{array}$ & $\begin{array}{l}-0.171^{\mathrm{a}} \\
(0.000)\end{array}$ & $\begin{array}{l}-0.275^{\mathrm{a}} \\
(0.000)\end{array}$ & $\begin{array}{l}-0.106^{\mathrm{a}} \\
(0.000)\end{array}$ & 1.000 \\
\hline
\end{tabular}

Notes: All variables are described in detail in the Data Appendix. The numbers in parentheses are the probability levels (p-values) at which the null hypothesis of zero correlation can be rejected in two-tailed tests. The superscripts a, b, c, and denote statistical significance at the $1 \%, 5 \%, 10 \%$ and $15 \%$ levels, respectively. * signifies that no observations are available. 
Table 5: Correlations

Finance, Government, Ideological and Institutional Variables

\begin{tabular}{|c|c|c|c|c|c|c|c|c|c|c|c|c|c|c|c|c|c|c|c|c|}
\hline Variable & (1) & (2) & (3) & (4) & (5) & (6) & (7) & (8) & (9) & (10) & (11) & (12) & (13) & (14) & (15) & (16) & (17) & (18) & (19) & $(20)$ \\
\hline $\begin{array}{l}\text { Age of Main Stock } \\
\text { Exchange } \\
\text { (1) }\end{array}$ & $*$ & & & & & & & & & & & & & & & & & & & \\
\hline $\begin{array}{l}\text { Market Cap./GDP } \\
\text { (2) }\end{array}$ & * & & & & & & & & & & & & & & & & & & & \\
\hline $\begin{array}{l}\text { Listed Cos. } \\
\text { (3) }\end{array}$ & * & * & & & & & & & & & & & & & & & & & & \\
\hline $\begin{array}{l}\text { Foreign Port Inv./ } \\
\text { Mk Cap. (4) }\end{array}$ & * & * & * & & & & & & & & & & & & & & & & & \\
\hline $\begin{array}{l}\text { Turnover Ratio } \\
\text { (5) }\end{array}$ & * & * & * & $*$ & & & & & & & & & & & & & & & & \\
\hline $\begin{array}{l}\text { Value Traded/GDP } \\
\text { (6) }\end{array}$ & * & $*$ & $*$ & * & * & & & & & & & & & & & & & & & \\
\hline $\begin{array}{l}\text { Officially } \\
\text { Liberalized }\end{array}$ & $0.58^{\mathrm{a}}$ & $0.31^{\mathrm{a}}$ & $0.41^{\mathrm{a}}$ & $0.38^{\mathrm{a}}$ & $0.22^{\mathrm{a}}$ & $0.38^{\mathrm{a}}$ & & & & & & & & & & & & & & \\
\hline $\begin{array}{l}\text { (7) } \\
\text { Herfindahl }\end{array}$ & $\begin{array}{l}(0.00) \\
-0.15^{\mathrm{a}}\end{array}$ & $\begin{array}{l}(0.00) \\
-0.17^{a}\end{array}$ & $\begin{array}{l}(0.00) \\
-0.10^{b}\end{array}$ & $\begin{array}{l}(0.00) \\
-0.01\end{array}$ & $\begin{array}{c}(0.00) \\
0.02\end{array}$ & $\begin{array}{l}(0.00) \\
-0.15^{\mathrm{a}}\end{array}$ & $-0.32^{\mathrm{a}}$ & & & & & & & & & & & & & \\
\hline & $(0.00)$ & $(0.00)$ & $(0.02)$ & $(0.84)$ & $(0.59)$ & $(0.00)$ & $(0.00)$ & & & & & & & & & & & & & \\
\hline Gov't Frac & $0.20^{2}$ & $0.13^{\mathrm{a}}$ & $0.10^{4}$ & 0.04 & 0.00 & $0.16^{a}$ & $0.38^{a}$ & $-0.93^{\mathrm{a}}$ & & & & & & & & & & & & \\
\hline (9) & $(0.00)$ & $(0.00)$ & $(0.01)$ & $(0.44)$ & $(0.99)$ & $(0.00)$ & $(0.00)$ & $(0.00)$ & & & & & & & & & & & & \\
\hline $\begin{array}{l}\text { Checks \& Bal } \\
\text { (10) }\end{array}$ & $\begin{array}{l}0.11^{\mathrm{a}} \\
(0.00)\end{array}$ & $\begin{array}{l}0.12^{\mathrm{a}} \\
(0.00)\end{array}$ & $\begin{array}{c}0.05 \\
(0.18)\end{array}$ & $\begin{array}{l}0.14^{\mathrm{a}} \\
(0.01)\end{array}$ & $\begin{array}{l}0.09^{6} \\
(0.02)\end{array}$ & $\begin{array}{l}0.11^{\mathrm{a}} \\
(0.00)\end{array}$ & $\begin{array}{l}0.31^{\mathrm{a}} \\
(0.00)\end{array}$ & $\begin{array}{l}-0.44^{\mathrm{a}} \\
(0.00)\end{array}$ & $\begin{array}{l}0.50^{\mathrm{a}} \\
(0.00)\end{array}$ & & & & & & & & & & & \\
\hline Corruption & $0.49^{2}$ & $0.35^{a}$ & $0.11^{a}$ & $-0.16^{a}$ & $0.12^{\mathrm{a}}$ & $0.28^{a}$ & $0.38^{a}$ & $-0.43^{\mathrm{a}}$ & $0.42^{a}$ & $0.23^{\mathrm{a}}$ & & & & & & & & & & \\
\hline (11) & $(0.00)$ & $(0.00)$ & $(0.01)$ & $(0.01)$ & $(0.00)$ & $(0.00)$ & $(0.00)$ & $(0.00)$ & $(0.00)$ & $(0.00)$ & & & & & & & & & & \\
\hline $\begin{array}{l}\text { Left Gov't } \\
\text { (12) }\end{array}$ & $\begin{array}{c}0.02 \\
(0.66)\end{array}$ & $\begin{array}{l}-0.12^{a} \\
(0.01)\end{array}$ & $\begin{array}{c}0.04 \\
(0.44)\end{array}$ & $\begin{array}{l}0.10^{\mathrm{d}} \\
(0.12)\end{array}$ & $\begin{array}{l}-0.04 \\
(0.34)\end{array}$ & $\begin{array}{l}-0.03 \\
(0.44)\end{array}$ & $\begin{array}{l}-0.02 \\
(0.59)\end{array}$ & $\begin{array}{l}0.29^{a} \\
(0.00)\end{array}$ & $\begin{array}{l}-0.30^{\mathrm{a}} \\
(0.00)\end{array}$ & $\begin{array}{l}-0.06^{6} \\
(0.07)\end{array}$ & $\begin{array}{l}-0.02 \\
(0.58)\end{array}$ & & & & & & & & & \\
\hline Right Gov't & 0.03 & $0.10^{b}$ & 0.02 & $-0.11^{\mathrm{c}}$ & $0.11^{\mathrm{a}}$ & $0.09^{6}$ & 0.02 & $-0.23^{\mathrm{a}}$ & $0.24^{a}$ & 0.00 & 0.05 & $-0.84^{\mathrm{a}}$ & & & & & & & & \\
\hline (13) & $(0.44)$ & $(0.02)$ & $(0.60)$ & $(0.09)$ & $(0.01)$ & $(0.03)$ & $(0.62)$ & $(0.00)$ & $(0.00)$ & $(0.93)$ & $(0.24)$ & $(0.00)$ & & & & & & & & \\
\hline $\begin{array}{l}\text { Center Gov't } \\
\text { (14) }\end{array}$ & $\begin{array}{l}-0.08^{6} \\
(0.03)\end{array}$ & $\begin{array}{c}0.03 \\
(0.46)\end{array}$ & $\begin{array}{l}-0.11^{\mathrm{b}} \\
(0.02)\end{array}$ & $\begin{array}{c}0.02 \\
(0.72)\end{array}$ & $\begin{array}{l}-0.12^{\mathrm{a}} \\
(0.00)\end{array}$ & $\begin{array}{l}-0.10^{b} \\
(0.02)\end{array}$ & $\begin{array}{l}0.00 \\
(0.93)\end{array}$ & $\begin{array}{l}-0.10^{\mathrm{a}} \\
(0.01)\end{array}$ & $\begin{array}{l}0.09^{a} \\
(0.01)\end{array}$ & $\begin{array}{l}0.11^{a} \\
(0.00)\end{array}$ & $\begin{array}{l}-0.06 \\
(0.18)\end{array}$ & $\begin{array}{l}-0.25^{\mathrm{a}} \\
(0.00)\end{array}$ & $\begin{array}{l}0.08^{\mathrm{b}} \\
(0.03)\end{array}$ & & & & & & & \\
\hline Left Dom. & $-0.14^{a}$ & $-0.15^{a}$ & $-0.09^{c}$ & 0.04 & -0.04 & $-0.14^{a}$ & $-0.27^{\mathrm{a}}$ & $0.58^{4}$ & $-0.58^{a}$ & $-0.20^{a}$ & $-0.18^{a}$ & $0.61^{a}$ & $-0.51^{a}$ & $-0.16^{\mathrm{a}}$ & & & & & & \\
\hline (15) & $(0.00)$ & $(0.00)$ & $(0.07)$ & $(0.50)$ & $(0.41)$ & $(0.00)$ & $(0.00)$ & $(0.00)$ & $(0.00)$ & $(0.00)$ & $(0.00)$ & $(0.00)$ & $(0.00)$ & $(0.00)$ & & & & & & \\
\hline $\begin{array}{l}\text { Center Dom. } \\
\text { (16) }\end{array}$ & $\begin{array}{l}-0.07^{\mathrm{c}} \\
(0.06)\end{array}$ & $\begin{array}{l}0.04 \\
(0.30)\end{array}$ & $\begin{array}{l}-0.05 \\
(0.32)\end{array}$ & $\begin{array}{l}-0.04 \\
(0.58)\end{array}$ & $\begin{array}{l}-0.05 \\
(0.28)\end{array}$ & $\begin{array}{r}0.00 \\
(0.96)\end{array}$ & $\begin{array}{l}-0.07^{\mathrm{c}} \\
(0.08)\end{array}$ & $\begin{array}{l}0.09^{a} \\
(0.01)\end{array}$ & $\begin{array}{l}-0.09^{6} \\
(0.02)\end{array}$ & $\begin{array}{l}-0.06^{6} \\
(0.09)\end{array}$ & $\begin{array}{l}-0.11^{\mathrm{a}} \\
(0.01)\end{array}$ & $\begin{array}{l}-0.14^{\mathrm{a}} \\
(0.00)\end{array}$ & $\begin{array}{l}-0.16^{\mathrm{a}} \\
(0.00)\end{array}$ & $\begin{array}{l}0.53^{\mathrm{a}} \\
(0.00)\end{array}$ & $\begin{array}{l}-0.08^{\mathrm{b}} \\
(0.02)\end{array}$ & & & & & \\
\hline Right Dom. & $-0.19^{a}$ & 0.03 & -0.04 & -0.07 & $0.14^{a}$ & $-0.13^{\mathrm{a}}$ & $-0.26^{a}$ & $0.22^{4}$ & $-0.22^{a}$ & $-0.24^{\mathrm{a}}$ & $-0.20^{a}$ & $-0.38^{a}$ & $0.45^{2}$ & $-0.14^{a}$ & $-0.23^{\mathrm{a}}$ & $-0.07^{\mathrm{b}}$ & & & & \\
\hline (17) & $(0.00)$ & $(0.55)$ & $(0.46)$ & $(0.34)$ & $(0.00)$ & $(0.00)$ & $(0.00)$ & $(0.00)$ & $(0.00)$ & $(0.00)$ & $(0.00)$ & $(0.00)$ & $(0.00)$ & $(0.00)$ & $(0.00)$ & $(0.04)$ & & & & \\
\hline $\begin{array}{l}\text { Protestant } \\
\text { (18) }\end{array}$ & $\begin{array}{l}0.14^{a} \\
(000)\end{array}$ & $\begin{array}{l}0.12^{2} \\
(0.00)\end{array}$ & $\begin{array}{l}-0.02 \\
(0.54)\end{array}$ & $\begin{array}{l}-0.10^{6} \\
(0.05)\end{array}$ & $\begin{array}{l}0.01 \\
(0.87)\end{array}$ & $\begin{array}{l}0.13^{\mathrm{a}} \\
(0.00)\end{array}$ & $\begin{array}{l}0.21^{\mathrm{a}} \\
(0.00)\end{array}$ & $\begin{array}{l}-0.13^{\mathrm{a}} \\
(0.00)\end{array}$ & $\begin{array}{l}0.17^{\mathrm{a}} \\
(000)\end{array}$ & $\begin{array}{l}0.20^{2} \\
(0.00)\end{array}$ & $\begin{array}{l}0.42^{2} \\
(0.00)\end{array}$ & $\begin{array}{c}0.01 \\
(075)\end{array}$ & $\begin{array}{l}0.01 \\
0.67)\end{array}$ & $\begin{array}{l}-0.05 \\
(0.19)\end{array}$ & $\begin{array}{l}-0.10^{a} \\
(0.01)\end{array}$ & $\begin{array}{l}-0.01 \\
(073)\end{array}$ & $\begin{array}{l}-0.02 \\
(0.51)\end{array}$ & & & \\
\hline Catholic & $0.22^{2}$ & $-0.12^{a}$ & $-0.14^{a}$ & -0.06 & $-0.11^{a}$ & $-0.17^{a}$ & $0.10^{a}$ & $-0.20^{a}$ & $0.26^{2}$ & 0.02 & $0.18^{\mathrm{a}}$ & $-0.08^{b}$ & -0.01 & $0.15^{\mathrm{a}}$ & $-0.18^{a}$ & 0.03 & $-0.10^{a}$ & $-0.28^{a}$ & & \\
\hline (19) & $(0.00)$ & $(0.00)$ & $(0.00)$ & $(0.27)$ & $(0.00)$ & $(0.00)$ & $(0.00)$ & $(0.00)$ & $(0.00)$ & $(0.47)$ & $(0.00)$ & $(0.03)$ & $(0.87)$ & $(0.00)$ & $(0.00)$ & $(0.37)$ & $(0.00)$ & $(0.00)$ & & \\
\hline Muslim & $-0.26^{2}$ & $-0.11^{a}$ & $0.06^{\circ}$ & -0.04 & $-0.11^{a}$ & $-0.10^{\mathrm{a}}$ & $-0.23^{a}$ & $0.14^{2}$ & $-0.26^{a}$ & $-0.25^{a}$ & $-0.44^{a}$ & 0.03 & 0.02 & $-0.08^{6}$ & $0.11^{a}$ & -0.05 & $0.07^{c}$ & $-0.27^{a}$ & $-0.47^{\mathrm{a}}$ & \\
\hline $\begin{array}{l}\text { (20) } \\
\text { Other Religion }\end{array}$ & $\begin{array}{l}(0.00) \\
-0.10^{\mathrm{a}}\end{array}$ & $\begin{array}{l}(0.00) \\
0.16^{\mathrm{a}}\end{array}$ & $\begin{array}{l}(0.09) \\
0.12^{2}\end{array}$ & $\begin{array}{l}(0.45) \\
0.16^{a}\end{array}$ & $\begin{array}{l}(0.00) \\
0.23^{\mathrm{a}}\end{array}$ & $\begin{array}{l}(0.00) \\
0.21^{a}\end{array}$ & $\begin{array}{c}(0.00) \\
-0.03\end{array}$ & $\begin{array}{l}(0.00) \\
0.21^{a}\end{array}$ & $\begin{array}{l}(0.00) \\
-0.18^{a}\end{array}$ & $\begin{array}{l}(0.00) \\
0.09^{a}\end{array}$ & $\begin{array}{l}(0.00) \\
-0.06\end{array}$ & $\begin{array}{l}(0.39) \\
0.07^{\circ}\end{array}$ & $\begin{array}{r}(0.64) \\
-0.02\end{array}$ & $\begin{array}{l}(0.02) \\
-0.08^{b}\end{array}$ & $\begin{array}{l}(0.00) \\
0.23^{\mathrm{a}}\end{array}$ & $\begin{array}{c}(0.19) \\
0.01\end{array}$ & $\begin{array}{l}(0.06) \\
0.14^{a}\end{array}$ & $\begin{array}{l}(0.00) \\
-0.13^{\mathrm{a}}\end{array}$ & $\begin{array}{l}(0.00) \\
-0.49^{a}\end{array}$ & $-0.30^{\mathrm{a}}$ \\
\hline (21) & $(0.00)$ & $(0.00)$ & $(0.00)$ & $(0.00)$ & $(0.00)$ & $(0.00)$ & $(0.32)$ & $(0.00)$ & $(0.00)$ & $(0.00)$ & $(0.07)$ & $(0.06)$ & $(0.54)$ & $(0.02)$ & $(0.00)$ & $(0.89)$ & $(0.00)$ & $(0.00)$ & $(0.00)$ & $(0.00)$ \\
\hline
\end{tabular}

Continued 
Table 5: Correlations. Continued.

Notes: Column 1 is the age of the country's main stock exchange; column 2 is annual stock market capitalization relative to GDP; column 3 is the annual number of listed companies; column 4 is annual foreign portfolio investment relative to stock market capitalization; column 5 is the annual stock market turnover ratio; column 6 is the annual value traded relative to GDP; column 7 is a dummy variable indicating whether the stock market has officially liberalized; column 8 is the annual Herfindahl index of government concentration; column 9 is the annual measure of the fractionalization of the legislature; column 10 is the annual measure of average checks and balances; column 11 is the average level corruption level over the years 1980-1983; column 12 is a dummy variable that equals one if the largest government party is Left and zero otherwise; column 13 is a dummy variable that equals one if the largest government party is Right and zero otherwise; column 14 is a dummy variable that equals one if the largest government party is Center and zero otherwise; column 15 is a dummy variable that equals one if the majority party in the legislature is Left and zero otherwise; column 16 is a dummy variable that equals one if the majority party in the legislature is Center and zero otherwise; column 17 is a dummy variable that equals one if the majority party in the legislature is Right and zero otherwise; column 18 is the percentage of the population that is Protestant; column 19 is the percentage of the population that is Catholic; column 20 is the percentage of the population that is Muslim. All variables are described in detail in the Data Appendix. The numbers in parentheses are the probability levels ( $\mathrm{p}$-values) at which the null hypothesis of zero correlation can be rejected in two-tailed tests. The superscripts a, b, c, and d denote statistical significance at the 1\%,5\%,10\% and $15 \%$ levels, respectively. * signifies that values are reported in Table 3. 
Table 6

Weibull Hazard Model of Financial Determinants of the Enactment and Enforcement of Insider Trading Laws, 1980-1997

Panel A: Enactment of Insider Trading Laws

\begin{tabular}{|c|c|c|c|c|c|c|c|c|c|c|}
\hline Variable & $(1)$ & $(2)$ & (3) & $(4)$ & $(5)$ & $(6)$ & $(7)$ & $(8)$ & $(9)$ & $(10)$ \\
\hline 1-Year Growth of Market & $0.836^{\mathrm{a}}$ & $1.101^{\mathrm{b}}$ & $2.260^{\mathrm{c}}$ & $0.720^{\mathrm{a}}$ & $0.720^{b}$ & $0.897^{\mathrm{b}}$ & $1.607^{\mathrm{b}}$ & $2.868^{\mathrm{b}}$ & $0.769^{\mathrm{a}}$ & $0.755^{\mathrm{a}}$ \\
\hline Capitalization/GDP & $(0.339)$ & $(0.484)$ & $(.1545)$ & $(0.265)$ & $(0.302)$ & $(0.391)$ & $(0.679)$ & $(1.326)$ & $(0.294)$ & $(0.303)$ \\
\hline 3-Year Growth of Market & $0.643^{\mathrm{a}}$ & $0.699^{\mathrm{a}}$ & $0.635^{\mathrm{c}}$ & $0.533^{\mathrm{a}}$ & $0.716^{\mathrm{a}}$ & $0.890^{\mathrm{a}}$ & $0.950^{\mathrm{b}}$ & $0.774^{c}$ & $0.600^{\mathrm{a}}$ & $0.815^{\mathrm{a}}$ \\
\hline Capitalization/GDP & $(0.193)$ & $(0.252)$ & $(0.398)$ & $(0.187)$ & $(0.206)$ & $(0.254)$ & $(0.392)$ & $(0.439)$ & $(0.207)$ & $(0.249)$ \\
\hline Market Capitalization/GDP & $\begin{array}{l}-0.590^{c} \\
(0.359)\end{array}$ & & & & & $\begin{array}{l}-1.215^{b} \\
(0.494)\end{array}$ & & & & \\
\hline No. Listed Companies & & $\begin{array}{l}-0.000 \\
(0.001)\end{array}$ & & & & & $\begin{array}{c}0.001 \\
(0.001)\end{array}$ & & & \\
\hline $\begin{array}{l}\text { Foreign Portfolio Investments/Market } \\
\text { Capitalization }\end{array}$ & & & $\begin{array}{c}-13.789^{\mathrm{a}} \\
(3.066)\end{array}$ & & & & & $\begin{array}{l}16.106^{\mathrm{d}} \\
(11.322)\end{array}$ & & \\
\hline Turnover Ratio & & & & $\begin{array}{l}-0.281^{\mathrm{a}} \\
(0.072)\end{array}$ & & & & & $\begin{array}{l}-0.230^{\mathrm{a}} \\
(0.111)\end{array}$ & \\
\hline Value Traded/GDP & & & & & $\begin{array}{l}-0.631 \\
(0.965)\end{array}$ & & & & & $\begin{array}{c}1.704 \\
(1.565)\end{array}$ \\
\hline Official Liberalization & & & & & & $\begin{array}{l}-0.367 \\
(0.266)\end{array}$ & $\begin{array}{l}-1.166^{\mathrm{c}} \\
(0.670)\end{array}$ & $\begin{array}{l}-1.622^{\mathrm{b}} \\
(0.750)\end{array}$ & $\begin{array}{c}-0.371^{\mathrm{c}} \\
0.224\end{array}$ & $\begin{array}{l}-0.562^{b} \\
(0.256)\end{array}$ \\
\hline Constant & $\begin{array}{l}2.978^{\mathrm{a}} \\
(0.195)\end{array}$ & $\begin{array}{l}2.844^{\mathrm{a}} \\
(0.292)\end{array}$ & $\begin{array}{l}3.854^{\mathrm{a}} \\
(0.832)\end{array}$ & $\begin{array}{l}2.867^{\mathrm{a}} \\
(0.162)\end{array}$ & $\begin{array}{l}2.928^{\mathrm{a}} \\
(0.187)\end{array}$ & $\begin{array}{r}3.407^{\mathrm{a}} \\
(0.351)\end{array}$ & $\begin{array}{l}3.390^{\mathrm{a}} \\
(0.571)\end{array}$ & $\begin{array}{l}4.684^{\mathrm{a}} \\
(0.953)\end{array}$ & $\begin{array}{l}3.083^{\mathrm{a}} \\
(0.223)\end{array}$ & $\begin{array}{r}3.213^{\mathrm{a}} \\
(0.272)\end{array}$ \\
\hline No. Observations & 248 & 145 & 115 & 248 & 240 & 237 & 136 & 113 & 234 & 226 \\
\hline Log Likelihood & -7.994 & -5.40 & -5.07 & -7.90 & -8.034 & -2.607 & -0.692 & -2.672 & -4.865 & -3.198 \\
\hline $\mathrm{P}-$ Value of $\mathrm{Chi}^{2}$ & $0.002^{\mathrm{a}}$ & $0.002^{\mathrm{a}}$ & $0.000^{\mathrm{a}}$ & $0.000^{\mathrm{a}}$ & $0.003^{\mathrm{a}}$ & $0.008^{\mathrm{a}}$ & $0.042^{\mathrm{a}}$ & $0.002^{\mathrm{a}}$ & $0.004^{\mathrm{a}}$ & $0.009^{\mathrm{a}}$ \\
\hline
\end{tabular}

Notes: The regression is a Weibull hazard model, where the dependent variable is the log expected time until enactment of insider trading legislation, that is, $\ln (T)=x^{\prime} b+e$. Each independent variable is measured for each country in each year. The independent variables are the 1 -year growth rate of stock market capitalization relative to GDP; the 3-year growth rate of stock market capitalization relative to GDP; stock market capitalization relative to GDP; the number of listed companies; foreign portfolio investment relative to stock market capitalization; stock market turnover; total value traded relative to GDP; and an indicator that equals one if the stock market has been officially liberalized, and zero otherwise. All variables are described in detail in the Data Appendix. Robust standard errors are reported in parentheses. The superscripts a, b, c and d denote the $1 \%, 5 \%, 10 \%$, and $15 \%$ significance levels, respectively. 
Table 6: Weibull Hazard Model of Financial Determinants. Continued.

\section{Panel B: Enforcement of Insider Trading Laws}

\begin{tabular}{|c|c|c|c|c|c|c|c|c|c|c|}
\hline Variable & (1) & (2) & (3) & (4) & (5) & (6) & (7) & (8) & (9) & $(10)$ \\
\hline 1-Year Growth of Market & $0.472^{\mathrm{b}}$ & $0.509^{\mathrm{a}}$ & $0.213^{\mathrm{a}}$ & $0.335^{\mathrm{b}}$ & $0.507^{\mathrm{a}}$ & $0.486^{\mathrm{d}}$ & $0.581^{\mathrm{a}}$ & $0.371^{\mathrm{a}}$ & $0.310^{\mathrm{b}}$ & $0.397^{\mathrm{d}}$ \\
\hline Capitalization/GDP & $(0.208)$ & $(0.151)$ & $(0.057)$ & $(0.153)$ & $(0.197)$ & $(0.308)$ & $(0.181)$ & $(0.141)$ & $(0.150)$ & $(0.270)$ \\
\hline 3-Year Growth of Market & $0.508^{\mathrm{d}}$ & $0.397^{\mathrm{c}}$ & 0.204 & $0.319^{\mathrm{b}}$ & 0.386 & $0.355^{\mathrm{c}}$ & $0.311^{\mathrm{c}}$ & 0.432 & $0.306^{\mathrm{b}}$ & 0.185 \\
\hline Capitalization/GDP & $(0.328)$ & $(0.209)$ & $(0.176)$ & $(0.162)$ & $(0.322)$ & $(0.216)$ & $(0.166)$ & $(0.308)$ & $(0.157)$ & $(0.214)$ \\
\hline Market Capitalization/GDP & $\begin{array}{l}-0.900^{\mathrm{d}} \\
(0.622)\end{array}$ & & & & & $\begin{array}{l}-0.987^{c} \\
(0.602)\end{array}$ & & & & \\
\hline No. Listed Companies & & $\begin{array}{l}-0.001^{\mathrm{a}} \\
(0.000)\end{array}$ & & & & & $\begin{array}{l}-0.001^{\mathrm{a}} \\
(0.000)\end{array}$ & & & \\
\hline Foreign Portfolio Investment/Market & & & $-9.135^{\mathrm{a}}$ & & & & & $-13.617^{\mathrm{a}}$ & & \\
\hline Capitalization & & & $(1.746)$ & & & & & $(3.837)$ & & \\
\hline Turnover Ratio & & & & $\begin{array}{l}-1.478^{\mathrm{a}} \\
(0.422)\end{array}$ & & & & & $\begin{array}{l}-1.547^{\mathrm{a}} \\
(0.410)\end{array}$ & \\
\hline Value Traded/GDP & & & & & $\begin{array}{l}-3.387^{\mathrm{c}} \\
(1.953)\end{array}$ & & & & & $\begin{array}{l}-4.783^{b} \\
(2.188)\end{array}$ \\
\hline Official Liberalization & & & & & & $\begin{array}{l}-0.050 \\
(0.407)\end{array}$ & $\begin{array}{c}-0.146 \\
(0.368)\end{array}$ & $\begin{array}{l}-0.187 \\
(0.629)\end{array}$ & $\begin{array}{c}0.160 \\
(0.414)\end{array}$ & $\begin{array}{c}0.835 \\
(0.745)\end{array}$ \\
\hline Constant & $\begin{array}{c}2.450^{\mathrm{a}} \\
(0.335)\end{array}$ & $\begin{array}{l}2.441^{\mathrm{a}} \\
(0.213)\end{array}$ & $\begin{array}{l}2.758^{\mathrm{a}} \\
(0.255)\end{array}$ & $\begin{array}{l}2.791^{\mathrm{a}} \\
(0.264)\end{array}$ & $\begin{array}{c}2.800 \\
(0.555)\end{array}$ & $\begin{array}{l}2.558^{\mathrm{a}} \\
(0.415)\end{array}$ & $\begin{array}{l}2.574^{\mathrm{a}} \\
(0.348)\end{array}$ & $\begin{array}{l}3.128^{\mathrm{a}} \\
(0.582)\end{array}$ & $\begin{array}{l}2.721^{\mathrm{a}} \\
(0.313)\end{array}$ & $\begin{array}{l}2.664^{\mathrm{a}} \\
(0.484)\end{array}$ \\
\hline No. Observations & 137 & 141 & 86 & 141 & 143 & 131 & 130 & 81 & 133 & 133 \\
\hline Log Likelihood & -7.868 & -9.464 & -0.904 & -6.854 & -10.503 & -5.525 & -6.565 & -0.722 & -6.713 & -7.04 \\
\hline $\mathrm{P}-$ Value of $\mathrm{Chi}^{2}$ & $0.135^{\mathrm{d}}$ & $0.001^{\mathrm{a}}$ & $0.000^{\mathrm{a}}$ & $0.003^{\mathrm{a}}$ & $0.023^{\mathrm{a}}$ & 0.378 & $0.000^{\mathrm{a}}$ & $0.000^{\mathrm{a}}$ & $0.002^{\mathrm{a}}$ & $0.00^{\mathrm{a}}$ \\
\hline
\end{tabular}

Notes: The regression is a Weibull hazard model, where the dependent variable is the log expected time until enforcement of insider trading legislation, that is, $\ln (T)=x^{\prime} b+e$. Each independent variable is measured for each country in each year. The independent variables are the 1 -year growth rate of stock market capitalization relative to GDP; the 3 -year growth rate of stock market capitalization relative to GDP; stock market capitalization relative to GDP; the number of listed companies; foreign portfolio investment relative to stock market capitalization; stock market turnover; total value traded relative to GDP; and an indicator that equals one if the stock market has been officially liberalized, and zero otherwise. All variables are described in detail in the Data Appendix. Robust standard errors are reported in parentheses. The superscripts a, b, c and d denote the 1\%, 5\%, 10\%, and 15\% significance levels, respectively. 
Table 7

Weibull Hazard Model of Financial and Legal Determinants of the Enactment and Enforcement of Insider Trading Laws, 1980-1997

\section{Panel A: Enactment of Insider Trading Laws}

\begin{tabular}{|c|c|c|c|c|c|c|c|c|c|c|c|}
\hline Variable & (1) & (2) & (3) & (4) & $(5)$ & (6) & (7) & $(8)$ & (9) & (10) & $(11)$ \\
\hline 1-Year Growth of Market & & $0.855^{\mathrm{a}}$ & $1.375^{\mathrm{a}}$ & 2.761 & $0.725^{\mathrm{a}}$ & $0.614^{\mathrm{a}}$ & $0.980^{\mathrm{a}}$ & $2.274^{\mathrm{a}}$ & $4.150^{\mathrm{a}}$ & $0.868^{\mathrm{a}}$ & $0.747^{b}$ \\
\hline Capitalization/GDP & & $(0.287)$ & $(0.530)$ & $(2.035)$ & $(0.243)$ & $(0.240)$ & $(0.359)$ & $(0.906)$ & $(1.237)$ & $(0.294)$ & $(0.324)$ \\
\hline 3-Year Growth of Market & & $0.546^{\mathrm{a}}$ & $0.648^{\mathrm{b}}$ & 0.388 & $0.456^{\mathrm{b}}$ & $0.690^{\mathrm{a}}$ & $0.786^{\mathrm{a}}$ & $0.556^{\mathrm{c}}$ & $0.587^{\mathrm{c}}$ & $0.500^{\mathrm{b}}$ & $0.842^{\mathrm{a}}$ \\
\hline Capitalization/GDP & & $(0.203)$ & $(0.271)$ & $(0.307)$ & $(0.212)$ & $(0.212)$ & $(0.256)$ & $(0.301)$ & $(0.354)$ & $(0.231)$ & $(0.291)$ \\
\hline Market Capitalization/GDP & & $\begin{array}{l}-0.405 \\
(0.307)\end{array}$ & & & & & $\begin{array}{l}-1.078^{a} \\
(0.416)\end{array}$ & & & & \\
\hline No. Listed Companies & & & $\begin{array}{l}-0.000 \\
(0.001)\end{array}$ & & & & & $\begin{array}{c}0.001 \\
(0.001)\end{array}$ & & & \\
\hline Foreign Portfolio Investments/Market & & & & -44.267 & & & & & $-66.803^{c}$ & & \\
\hline Capitalization & & & & $(37.658)$ & & & & & $(37.006)$ & & \\
\hline Turnover Ratio & & & & & $\begin{array}{l}-0.176^{\mathrm{c}} \\
(0.091)\end{array}$ & & & & & $\begin{array}{l}-0.202^{c} \\
(0.119)\end{array}$ & \\
\hline Value Traded/GDP & & & & & & $\begin{array}{l}-0.050 \\
(0.790)\end{array}$ & & & & & $\begin{array}{c}2.063 \\
(1.647)\end{array}$ \\
\hline Official Liberalization & & & & & & & $\begin{array}{c}-0.321 \\
(0.295)\end{array}$ & $\begin{array}{l}-1.292^{\mathrm{d}} \\
(0.799)\end{array}$ & $\begin{array}{l}-2.169^{\mathrm{a}} \\
(0.700)\end{array}$ & $\begin{array}{l}-0.379^{\mathrm{d}} \\
(0.237)\end{array}$ & $\begin{array}{l}-0.643^{b} \\
(0.320)\end{array}$ \\
\hline French Civil Law & $\begin{array}{c}0.341^{\mathrm{a}} \\
(0.136)\end{array}$ & $\begin{array}{c}0.222 \\
(0.241)\end{array}$ & $\begin{array}{c}0.110 \\
(0.398)\end{array}$ & $\begin{array}{c}0.032 \\
(0.774)\end{array}$ & $\begin{array}{c}0.193 \\
(0.221)\end{array}$ & $\begin{array}{c}0.212 \\
(0.237)\end{array}$ & $\begin{array}{c}0.335^{\mathrm{d}} \\
0.214\end{array}$ & $\begin{array}{c}0.417 \\
(0.391)\end{array}$ & $\begin{array}{c}0.015 \\
(0.552)\end{array}$ & $\begin{array}{c}0.241 \\
(0.206)\end{array}$ & $\begin{array}{c}0.285 \\
(0.217)\end{array}$ \\
\hline Scand. Civil Law & $\begin{array}{l}-0.210 \\
(0.192)\end{array}$ & $\begin{array}{l}-0.388^{d} \\
(0.256)\end{array}$ & $\begin{array}{l}-0.941^{\mathrm{d}} \\
(0.625)\end{array}$ & * & $\begin{array}{l}-0.356^{\mathrm{d}} \\
(0.245)\end{array}$ & $\begin{array}{l}-0.439^{\mathrm{d}} \\
(0.276)\end{array}$ & $\begin{array}{l}-0.184 \\
(0.211)\end{array}$ & $\begin{array}{l}-0.057 \\
(0.543)\end{array}$ & * & $\begin{array}{l}-0.136 \\
(0.234)\end{array}$ & $\begin{array}{l}-0.133 \\
(0.282)\end{array}$ \\
\hline Constant & $\begin{array}{l}2.287^{\mathrm{a}} \\
(0.105)\end{array}$ & $\begin{array}{l}2.883^{\mathrm{a}} \\
(0.287)\end{array}$ & $\begin{array}{c}3.152^{\mathrm{a}} \\
(0.591)\end{array}$ & $\begin{array}{l}4.123^{\mathrm{a}} \\
(1.576)\end{array}$ & $\begin{array}{c}2.756^{\mathrm{a}} \\
(0.214)\end{array}$ & $\begin{array}{c}2.777^{a} \\
(0.261)\end{array}$ & $\begin{array}{c}3.199^{\mathrm{a}} \\
(0.388)\end{array}$ & $\begin{array}{c}3.452^{\mathrm{a}} \\
(0.782)\end{array}$ & $\begin{array}{l}5.815^{\mathrm{a}} \\
(1.047)\end{array}$ & $\begin{array}{l}2.959^{\mathrm{a}} \\
(0.270)\end{array}$ & $\begin{array}{l}3.070^{\mathrm{a}} \\
(0.335)\end{array}$ \\
\hline No. Observations & 600 & 236 & 133 & 104 & 236 & 228 & 226 & 125 & 103 & 223 & 215 \\
\hline Log Likelihood & -48.533 & -4.599 & -2.198 & -4.725 & -5.685 & -5.046 & -1.192 & 1.619 & -1.520 & -3.504 & -1.696 \\
\hline $\mathrm{P}-$ Value of $\mathrm{Chi}^{2}$ & $0.012^{\mathrm{a}}$ & $0.002^{\mathrm{a}}$ & $0.006^{\mathrm{a}}$ & $0.061^{\mathrm{c}}$ & $0.000^{\mathrm{a}}$ & $0.003^{\mathrm{a}}$ & $0.000^{\mathrm{a}}$ & $0.000^{\mathrm{a}}$ & $0.000^{\mathrm{a}}$ & $0.000^{\mathrm{a}}$ & $0.000^{\mathrm{a}}$ \\
\hline
\end{tabular}

Notes: The regression is a Weibull hazard model, where the dependent variable is the log expected time until enactment of insider trading legislation, that is, $\ln (T)=x^{\prime} b+e$. Each independent variable is measured for each country in each year. The independent variables are the 1 -year growth rate of stock market 
Notes to Panel A. Continued

capitalization relative to GDP; the 3 -year growth rate of stock market capitalization relative to GDP; stock market capitalization relative to GDP; the number of listed companies; foreign portfolio investment relative to stock market capitalization; stock market turnover; total value traded relative to GDP; an indicator that equals one if the stock market has been officially liberalized, and zero otherwise; an indicator that equals one for French civil law, and zero otherwise; an indicator that equals one for German civil law, and zero otherwise; and an indicator that equals one for Scandinavian civil law (English common law is the omitted category). All variables are described in detail in the Data Appendix. Robust standard errors are reported in parentheses. The superscripts $\mathrm{a}, \mathrm{b}, \mathrm{c}$ and denote the $1 \%, 5 \%, 10 \%$, and $15 \%$ significance levels, respectively. $*$ signifies variable is dropped due to collinearity. 
Table 7: Weibull Hazard Model of Financial and Legal Determinants. Continued

\section{Panel B: Enforcement of Insider Trading Laws}

\begin{tabular}{|c|c|c|c|c|c|c|}
\hline C. Variable & (1) & (2) & (3) & (4) & $(5)$ & (6) \\
\hline 1-Year Growth of Market & & $0.371^{\mathrm{c}}$ & $0.369^{\mathrm{a}}$ & $0.103^{\mathrm{a}}$ & $0.249^{\mathrm{a}}$ & $0.401^{\mathrm{a}}$ \\
\hline Capitalization/GDP & & $(0.195)$ & $(0.092)$ & $(0.040)$ & $(0.088)$ & $(0.130)$ \\
\hline 3-Year Growth of Market & & $0.525^{\mathrm{d}}$ & $0.476^{\mathrm{b}}$ & $0.191^{\mathrm{a}}$ & $0.250^{\mathrm{c}}$ & 0.449 \\
\hline Capitalization/GDP & & $(0.363)$ & $(0.244)$ & $(0.072)$ & $(0.140)$ & $(0.339)$ \\
\hline Market Capitalization/GDP & & $\begin{array}{l}-0.579 \\
(0.809)\end{array}$ & & & & \\
\hline No. Listed Companies & & & $\begin{array}{l}-0.001^{\mathrm{a}} \\
(0.000)\end{array}$ & & & \\
\hline Foreign Portfolio Investments/Market & & & & $-7.120^{\mathrm{a}}$ & & \\
\hline Capitalization & & & & $(0.714)$ & & \\
\hline Turnover Ratio & & & & & $\begin{array}{l}-1.300^{\mathrm{a}} \\
(0.407)\end{array}$ & \\
\hline Value Traded/GDP & & & & & & $\begin{array}{l}-2.685^{\mathrm{b}} \\
(1.338)\end{array}$ \\
\hline French Civil Law & $\begin{array}{l}-0.145 \\
(0.328)\end{array}$ & $\begin{array}{l}-0.024 \\
(0.263)\end{array}$ & $\begin{array}{l}-0.098 \\
(0.261)\end{array}$ & $\begin{array}{c}-0.053 \\
(0.100)\end{array}$ & $\begin{array}{l}-0.340 \\
(0.257)\end{array}$ & $\begin{array}{l}-0.182 \\
(0.423)\end{array}$ \\
\hline German Civil Law & $\begin{array}{l}-0.966^{\mathrm{b}} \\
(0.483)\end{array}$ & $\begin{array}{l}5.098^{\mathrm{a}} \\
(1.309)\end{array}$ & $\begin{array}{l}-0.290 \\
(0.219)\end{array}$ & $*$ & $\begin{array}{l}-0.934^{b} \\
(0.441)\end{array}$ & $\begin{array}{l}-0.612 \\
(0.584)\end{array}$ \\
\hline Scand. Civil Law & $\begin{array}{l}-0.623 \\
(0.458)\end{array}$ & $\begin{array}{l}-0.443^{\mathrm{c}} \\
(0.242)\end{array}$ & $\begin{array}{l}-0.559^{\mathrm{a}} \\
(0.154)\end{array}$ & $*$ & $\begin{array}{l}-0.557^{\mathrm{a}} \\
(0.206)\end{array}$ & $\begin{array}{l}-0.703^{\mathrm{d}} \\
(0.471)\end{array}$ \\
\hline Constant & $\begin{array}{c}2.641^{\mathrm{a}} \\
(0.257)\end{array}$ & $\begin{array}{l}2.287^{a} \\
(0.444)\end{array}$ & $\begin{array}{l}2.387^{a} \\
(0.182)\end{array}$ & $\begin{array}{c}2.397^{\mathrm{a}} \\
(0.013)\end{array}$ & $\begin{array}{l}2.942^{\mathrm{a}} \\
(0.358)\end{array}$ & $\begin{array}{l}2.719^{a} \\
(0.588)\end{array}$ \\
\hline No. Observations & 326 & 123 & 128 & 72 & 130 & 129 \\
\hline Log Likelihood & -49.232 & -5.886 & -6.761 & 2.766 & -4.843 & -8.260 \\
\hline $\mathrm{P}-$ Value of $\mathrm{Chi}^{2}$ & 0.164 & $0.000^{\mathrm{a}}$ & $0.000^{\mathrm{a}}$ & $0.000^{\mathrm{a}}$ & $0.000^{\mathrm{a}}$ & $0.016^{\mathrm{b}}$ \\
\hline
\end{tabular}

Notes: The regression is a Weibull hazard model, where the dependent variable is the log expected time until enforcement of insider trading legislation, that is,

$\ln (T)=x^{\prime} b+e$. Each independent variable is measured for each country in each year. The independent variables are the 1-year growth rate of stock market capitalization relative to GDP; the 3-year growth rate of stock market capitalization relative to GDP; stock market capitalization relative to GDP; the number of listed companies; foreign portfolio investment relative to stock market capitalization; stock market turnover; total value traded relative to GDP; an indicator that equals one if the stock market has been officially liberalized, and zero otherwise; an indicator that equals one for French civil law, and zero otherwise; an indicator that equals one for German civil law, and zero otherwise; and an indicator that equals one for Scandinavian civil law (English common law is the omitted category). All variables are described in detail in the Data Appendix. Robust standard errors are reported in parentheses. The superscripts a, b, c and d denote the $1 \%, 5 \%, 10 \%$, and $15 \%$ significance levels, respectively. $*$ signifies variable is dropped due to collinearity. 
Table 8

Weibull Hazard Model of Financial and Political Determinants of the Enactment and Enforcement of Insider Trading Laws, 1980-1997

Panel A1: Enactment of Insider Trading Law and Competitiveness of Political Process

\begin{tabular}{|c|c|c|c|c|c|c|c|c|c|c|c|c|c|c|c|}
\hline & $\begin{array}{l}\text { 1-Year } \\
\text { Growth }\end{array}$ & $\begin{array}{l}\text { 3-Year } \\
\text { Growth }\end{array}$ & $\begin{array}{c}\text { Market } \\
\text { Cap/GDP }\end{array}$ & $\begin{array}{c}\text { Listed } \\
\text { Companies }\end{array}$ & $\begin{array}{c}\text { Foreign } \\
\text { Inv/Mkt } \\
\text { Cap. }\end{array}$ & $\begin{array}{c}\text { Turnover } \\
\text { Ratio }\end{array}$ & $\begin{array}{c}\text { Value } \\
\text { Traded } \\
\text { /GDP }\end{array}$ & $\begin{array}{c}\text { Official } \\
\text { Liberaliz'n }\end{array}$ & $\begin{array}{l}\text { Political } \\
\text { Checks } \\
\& \text { Bal. }\end{array}$ & $\begin{array}{l}\text { Herfindahl } \\
\text { Index }\end{array}$ & $\begin{array}{l}\text { Gov't } \\
\text { Fract. }\end{array}$ & Const. & Obs. & $\begin{array}{c}\text { Log } \\
\text { Likelihood }\end{array}$ & $\begin{array}{l}\text { P-Value } \\
\text { of Chî }\end{array}$ \\
\hline (1) & & & & & & & & & $\begin{array}{l}-0.076^{\mathrm{c}} \\
(0.040)\end{array}$ & & & $\begin{array}{l}2.694^{\mathrm{a}} \\
(0.150)\end{array}$ & 659 & -62.524 & $0.059^{c}$ \\
\hline (2) & & & & & & & & & & $\begin{array}{c}0.380^{\mathrm{d}} \\
(0.247)\end{array}$ & & $\begin{array}{l}2.338^{\mathrm{a}} \\
(0.112)\end{array}$ & 612 & -43.822 & $0.124^{\mathrm{d}}$ \\
\hline (3) & & & & & & & & & & & $\begin{array}{l}-0.454^{\mathrm{c}} \\
(0.270)\end{array}$ & $\begin{array}{l}2.756^{\mathrm{a}} \\
(0.172)\end{array}$ & 612 & -43.388 & $0.093^{c}$ \\
\hline (4) & $\begin{array}{c}0.921^{\mathrm{b}} \\
(0.383)\end{array}$ & $\begin{array}{l}0.930^{\mathrm{a}} \\
(0.249)\end{array}$ & $\begin{array}{l}-1.295^{\mathrm{a}} \\
(0.415)\end{array}$ & & & & & $\begin{array}{l}-0.249 \\
(0.283)\end{array}$ & $\begin{array}{l}-0.083^{\mathrm{c}} \\
(0.045)\end{array}$ & & & $\begin{array}{l}3.654^{\mathrm{a}} \\
(0.326)\end{array}$ & 237 & -1.732 & $0.000^{\mathrm{a}}$ \\
\hline (5) & $\begin{array}{r}1.765^{\mathrm{b}} \\
(0.854)\end{array}$ & $\begin{array}{l}1.004^{b} \\
(0.432)\end{array}$ & & $\begin{array}{c}0.001 \\
(0.001)\end{array}$ & & & & $\begin{array}{l}-1.082^{\mathrm{d}} \\
(0.749)\end{array}$ & $\begin{array}{l}-0.134^{\mathrm{d}} \\
(0.093)\end{array}$ & & & $\begin{array}{l}3.846^{\mathrm{a}} \\
(0.820)\end{array}$ & 136 & -0.198 & $0.084^{c}$ \\
\hline (6) & $\begin{array}{c}3.839^{\mathrm{b}} \\
(1.788)\end{array}$ & $\begin{array}{c}0.615 \\
(0.471)\end{array}$ & & & $\begin{array}{c}32.454^{\mathrm{c}} \\
(18.866)\end{array}$ & & & $\begin{array}{l}-1.526 \\
(1.115)\end{array}$ & $\begin{array}{l}-0.249^{d} \\
(0.160)\end{array}$ & & & $\begin{array}{l}5.895^{\mathrm{a}} \\
(1.504)\end{array}$ & 113 & -2.017 & $0.001^{\mathrm{a}}$ \\
\hline (7) & $\begin{array}{c}0.774^{\mathrm{a}} \\
(0.287)\end{array}$ & $\begin{array}{c}0.597^{\mathrm{a}} \\
(0.208)\end{array}$ & & & & $\begin{array}{l}-0.226^{\mathrm{c}} \\
(0.119)\end{array}$ & & $\begin{array}{l}-0.343 \\
(0.260)\end{array}$ & $\begin{array}{l}-0.023 \\
(0.006)\end{array}$ & & & $\begin{array}{l}3.139^{\mathrm{a}} \\
(0.234)\end{array}$ & 234 & -4.799 & $0.005^{\mathrm{a}}$ \\
\hline (8) & $\begin{array}{c}0.797^{\mathrm{a}} \\
(0.307)\end{array}$ & $\begin{array}{l}0.850^{\mathrm{a}} \\
(0.252)\end{array}$ & & & & & $\begin{array}{c}0.955 \\
(1.863)\end{array}$ & $\begin{array}{l}-0.468^{\mathrm{d}} \\
(0.298)\end{array}$ & $\begin{array}{l}-0.072 \\
(0.053)\end{array}$ & & & $\begin{array}{l}3.448^{\mathrm{a}} \\
(0.314)\end{array}$ & 226 & -2.679 & $0.001^{\mathrm{a}}$ \\
\hline (9) & $\begin{array}{c}0.605^{\mathrm{a}} \\
(0.203)\end{array}$ & $\begin{array}{c}0.848^{\mathrm{a}} \\
(0.280)\end{array}$ & $\begin{array}{l}-1.082^{\mathrm{a}} \\
(0.406)\end{array}$ & & & & & $\begin{array}{l}-0.279^{d} \\
(0.178)\end{array}$ & & $\begin{array}{l}-0.425^{\mathrm{d}} \\
(0.273)\end{array}$ & & $\begin{array}{l}3.456^{\mathrm{a}} \\
(0.329)\end{array}$ & 223 & 3.369 & $0.024^{\mathrm{b}}$ \\
\hline (10) & $\begin{array}{c}0.899^{\mathrm{a}} \\
(0.313)\end{array}$ & $\begin{array}{l}0.845^{\mathrm{a}} \\
(0.328)\end{array}$ & & $\begin{array}{c}0.000 \\
(0.001)\end{array}$ & & & & $\begin{array}{l}-0.632^{\mathrm{b}} \\
(0.319)\end{array}$ & & $\begin{array}{l}-0.383 \\
(0.439)\end{array}$ & & $\begin{array}{l}3.256^{\mathrm{a}} \\
(0.429)\end{array}$ & 125 & 2.049 & $0.010^{\mathrm{a}}$ \\
\hline (11) & $\begin{array}{c}0.909^{\mathrm{b}} \\
(0.387)\end{array}$ & $\begin{array}{l}1.332^{\mathrm{b}} \\
(0.550)\end{array}$ & & & $\begin{array}{l}-3.618 \\
(9.074)\end{array}$ & & & $\begin{array}{l}-0.725^{\mathrm{d}} \\
(0.473)\end{array}$ & & $\begin{array}{l}-0.623 \\
(0.540)\end{array}$ & & $\begin{array}{l}4.031^{\mathrm{a}} \\
(0.531)\end{array}$ & 100 & 0.198 & $0.002^{\mathrm{a}}$ \\
\hline (12) & $\begin{array}{c}0.519^{\mathrm{a}} \\
(0.160)\end{array}$ & $\begin{array}{l}0.602^{\mathrm{a}} \\
(0.241)\end{array}$ & & & & $\begin{array}{l}-0.217 \\
(0.054)\end{array}$ & & $\begin{array}{l}-0.308^{b} \\
(0.146)\end{array}$ & & $\begin{array}{l}-0.398^{\mathrm{d}} \\
(0.268)\end{array}$ & & $\begin{array}{l}3.187^{\mathrm{a}} \\
(0.245)\end{array}$ & 222 & 1.416 & $0.000^{\mathrm{a}}$ \\
\hline (13) & $\begin{array}{c}0.496^{\mathrm{a}} \\
(0.158)\end{array}$ & $\begin{array}{l}0.807^{\mathrm{a}} \\
(0.309)\end{array}$ & & & & & $\begin{array}{c}0.592 \\
(1.225)\end{array}$ & $\begin{array}{l}-0.396^{\mathrm{a}} \\
(0.158)\end{array}$ & & $\begin{array}{l}-0.361 \\
(0.306)\end{array}$ & & $\begin{array}{l}3.277^{\mathrm{a}} \\
(0.313)\end{array}$ & 214 & 2.533 & $0.007^{\mathrm{a}}$ \\
\hline (14) & $\begin{array}{c}0.610^{\mathrm{a}} \\
(0.204)\end{array}$ & $\begin{array}{l}0.825^{\mathrm{a}} \\
(0.271)\end{array}$ & $\begin{array}{l}-1.031^{\mathrm{b}} \\
(0.429)\end{array}$ & & & & & $\begin{array}{l}-0.272^{\mathrm{d}} \\
(0.177)\end{array}$ & & & $\begin{array}{c}0.328 \\
(0.254)\end{array}$ & & 223 & 3.053 & $0.028^{\mathrm{a}}$ \\
\hline (15) & $\begin{array}{c}0.917^{\mathrm{a}} \\
(0.323)\end{array}$ & $\begin{array}{l}0.835^{\mathrm{a}} \\
(0.324)\end{array}$ & & $\begin{array}{c}0.000 \\
(0.001)\end{array}$ & & & & $\begin{array}{l}-0.609^{b} \\
(0.302)\end{array}$ & & & $\begin{array}{c}0.229 \\
(0.436)\end{array}$ & & 125 & 1.906 & $0.012^{\mathrm{a}}$ \\
\hline
\end{tabular}


Table 8: Panel A1. Continued.

\begin{tabular}{|c|c|c|c|c|c|c|c|c|c|c|c|c|c|c|c|}
\hline & $\begin{array}{l}\text { 1-Year } \\
\text { Growth }\end{array}$ & $\begin{array}{l}3 \text {-Year } \\
\text { Growth }\end{array}$ & $\begin{array}{c}\text { Market } \\
\text { Cap/GDP }\end{array}$ & $\begin{array}{c}\text { Listed } \\
\text { Companies }\end{array}$ & $\begin{array}{c}\text { Foreign } \\
\text { Inv/Mkt } \\
\text { Cap. }\end{array}$ & $\begin{array}{c}\text { Turnover } \\
\text { Ratio }\end{array}$ & $\begin{array}{l}\text { Value } \\
\text { Traded } \\
\text { /GDP }\end{array}$ & $\begin{array}{c}\text { Official } \\
\text { Liberaliz'n }\end{array}$ & $\begin{array}{l}\text { Political } \\
\text { Checks } \\
\& \text { Bal. }\end{array}$ & $\begin{array}{l}\text { Herfindahl } \\
\text { Index }\end{array}$ & $\begin{array}{l}\text { Gov't } \\
\text { Fract. }\end{array}$ & Const. & Obs. & $\begin{array}{c}\text { Log } \\
\text { Likelihood }\end{array}$ & $\begin{array}{l}\text { P-Value } \\
\text { of Chí }\end{array}$ \\
\hline (16) & $\begin{array}{l}0.940^{\mathrm{b}} \\
(0.395)\end{array}$ & $\begin{array}{l}1.341^{\mathrm{b}} \\
(0.555)\end{array}$ & & & $\begin{array}{l}-3.557 \\
(9.143)\end{array}$ & & & $\begin{array}{l}-0.757^{\mathrm{c}} \\
(0.458)\end{array}$ & & & $\begin{array}{c}0.582 \\
(0.529)\end{array}$ & & 100 & 0.111 & $0.003^{\mathrm{a}}$ \\
\hline (17) & $\begin{array}{c}0.524^{\mathrm{a}} \\
(0.162)\end{array}$ & $\begin{array}{c}0.597^{\mathrm{a}} \\
(0.240)\end{array}$ & & & & $\begin{array}{l}-0.220^{\mathrm{a}} \\
(0.055)\end{array}$ & & $\begin{array}{c}-0.303^{b} \\
(0.146)\end{array}$ & & & 0.354 & & 222 & 1.262 & $0.000^{\mathrm{a}}$ \\
\hline (18) & $\begin{array}{l}0.502^{\mathrm{a}} \\
(0.160)\end{array}$ & $\begin{array}{l}0.797^{\mathrm{a}} \\
(0.308)\end{array}$ & & & & & $\begin{array}{c}0.727 \\
(1.234)\end{array}$ & $\begin{array}{l}-0.398^{\mathrm{a}} \\
(0.158)\end{array}$ & & & $\begin{array}{c}(0.2518 \\
0.318 \\
(0.299)\end{array}$ & & 214 & 2.433 & $0.009^{\mathrm{a}}$ \\
\hline
\end{tabular}

Notes: The regression is a Weibull hazard model, where the dependent variable is the log expected time until enactment of insider trading legislation, that is, $\ln (T)=x^{\prime} b+e$. Each independent variable is measured for each country in each year. The independent variables are the 1-year growth rate of stock market capitalization relative to GDP; the 3-year growth rate of stock market capitalization relative to GDP; stock market capitalization relative to GDP; the number of listed companies; foreign portfolio investment relative to stock market capitalization; stock market turnover; total value traded relative to GDP; an indicator that equals one if the stock market has been officially liberalized, and zero otherwise; a measure of political checks and balances; the Herfindahl index of government concentration; and fractionalization of the legislature. All variables are described in detail in the Data Appendix. Robust standard errors are reported in parentheses. The superscripts $\mathrm{a}, \mathrm{b}, \mathrm{c}$ and denote the $1 \%, 5 \%, 10 \%$, and $15 \%$ significance levels, respectively. 
Table 8: Weibull Hazard Model of Financial and Political Determinants. Continued.

Panel A2: Enactment of Insider Trading Law and Political Ideology

\begin{tabular}{|c|c|c|c|c|c|c|c|c|c|c|c|c|c|c|c|c|}
\hline & $\begin{array}{l}\text { 1-Year } \\
\text { Growth }\end{array}$ & $\begin{array}{l}3 \text {-Year } \\
\text { Growth }\end{array}$ & $\begin{array}{c}\text { Market } \\
\text { Cap/GDP }\end{array}$ & $\begin{array}{c}\text { Listed } \\
\text { Companies }\end{array}$ & $\begin{array}{c}\text { Foreign } \\
\text { Inv/Mkt } \\
\text { Cap. }\end{array}$ & $\begin{array}{c}\text { Turnover } \\
\text { Ratio }\end{array}$ & $\begin{array}{l}\text { Value } \\
\text { Traded } \\
\text { /GDP }\end{array}$ & $\begin{array}{c}\text { Official } \\
\text { Liberaliz'n }\end{array}$ & Center & Right & $\begin{array}{l}\text { Center } \\
\text { Dom. }\end{array}$ & $\begin{array}{l}\text { Right } \\
\text { Dom. }\end{array}$ & Const. & Obs. & $\begin{array}{c}\text { Log } \\
\text { Likelihood }\end{array}$ & $\begin{array}{l}\text { P-Value } \\
\text { of Chí }\end{array}$ \\
\hline (1) & & & & & & & & & $\begin{array}{c}0.200 \\
(0.223)\end{array}$ & $\begin{array}{l}-0.118 \\
(0.101)\end{array}$ & & & & 453 & -30.651 & 0.338 \\
\hline (2) & & & & & & & & & & & $\begin{array}{l}4.581^{\mathrm{a}} \\
(0.852)\end{array}$ & $\begin{array}{l}-0.129 \\
(0.098)\end{array}$ & $\begin{array}{l}2.498^{\mathrm{a}} \\
(0.054)\end{array}$ & 444 & -19.989 & $0.000^{\mathrm{a}}$ \\
\hline (3) & $\begin{array}{l}0.687^{\mathrm{c}} \\
(0.399)\end{array}$ & $\begin{array}{l}0.536^{\mathrm{a}} \\
(0.218)\end{array}$ & $\begin{array}{l}-1.156^{\mathrm{a}} \\
(0.372)\end{array}$ & & & & & $\begin{array}{l}-0.253 \\
(0.310)\end{array}$ & $\begin{array}{l}-0.133 \\
(0.139)\end{array}$ & $\begin{array}{l}-0.109 \\
(0.225)\end{array}$ & & & $\begin{array}{l}3.107^{\mathrm{a}} \\
(0.406)\end{array}$ & 162 & 3.016 & $0.004^{\mathrm{a}}$ \\
\hline (4) & $\begin{array}{l}1.547^{\mathrm{b}} \\
(0.757)\end{array}$ & $\begin{array}{l}0.739^{\mathrm{c}} \\
(0.386)\end{array}$ & & $\begin{array}{l}0.002^{\mathrm{c}} \\
(0.001)\end{array}$ & & & & $\begin{array}{l}-0.937^{\mathrm{c}} \\
(0.577)\end{array}$ & $\begin{array}{l}-0.035 \\
(0.225)\end{array}$ & $\begin{array}{l}-0.072 \\
(0.252)\end{array}$ & & & $\begin{array}{l}2.871^{\mathrm{a}} \\
(0.492)\end{array}$ & 80 & 3.725 & 0.407 \\
\hline (5) & $*$ & $*$ & & & $*$ & & & $*$ & $*$ & $*$ & & & $*$ & $*$ & $*$ & $*$ \\
\hline (6) & $\begin{array}{l}0.705^{\mathrm{b}} \\
(0.320)\end{array}$ & $\begin{array}{c}0.415^{\mathrm{b}} \\
(0.184)\end{array}$ & & & & $\begin{array}{l}-0.220^{\mathrm{a}} \\
(0.076)\end{array}$ & & $\begin{array}{l}-0.424^{\mathrm{d}} \\
(0.292)\end{array}$ & $\begin{array}{l}-0.085 \\
(0.131)\end{array}$ & $\begin{array}{l}-0.158 \\
(0.223)\end{array}$ & & & $\begin{array}{l}3.045^{\mathrm{a}} \\
(0.353)\end{array}$ & 165 & 1.709 & $0.026^{\mathrm{b}}$ \\
\hline (7) & $\begin{array}{l}0.620^{\mathrm{b}} \\
(0.272)\end{array}$ & $\begin{array}{l}0.394^{\mathrm{b}} \\
(0.195)\end{array}$ & & & & & $\begin{array}{l}4.029^{\mathrm{a}} \\
(1.248)\end{array}$ & $\begin{array}{l}-0.644^{b} \\
(0.289)\end{array}$ & $\begin{array}{c}0.105 \\
(0.099)\end{array}$ & $\begin{array}{l}-0.091 \\
(0.222)\end{array}$ & & & $\begin{array}{l}2.958^{\mathrm{a}} \\
(0.335)\end{array}$ & 161 & 2.896 & $0.000^{\mathrm{a}}$ \\
\hline (8) & $\begin{array}{l}0.356^{\mathrm{a}} \\
(0.136)\end{array}$ & $\begin{array}{l}0.384^{\mathrm{a}} \\
(0.124)\end{array}$ & $\begin{array}{l}-0.951^{\mathrm{a}} \\
(0.263)\end{array}$ & & & & & $\begin{array}{l}-0.080 \\
(0.129)\end{array}$ & & & $\begin{array}{l}2.723^{\mathrm{a}} \\
(0.705)\end{array}$ & $\begin{array}{l}-0.052 \\
(0.119)\end{array}$ & $\begin{array}{l}2.864^{\mathrm{a}} \\
(0.126)\end{array}$ & 159 & 9.238 & $0.000^{\mathrm{a}}$ \\
\hline (9) & $\begin{array}{l}0.635^{\mathrm{a}} \\
(0.207)\end{array}$ & $\begin{array}{l}0.352^{\mathrm{c}} \\
(0.196)\end{array}$ & & $\begin{array}{l}0.001^{\mathrm{b}} \\
(0.000)\end{array}$ & & & & $\begin{array}{l}-0.367^{b} \\
(0.167)\end{array}$ & & & $\begin{array}{l}3.963^{\mathrm{a}} \\
(1.541)\end{array}$ & $\begin{array}{l}-0.146 \\
(0.233)\end{array}$ & $\begin{array}{l}2.630^{\mathrm{a}} \\
(0.203)\end{array}$ & 79 & 6.671 & $0.000^{\mathrm{a}}$ \\
\hline (10) & * & * & & & $*$ & & & $*$ & & & $*$ & $*$ & & $*$ & $*$ & $*$ \\
\hline (11) & $\begin{array}{l}0.430^{\mathrm{a}} \\
(0.138)\end{array}$ & $\begin{array}{l}0.264^{\mathrm{a}} \\
(0.102)\end{array}$ & & & & $\begin{array}{l}-0.183^{\mathrm{a}} \\
(0.048)\end{array}$ & & $\begin{array}{l}-0.213^{\mathrm{c}} \\
(0.127)\end{array}$ & & & $\begin{array}{l}3.174^{\mathrm{a}} \\
(0.697)\end{array}$ & $\begin{array}{l}-0.032 \\
(0.107)\end{array}$ & $\begin{array}{l}2.786^{\mathrm{a}} \\
(0.121)\end{array}$ & 162 & 7.706 & $0.000^{\mathrm{a}}$ \\
\hline (12) & $\begin{array}{l}0.407^{\mathrm{a}} \\
(0.116)\end{array}$ & $\begin{array}{l}0.218^{\mathrm{b}} \\
(0.104)\end{array}$ & & & & & $\begin{array}{l}2.924^{\mathrm{a}} \\
(0.768)\end{array}$ & $\begin{array}{l}-0.421^{\mathrm{a}} \\
(0.102)\end{array}$ & & & $\begin{array}{l}2.467^{a} \\
(0.882)\end{array}$ & $\begin{array}{l}-0.016 \\
(0.111)\end{array}$ & $\begin{array}{c}2.789^{a} \\
0.107\end{array}$ & 158 & 9.346 & $0.000^{\mathrm{a}}$ \\
\hline
\end{tabular}

Notes: The regression is a Weibull hazard model, where the dependent variable is the log expected time until enactment of insider trading legislation, that is, $\ln (T)=x^{\prime} b+e$. Each independent variable is measured for each country in each year. The independent variables are the 1-year growth rate of stock market capitalization relative to GDP; the 3 -year growth rate of stock market capitalization relative to GDP; stock market capitalization relative to GDP; the number of listed companies; foreign portfolio investment relative to stock market capitalization; stock market turnover; total value traded relative to GDP; an indicator that equals one if the stock market has been officially liberalized, and zero otherwise; an indicator that equals one if the largest government party is Center, and zero otherwise; an indicator that equals one if the largest government party is Right, and zero otherwise (Left is the omitted category); an indicator that equals one if the majority party in the legislature is Center, and zero otherwise; and an indicator that equals one of the majority party in the legislature is Right, and zero otherwise (Left is the omitted category). All variables are described in detail in the Data Appendix. Robust standard errors are reported in parentheses. The superscripts $\mathrm{a}, \mathrm{b}, \mathrm{c}$ and d denote the $1 \%, 5 \%, 10 \%$, and $15 \%$ significance levels, respectively. $*$ signifies that matrix is not positive definite. 
Table 8: Weibull Hazard Model of Financial and Political Determinants. Continued.

\section{Panel B1: Enforcement of Insider Trading Law and Competitiveness of Political Process}

\begin{tabular}{|c|c|c|c|c|c|c|c|c|c|c|c|c|c|c|}
\hline & $\begin{array}{l}1 \text { 1-Year } \\
\text { Growth }\end{array}$ & $\begin{array}{l}3 \text {-Year } \\
\text { Growth }\end{array}$ & $\begin{array}{c}\text { Market } \\
\text { Cap/GDP }\end{array}$ & $\begin{array}{c}\text { Listed } \\
\text { Companies }\end{array}$ & $\begin{array}{c}\text { Foreign } \\
\text { Inv/Mkt } \\
\text { Cap. }\end{array}$ & $\begin{array}{c}\text { Turnover } \\
\text { Ratio }\end{array}$ & $\begin{array}{l}\text { Value } \\
\text { Traded } \\
\text { /GDP }\end{array}$ & $\begin{array}{c}\text { Political } \\
\text { Checks \& } \\
\text { Bal. }\end{array}$ & $\begin{array}{l}\text { Herfindahl } \\
\text { Index }\end{array}$ & $\begin{array}{l}\text { Gov't } \\
\text { Fract. }\end{array}$ & Const. & Obs. & $\begin{array}{c}\text { Log } \\
\text { Likelihood }\end{array}$ & $\begin{array}{c}\text { P-Value of } \\
\mathrm{Chi}^{2}\end{array}$ \\
\hline (1) & & & & & & & & $\begin{array}{l}-0.108^{\circ} \\
(0.045)\end{array}$ & & & $\begin{array}{l}2.758^{a} \\
(0.236)\end{array}$ & 308 & -46.997 & $0.017^{\mathrm{D}}$ \\
\hline (2) & & & & & & & & & $\begin{array}{c}1.810^{\mathrm{c}} \\
(1.081)\end{array}$ & & $\begin{array}{l}1.705^{\mathrm{a}} \\
(0.333)\end{array}$ & 282 & -43.392 & $0.094^{\mathrm{c}}$ \\
\hline (3) & & & & & & & & & & $\begin{array}{l}-1.796^{\mathrm{c}} \\
(1.103)\end{array}$ & $\begin{array}{l}3.505^{\mathrm{a}} \\
(0.793)\end{array}$ & 282 & -43.488 & $0.104^{\mathrm{c}}$ \\
\hline (4) & $\begin{array}{c}0.589^{\mathrm{b}} \\
(0.273)\end{array}$ & $\begin{array}{c}0.756^{\mathrm{c}} \\
(0.456)\end{array}$ & $\begin{array}{l}-0.777 \\
(0.520)\end{array}$ & & & & & $\begin{array}{l}-0.205^{\mathrm{a}} \\
(0.080)\end{array}$ & & & $\begin{array}{l}3.268^{\mathrm{a}} \\
(0.454)\end{array}$ & 137 & -5.417 & $0.014^{\mathrm{a}}$ \\
\hline (5) & $\begin{array}{l}0.611^{\mathrm{a}} \\
(0.176)\end{array}$ & $\begin{array}{l}0.685^{\mathrm{c}} \\
(0.398)\end{array}$ & & $\begin{array}{l}-0.002 \\
(0.000)\end{array}$ & & & & $\begin{array}{l}-0.200^{b} \\
(0.087)\end{array}$ & & & & 140 & -6.891 & $0.003^{\mathrm{a}}$ \\
\hline (6) & $\begin{array}{l}0.140^{\mathrm{b}} \\
(0.059)\end{array}$ & $\begin{array}{l}0.355^{\mathrm{b}} \\
(0.168)\end{array}$ & & & $\begin{array}{l}-8.314 \\
(0.598)\end{array}$ & & & $\begin{array}{l}-0.197^{\mathrm{a}} \\
(0.046)\end{array}$ & & & $\begin{array}{l}3.516^{\mathrm{a}} \\
(0.276)\end{array}$ & 86 & 0.916 & $0.000^{\mathrm{a}}$ \\
\hline (7) & $\begin{array}{l}0.345^{\mathrm{b}} \\
(0.155)\end{array}$ & $\begin{array}{l}0.344^{\mathrm{b}} \\
(0.169)\end{array}$ & & & & $\begin{array}{l}-1.456^{\mathrm{a}} \\
(0.448)\end{array}$ & & $\begin{array}{l}-0.029 \\
(0.100)\end{array}$ & & & $\begin{array}{l}2.897^{\mathrm{a}} \\
(0.421)\end{array}$ & 140 & -6.817 & $0.006^{\mathrm{a}}$ \\
\hline (8) & $\begin{array}{l}0.518^{\mathrm{a}} \\
(0.162)\end{array}$ & $\begin{array}{c}0.916^{\mathrm{d}} \\
(0.579)\end{array}$ & & & & & $\begin{array}{l}-4.914^{\mathrm{b}} \\
(2.115)\end{array}$ & $\begin{array}{l}-0.316^{6} \\
(0.132)\end{array}$ & & & $\begin{array}{l}4.229^{\mathrm{a}} \\
(0.864)\end{array}$ & 143 & -8.631 & $0.002^{\mathrm{a}}$ \\
\hline (9) & $\begin{array}{c}0.451^{\mathrm{d}} \\
(0.311)\end{array}$ & $\begin{array}{c}0.712^{\mathrm{b}} \\
(0.310)\end{array}$ & $\begin{array}{l}-0.102 \\
(0.594)\end{array}$ & & & & & & $\begin{array}{l}3.646^{\mathrm{a}} \\
(1.412)\end{array}$ & & $\begin{array}{l}1.102^{\mathrm{b}} \\
(0.464)\end{array}$ & 124 & -3.697 & $0.000^{\mathrm{a}}$ \\
\hline (10) & $\begin{array}{c}0.703^{\mathrm{a}} \\
(0.260)\end{array}$ & $\begin{array}{c}0.789^{\mathrm{b}} \\
(0.395)\end{array}$ & & $\begin{array}{l}-0.002^{\mathrm{a}} \\
(0.000)\end{array}$ & & & & & $\begin{array}{l}3.776^{\mathrm{a}} \\
(1.433)\end{array}$ & & $\begin{array}{l}1.440^{\mathrm{a}} \\
(0.340)\end{array}$ & 127 & -4.324 & $0.002^{\mathrm{a}}$ \\
\hline (11) & $\begin{array}{l}0.198^{\mathrm{d}} \\
(0.135)\end{array}$ & $\begin{array}{c}0.326 \\
(0.445)\end{array}$ & & & $\begin{array}{l}-7.166^{\mathrm{d}} \\
(4.748)\end{array}$ & & & & $\begin{array}{c}1.360 \\
(2.577)\end{array}$ & & $\begin{array}{l}2.237^{\mathrm{a}} \\
(0.912)\end{array}$ & 73 & -0.495 & $0.000^{\mathrm{a}}$ \\
\hline (12) & $\begin{array}{c}0.397^{\mathrm{b}} \\
(0.181)\end{array}$ & $\begin{array}{c}0.385^{\mathrm{b}} \\
(0.197)\end{array}$ & & & & $\begin{array}{l}-1.395^{\mathrm{a}} \\
(0.405)\end{array}$ & & & $\begin{array}{c}0.048 \\
(0.504)\end{array}$ & & $\begin{array}{l}2.649^{\mathrm{a}} \\
(0.303)\end{array}$ & 128 & -6.003 & $0.008^{\mathrm{a}}$ \\
\hline (13) & $\begin{array}{l}0.524^{\mathrm{a}} \\
(0.173)\end{array}$ & $\begin{array}{c}0.647 \\
(0.460)\end{array}$ & & & & & $\begin{array}{l}-3.026 \\
(2.194)\end{array}$ & & $\begin{array}{l}2.944^{\mathrm{d}} \\
(1.870)\end{array}$ & & $\begin{array}{l}1.704^{\mathrm{b}} \\
(0.766)\end{array}$ & 130 & -8.394 & $0.020^{\mathrm{b}}$ \\
\hline (14) & $\begin{array}{c}0.474^{\mathrm{d}} \\
(0.304)\end{array}$ & $\begin{array}{c}0.702^{\mathrm{b}} \\
(0.326)\end{array}$ & $\begin{array}{l}-0.116 \\
(0.618)\end{array}$ & & & & & & & $\begin{array}{l}-3.405^{b} \\
(1.696)\end{array}$ & $\begin{array}{l}4.556^{\mathrm{a}} \\
(1.266)\end{array}$ & 124 & -4.024 & $0.002^{\mathrm{a}}$ \\
\hline (15) & $\begin{array}{l}0.711^{\mathrm{a}} \\
(0.279)\end{array}$ & $\begin{array}{l}0.772^{\mathrm{c}} \\
(0.413)\end{array}$ & & $\begin{array}{l}-0.002^{\mathrm{a}} \\
(0.000)\end{array}$ & & & & & & $\begin{array}{l}-3.421^{b} \\
(1.668)\end{array}$ & $\begin{array}{l}4.924^{\mathrm{a}} \\
(1.379)\end{array}$ & 127 & -4.683 & $0.006^{\mathrm{a}}$ \\
\hline (16) & $\begin{array}{l}0.209^{\mathrm{c}} \\
(0.111)\end{array}$ & $\begin{array}{c}0.281 \\
(0.379)\end{array}$ & & & $\begin{array}{l}-7.890^{c} \\
(4.411)\end{array}$ & & & & & $\begin{array}{l}-0.794 \\
(2.401)\end{array}$ & $\begin{array}{c}3.218^{b} \\
(1.511)\end{array}$ & 73 & -0.650 & $0.000^{\mathrm{a}}$ \\
\hline (17) & $\begin{array}{l}0.397^{b} \\
(0.182)\end{array}$ & $\begin{array}{c}0.383^{\mathrm{b}} \\
(0.192)\end{array}$ & & & & $\begin{array}{l}-1.424^{\mathrm{a}} \\
(0.415)\end{array}$ & & & & $\begin{array}{c}0.103 \\
(0.494)\end{array}$ & $\begin{array}{l}2.607^{\mathrm{a}} \\
(0.374)\end{array}$ & 128 & -6.00 & $0.009^{\mathrm{a}}$ \\
\hline (18) & $\begin{array}{c}0.548^{\mathrm{a}} \\
(0.186)\end{array}$ & $\begin{array}{c}0.612 \\
(0.462)\end{array}$ & & & & & $\begin{array}{l}-2.993 \\
(2.161)\end{array}$ & & & $\begin{array}{l}-2.490 \\
(1.776)\end{array}$ & $\begin{array}{l}4.312^{\mathrm{a}} \\
(1.338)\end{array}$ & 130 & -8.628 & $0.022^{b}$ \\
\hline
\end{tabular}


Table 8: Notes to Panel B1. Continued.

Notes: The regression is a Weibull hazard model, where the dependent variable is the log expected time until enforcement of insider trading le gislation, that is, $\ln (T)=x^{\prime} b+e$. Each independent variable is measured for each country in each year. The independent variables are the 1-year growth rate of stock market capitalization relative to GDP; the 3 -year growth rate of stock market capitalization relative to GDP; stock market capitalization relative to GDP; the number of listed companies; foreign portfolio investment relative to stock market capitalization; stock market turnover; total value traded relative to GDP; an indicator that equals one if the stock market has been officially liberalized, and zero otherwise; a measure of political checks and balances; the Herfindahl index of government concentration; and fractionalization of the legislature. All variables are described in detail in the Data Appendix. Robust standard errors are reported in parentheses. The superscripts $\mathrm{a}, \mathrm{b}, \mathrm{c}$ and d denote the $1 \%, 5 \%, 10 \%$, and $15 \%$ significance levels, respectively. 
Table 8: Weibull Hazard Model of Financial and Political Determinants. Continued.

Panel B2: Enforcement of Insider Trading Law and Political Ideology

\begin{tabular}{|c|c|c|c|c|c|c|c|c|c|c|c|c|c|c|c|}
\hline & $\begin{array}{l}1 \text { 1-Year } \\
\text { Growth }\end{array}$ & $\begin{array}{l}\text { 3-Year } \\
\text { Growth }\end{array}$ & $\begin{array}{c}\text { Market } \\
\text { Cap/GDP }\end{array}$ & $\begin{array}{c}\text { Listed } \\
\text { Companies }\end{array}$ & $\begin{array}{c}\text { Foreign } \\
\text { Inv/Mkt } \\
\text { Cap. }\end{array}$ & $\begin{array}{c}\text { Turnover } \\
\text { Ratio }\end{array}$ & $\begin{array}{l}\text { Value } \\
\text { Traded } \\
\text { /GDP }\end{array}$ & Center & Right & $\begin{array}{l}\text { Center } \\
\text { Dom. }\end{array}$ & $\begin{array}{l}\text { Right } \\
\text { Dom. }\end{array}$ & Const. & Obs. & $\begin{array}{c}\text { Log } \\
\text { Likelihood }\end{array}$ & $\begin{array}{l}\text { P-Value } \\
\text { of Chr }\end{array}$ \\
\hline (1) & & & & & & & & $\begin{array}{c}0.057 \\
(0.804)\end{array}$ & $\begin{array}{l}-0.668^{\mathrm{a}} \\
(0.438)\end{array}$ & & & $\begin{array}{l}2.773^{\mathrm{a}} \\
(0.377)\end{array}$ & 234 & -37.343 & 0.252 \\
\hline (2) & & & & & & & & & & $\begin{array}{l}10.677^{\mathrm{a}} \\
(1.730)\end{array}$ & $\begin{array}{l}-0.224 \\
(0.434)\end{array}$ & $\begin{array}{l}2.344^{\mathrm{a}} \\
(0.186)\end{array}$ & 221 & -37.531 & $0.000^{\mathrm{a}}$ \\
\hline (3) & * & $*$ & * & & & & & $*$ & * & & & $*$ & $*$ & $*$ & $*$ \\
\hline (4) & $\begin{array}{c}0.333^{\mathrm{d}} \\
(0.228)\end{array}$ & $\begin{array}{l}0.346^{\mathrm{c}} \\
(0.196)\end{array}$ & & $\begin{array}{l}-0.001^{\mathrm{a}} \\
(0.000)\end{array}$ & & & & $\begin{array}{l}-0.540 \\
(1.332)\end{array}$ & $\begin{array}{l}-7.112^{\mathrm{a}} \\
(1.439)\end{array}$ & & & $\begin{array}{l}9.380^{\mathrm{a}} \\
(1.410)\end{array}$ & 107 & -3.787 & $0.000^{\mathrm{a}}$ \\
\hline (5) & $\begin{array}{l}0.204^{\mathrm{a}} \\
(0.053)\end{array}$ & $\begin{array}{l}1.013^{\mathrm{b}} \\
(0.449)\end{array}$ & & & $\begin{array}{l}-9.234^{\mathrm{a}} \\
(1.290)\end{array}$ & & & $\begin{array}{l}-2.327^{\mathrm{a}} \\
(0.714)\end{array}$ & $\begin{array}{l}-3.138^{\mathrm{d}} \\
(2.021)\end{array}$ & & & $\begin{array}{l}5.858^{\mathrm{a}} \\
(1.895)\end{array}$ & 56 & 0.587 & $0.000^{\mathrm{a}}$ \\
\hline (6) & $*$ & $*$ & & & & $*$ & & $*$ & $*$ & & & $*$ & $*$ & $*$ & $*$ \\
\hline (7) & $\begin{array}{l}0.518^{\mathrm{c}} \\
(0.316)\end{array}$ & $\begin{array}{c}0.212 \\
(0.233)\end{array}$ & & & & & $\begin{array}{c}-3.778^{\mathrm{c}} \\
2.152\end{array}$ & $\begin{array}{l}-1.159^{c} \\
(0.653)\end{array}$ & $\begin{array}{c}-12.278^{\mathrm{a}} \\
(3.868)\end{array}$ & & & $\begin{array}{c}14.940^{\mathrm{a}} \\
4.248\end{array}$ & 111 & -5.439 & $0.007^{\mathrm{a}}$ \\
\hline (8) & $\begin{array}{c}0.648^{\mathrm{b}} \\
(0.296)\end{array}$ & $\begin{array}{l}0.231^{\mathrm{d}} \\
(0.155)\end{array}$ & $\begin{array}{l}-1.036^{\mathrm{c}} \\
(0.551)\end{array}$ & & & & & & & $\begin{array}{c}1.562 \\
(2.203)\end{array}$ & $\begin{array}{l}-0.453 \\
(0.407)\end{array}$ & & 95 & -3.487 & $0.000^{\mathrm{a}}$ \\
\hline (9) & $\begin{array}{l}0.680^{a} \\
(0.237)\end{array}$ & $\begin{array}{l}0.210^{\mathrm{c}} \\
(0.125)\end{array}$ & & $\begin{array}{l}-0.001^{\mathrm{a}} \\
(0.000)\end{array}$ & & & & & & $\begin{array}{l}-0.030 \\
(2.228)\end{array}$ & $\begin{array}{l}-0.496 \\
(0.351)\end{array}$ & & 98 & -4.590 & $0.000^{\mathrm{a}}$ \\
\hline (10) & $\begin{array}{l}0.224^{\mathrm{a}} \\
(0.031)\end{array}$ & $\begin{array}{c}0.232 \\
(0.229)\end{array}$ & & & $\begin{array}{l}-6.848^{c} \\
(3.933)\end{array}$ & & & & & $\begin{array}{c}2.022 \\
(2.169)\end{array}$ & $\begin{array}{l}-0.593 \\
(0.505)\end{array}$ & & 47 & -0.426 & $0.000^{\mathrm{a}}$ \\
\hline (11) & $\begin{array}{l}0.410^{\mathrm{b}} \\
(0.186)\end{array}$ & $\begin{array}{l}0.306^{\mathrm{c}} \\
(0.162)\end{array}$ & & & & $\begin{array}{l}-1.514^{\mathrm{a}} \\
(0.459)\end{array}$ & & & & $\begin{array}{l}3.511^{\mathrm{d}} \\
(2.413)\end{array}$ & $\begin{array}{l}-0.487 \\
(0.423)\end{array}$ & & 101 & -5.184 & $0.000^{\mathrm{a}}$ \\
\hline (12) & $\begin{array}{l}0.604^{b} \\
(0.279)\end{array}$ & $\begin{array}{c}0.096^{\mathrm{d}} \\
(0.064)\end{array}$ & & & & & $\begin{array}{l}-3.650^{\mathrm{d}} \\
(2.392)\end{array}$ & & & $\begin{array}{l}5.713^{b} \\
(2.653)\end{array}$ & $\begin{array}{l}-0.850 \\
(0.723)\end{array}$ & $\begin{array}{l}3.002^{\mathrm{a}} \\
(0.787)\end{array}$ & 102 & -6.506 & $0.000^{\mathrm{a}}$ \\
\hline
\end{tabular}

Notes: The regression is a Weibull hazard model, where the dependent variable is the log expected time until enforcement of insider trading legislation, that is, $\ln (T)=x^{\prime} b+e$. Each independent variable is measured for each country in each year. The independent variables are the 1-year growth rate of stock market capitalization relative to GDP; the 3 -year growth rate of stock market capitalization relative to GDP; stock market capitalization relative to GDP; the number of listed companies; foreign portfolio investment relative to stock market capitalization; stock market turnover; total value traded relative to GDP; an indicator that equals one if the stock market has been officially liberalized, and zero otherwise; an indicator that equals one if the largest government party is Center, and zero otherwise; an indicator that equals one if the largest government party is Right, and zero otherwise (Left is the omitted category); an indicator that equals one if the majority party in the legislature is Center, and zero otherwise; and an indicator that equals one of the majority party in the legislature is Right, and zero otherwise (Left is the omitted category). All variables are described in detail in the Data Appendix. Robust standard errors are reported in parentheses. The superscripts $\mathrm{a}, \mathrm{b}, \mathrm{c}$ and denote the $1 \%, 5 \%, 10 \%$, and $15 \%$ significance levels, respectively. $*$ signifies that matrix is not positive definite 
Table 9

Weibull Hazard Model of Financial and Institutional Determinants of the Enactment and Enforcement of Insider Trading Laws,

1980-1997

Panel A: Enactment of Insider Trading Law and Institutional Quality

\begin{tabular}{|c|c|c|c|c|c|c|c|c|c|c|c|c|c|c|c|c|}
\hline & $\begin{array}{r}1 \text { Year } \\
\text { Growth }\end{array}$ & $\begin{array}{r}3 \text { Year } \\
\text { Growth }\end{array}$ & $\begin{array}{c}\text { Mkt Cap/ } \\
\text { GDP }\end{array}$ & Listed Cos & $\begin{array}{c}\text { Foreign } \\
\text { Inv/ } \\
\text { GDP } \\
\end{array}$ & $\begin{array}{c}\text { Turnover } \\
\text { Ratio }\end{array}$ & $\begin{array}{c}\text { Value } \\
\text { Traded/ } \\
\text { GDP }\end{array}$ & $\begin{array}{c}\text { Official } \\
\text { Lib. }\end{array}$ & $\begin{array}{l}\text { Corrupt } \\
\text { Index }\end{array}$ & Catholic & Muslim & $\begin{array}{l}\text { Other } \\
\text { Relig'n }\end{array}$ & Const. & Obs. & $\begin{array}{c}\log \\
\text { Likelihood }\end{array}$ & $\begin{array}{c}\text { P-Value of } \\
\mathrm{Chi}^{2}\end{array}$ \\
\hline (1) & & & & & & & & & $\begin{array}{l}-0.027 \\
(0.033)\end{array}$ & & & & $\begin{array}{l}2.625^{\mathrm{a}} \\
(0.248)\end{array}$ & 438 & -40.587 & 0.410 \\
\hline (2) & $\begin{array}{l}0.959^{\mathrm{a}} \\
(0.384)\end{array}$ & $\begin{array}{l}1.008^{\mathrm{c}} \\
(0.293)\end{array}$ & $\begin{array}{c}-1.082^{\mathrm{b}} \\
(0.519)\end{array}$ & & & & & $\begin{array}{l}-0.276 \\
(0.231)\end{array}$ & $\begin{array}{l}-0.093 \\
(0.069)\end{array}$ & & & & $\begin{array}{l}4.093^{\mathrm{a}} \\
(0.650)\end{array}$ & 222 & -4.108 & $0.004^{\mathrm{a}}$ \\
\hline (3) & $\begin{array}{l}2.236^{\mathrm{a}} \\
(0.620)\end{array}$ & $\begin{array}{c}1.481^{\mathrm{b}} \\
(0.642)\end{array}$ & & $\begin{array}{c}0.002^{\mathrm{b}} \\
(0.001)\end{array}$ & & & & $\begin{array}{c}-0.800^{b} \\
(0.392)\end{array}$ & $\begin{array}{l}-0.367^{\mathrm{a}} \\
(0.112)\end{array}$ & & & & $\begin{array}{l}5.947^{\mathrm{a}} \\
(1.292)\end{array}$ & 127 & 2.603 & $0.002^{\mathrm{a}}$ \\
\hline (4) & $\begin{array}{l}1.977^{\mathrm{c}} \\
(1.057)\end{array}$ & $\begin{array}{l}2.561^{\mathrm{c}} \\
(0.989)\end{array}$ & & & $\begin{array}{c}4326.0^{c} \\
(708.31)\end{array}$ & & & $\begin{array}{l}-1.878^{\mathrm{a}} \\
(0.489)\end{array}$ & & & & & $\begin{array}{l}7.331^{\mathrm{a}} \\
(1.282)\end{array}$ & 99 & -2.444 & $0.000^{\mathrm{a}}$ \\
\hline (5) & $\begin{array}{l}0.842^{\mathrm{a}} \\
(0.296)\end{array}$ & $\begin{array}{l}0.633^{c} \\
(0.239)\end{array}$ & & & & $\begin{array}{l}-0.190 \\
(0.147)\end{array}$ & & $\begin{array}{l}-0.277 \\
(0.200)\end{array}$ & $\begin{array}{l}-0.081 \\
(0.067)\end{array}$ & & & & $\begin{array}{l}3.642^{\mathrm{a}} \\
(0.562)\end{array}$ & 219 & -6.380 & $0.009^{\mathrm{a}}$ \\
\hline (6) & $\begin{array}{l}0.841^{\mathrm{a}} \\
(0.286)\end{array}$ & $\begin{array}{l}0.861^{\mathrm{c}} \\
(0.302)\end{array}$ & & & & & $\begin{array}{l}3.396^{\mathrm{c}} \\
(1.982)\end{array}$ & $\begin{array}{l}-0.508^{\mathrm{a}} \\
(0.218)\end{array}$ & $\begin{array}{l}-0.112^{\mathrm{d}} \\
(0.077)\end{array}$ & & & & $\begin{array}{l}3.999^{\mathrm{a}} \\
(0.633)\end{array}$ & 211 & -4.003 & $0.017^{\mathrm{b}}$ \\
\hline (7) & & & & & & & & & & $\begin{array}{l}0.003^{\mathrm{d}} \\
(0.002)\end{array}$ & $\begin{array}{l}0.004^{\mathrm{d}} \\
(0.003)\end{array}$ & $\begin{array}{c}0.000 \\
(0.003)\end{array}$ & $\begin{array}{l}2.279^{\mathrm{a}} \\
(0.184)\end{array}$ & 729 & -68.955 & 0.214 \\
\hline (8) & $\begin{array}{l}0.919^{\mathrm{a}} \\
(0.372)\end{array}$ & $\begin{array}{l}0.797^{\mathrm{c}} \\
(0.240)\end{array}$ & $\begin{array}{l}-1.122^{c} \\
(0.358)\end{array}$ & & & & & $\begin{array}{l}-0.238 \\
(0.191)\end{array}$ & & $\begin{array}{l}0.005^{\mathrm{c}} \\
(0.003)\end{array}$ & $\begin{array}{l}0.009^{b} \\
(0.004)\end{array}$ & $\begin{array}{c}0.001 \\
(0.002)\end{array}$ & $\begin{array}{l}2.946^{\mathrm{a}} \\
(0.417)\end{array}$ & 237 & 0.322 & $0.000^{\mathrm{a}}$ \\
\hline (9) & $\begin{array}{l}1.487^{\mathrm{c}} \\
(0.823)\end{array}$ & $\begin{array}{l}0.880^{\mathrm{b}} \\
(0.440)\end{array}$ & & $\begin{array}{c}0.000 \\
(0.001)\end{array}$ & & & & $\begin{array}{l}-0.709 \\
(0.688)\end{array}$ & & $\begin{array}{l}0.008^{\mathrm{b}} \\
(0.004)\end{array}$ & $\begin{array}{l}0.016^{\mathrm{c}} \\
(0.009)\end{array}$ & $\begin{array}{c}0.007 \\
(0.005)\end{array}$ & $\begin{array}{l}2.476^{\mathrm{a}} \\
(0.434)\end{array}$ & 136 & 0.741 & $0.006^{\mathrm{a}}$ \\
\hline $\begin{array}{l}(1 \\
0)\end{array}$ & $\begin{array}{l}3.331^{\mathrm{c}} \\
(1.148)\end{array}$ & $\begin{array}{c}0.931 \\
(1.040)\end{array}$ & & & $\begin{array}{c}19.603^{b} \\
(10.133)\end{array}$ & & & $\begin{array}{c}-1.771^{\mathrm{b}} \\
0.735\end{array}$ & & $\begin{array}{l}-0.016 \\
(0.019)\end{array}$ & $\begin{array}{l}-0.002 \\
(0.019)\end{array}$ & $\begin{array}{l}-0.017 \\
(0.020)\end{array}$ & $\begin{array}{l}6.277^{\mathrm{a}} \\
(1.883)\end{array}$ & 113 & -0.519 & $0.001^{\mathrm{a}}$ \\
\hline $\begin{array}{l}(1 \\
1)\end{array}$ & $\begin{array}{l}0.822^{\mathrm{c}} \\
(0.296)\end{array}$ & $\begin{array}{l}0.573^{\mathrm{c}} \\
(0.208)\end{array}$ & & & & $\begin{array}{c}-0.166^{b} \\
(0.069)\end{array}$ & & $\begin{array}{l}-0.325^{\mathrm{c}} \\
(0.176)\end{array}$ & & $\begin{array}{c}0.004 \\
(0.003)\end{array}$ & $\begin{array}{l}0.008^{\mathrm{c}} \\
(0.004)\end{array}$ & $\begin{array}{l}-0.001 \\
(0.004)\end{array}$ & $\begin{array}{l}2.825^{\mathrm{a}} \\
(0.377)\end{array}$ & 234 & -2.010 & $0.000^{\mathrm{a}}$ \\
\hline $\begin{array}{l}(1 \\
2)\end{array}$ & $0.814^{\mathrm{c}}$ & $0.800^{\mathrm{c}}$ & & & & & 1.337 & $-0.444^{b}$ & & $0.005^{\mathrm{c}}$ & $0.009^{b}$ & 0.002 & $2.760^{\mathrm{a}}$ & 226 & -1.520 & $0.000^{\mathrm{a}}$ \\
\hline
\end{tabular}

Notes: The regression is a Weibull hazard model, where the dependent variable is the log expected time until enactment of insider trading legislation, that is, $\ln (T)=x^{\prime} b+e$. Each independent variable is measured for each country in each year. The independent variables are the 1-year growth rate of stock market capitalization relative to GDP; the 3 year growth rate of stock market capitalization relative to GDP; stock market capitalization relative to GDP; the number of listed companies; foreign portfolio investment relative to stock market capitalization; stock market turnover; total value traded relative to GDP; an indicator that equals one if the stock market has been officially liberalized, and zero otherwise; an index of corruption; the percentage of the population that is Catholic; the percentage of the population that is Muslim; and the percentage of the population that adheres to "other religions" (the omitted religion is Protestant). All variables are described in detail in the Data Appendix. Robust standard errors are reported in parentheses. The superscripts a, b, c and denote the $1 \%, 5 \%, 10 \%$, and $15 \%$ significance levels, respectively. 
Table 9: Weibull Hazard Model of Financial and Institutional Determinants. Continued.

Panel B: Enforcement of Insider Trading Law and Institutional Quality

\begin{tabular}{|c|c|c|c|c|c|c|c|c|c|c|c|c|c|c|c|}
\hline & $\begin{array}{l}1 \text { Year } \\
\text { Growth }\end{array}$ & $\begin{array}{c}3 \text { Year } \\
\text { Growth }\end{array}$ & $\begin{array}{l}\text { Mkt Cap/ } \\
\text { GDP }\end{array}$ & Listed Cos & $\begin{array}{l}\text { Foreign Inv/ } \\
\text { GDP }\end{array}$ & $\begin{array}{c}\text { Turnover } \\
\text { Ratio }\end{array}$ & $\begin{array}{c}\text { Value } \\
\text { Traded/ } \\
\text { GDP }\end{array}$ & $\begin{array}{l}\text { Corrupt } \\
\text { Index }\end{array}$ & Catholic & Muslim & Other Relig'n & Const. & Obs. & Log Likelihood & $\begin{array}{c}\text { P-Value of } \\
\mathrm{Chi}^{2}\end{array}$ \\
\hline (1) & & & & & & & & $\begin{array}{l}-0.121^{\mathrm{c}} \\
(0.074)\end{array}$ & & & & $\begin{array}{c}3.241^{\mathrm{a}} \\
(0.599)\end{array}$ & 265 & -39.935 & $0.101^{c}$ \\
\hline (2) & $\begin{array}{l}0.363^{\mathrm{c}} \\
(0.219)\end{array}$ & $\begin{array}{c}0.396^{\mathrm{c}} \\
(0.243)\end{array}$ & $\begin{array}{l}-0.942^{\mathrm{d}} \\
(0.610)\end{array}$ & & & & & $\begin{array}{l}-0.022 \\
(0.033)\end{array}$ & & & & $\begin{array}{l}2.639^{\mathrm{a}} \\
(0.381)\end{array}$ & 122 & -5.219 & 0.408 \\
\hline (3) & $\begin{array}{l}0.415^{\mathrm{c}} \\
(0.227)\end{array}$ & $\begin{array}{c}0.310^{\mathrm{c}} \\
(0.161)\end{array}$ & & $\begin{array}{l}-0.001^{\mathrm{a}} \\
(0.000)\end{array}$ & & & & $\begin{array}{l}-0.004 \\
(0.056)\end{array}$ & & & & $\begin{array}{l}2.486^{\mathrm{a}} \\
(0.381)\end{array}$ & 122 & -6.394 & $0.000^{\mathrm{a}}$ \\
\hline (4) & $*$ & $*$ & & & $*$ & & & $*$ & & & & $*$ & $*$ & $*$ & $*$ \\
\hline (5) & $\begin{array}{l}0.202^{\mathrm{b}} \\
(0.099)\end{array}$ & $\begin{array}{c}0.279^{\mathrm{b}} \\
(0.139)\end{array}$ & & & & $\begin{array}{l}-1.646^{\mathrm{a}} \\
(0.280)\end{array}$ & & $\begin{array}{l}-0.094^{\mathrm{a}} \\
(0.014)\end{array}$ & & & & $\begin{array}{c}3.537^{\mathrm{a}} \\
(0.270)\end{array}$ & 125 & -4.982 & $0.000^{\mathrm{a}}$ \\
\hline (6) & $\begin{array}{l}0.495^{\mathrm{c}} \\
(0.262)\end{array}$ & $\begin{array}{c}0.182 \\
(0.246)\end{array}$ & & & & & $\begin{array}{l}-2.999 \\
(2.156)\end{array}$ & $\begin{array}{l}-0.139 \\
(0.100)\end{array}$ & & & & $\begin{array}{l}3.961^{\mathrm{a}} \\
(1.003)\end{array}$ & 124 & -7.091 & $0.058^{c}$ \\
\hline (7) & & & & & & & & & $\begin{array}{c}0.003 \\
(0.005)\end{array}$ & $\begin{array}{c}0.007 \\
(0.005)\end{array}$ & $\begin{array}{c}0.001 \\
(0.006)\end{array}$ & $\begin{array}{l}2.210^{\mathrm{a}} \\
(0.437)\end{array}$ & 390 & -59.613 & 0.444 \\
\hline (8) & $\begin{array}{c}0.316^{\mathrm{a}} \\
(0.109)\end{array}$ & $\begin{array}{c}0.521 \\
(0.381)\end{array}$ & $\begin{array}{l}-0.466 \\
(0.621)\end{array}$ & & & & & & $\begin{array}{c}0.003 \\
(0.005)\end{array}$ & $\begin{array}{c}0.023 \\
(0.022)\end{array}$ & $\begin{array}{l}0.005^{\mathrm{d}} \\
(0.003)\end{array}$ & $\begin{array}{l}1.840^{\mathrm{a}} \\
(0.218)\end{array}$ & 137 & -6.675 & $0.041^{\mathrm{b}}$ \\
\hline (9) & $\begin{array}{l}0.420^{\mathrm{a}} \\
(0.146)\end{array}$ & $\begin{array}{c}0.433^{\mathrm{d}} \\
(0.288)\end{array}$ & & $\begin{array}{l}-0.001 \\
(0.000)\end{array}$ & & & & & $\begin{array}{c}0.005 \\
(0.005)\end{array}$ & $\begin{array}{c}0.028 \\
(0.032)\end{array}$ & $\begin{array}{c}0.005 \\
(0.004)\end{array}$ & $\begin{array}{l}1.914^{\mathrm{a}} \\
(0.213)\end{array}$ & 141 & -8.277 & $0.006^{\mathrm{a}}$ \\
\hline (10) & $\begin{array}{l}-0.011^{\mathrm{a}} \\
(0.002)\end{array}$ & $\begin{array}{c}0.329^{\mathrm{a}} \\
(0.052)\end{array}$ & & & $\begin{array}{l}-5.906^{\mathrm{a}} \\
(0.430)\end{array}$ & & & & $\begin{array}{l}-0.003 \\
(0.003)\end{array}$ & $\begin{array}{l}0.107^{\mathrm{a}} \\
(0.016)\end{array}$ & $\begin{array}{l}-0.006^{d} \\
(0.004)\end{array}$ & $\begin{array}{l}2.542^{\mathrm{a}} \\
(0.324)\end{array}$ & 86 & 2.177 & $0.000^{\mathrm{a}}$ \\
\hline (11) & $\begin{array}{l}0.324^{b} \\
(0.165)\end{array}$ & $\begin{array}{c}0.277 \\
(0.203)\end{array}$ & & & & $\begin{array}{c}-1.356^{\mathrm{a}} \\
(0.510)\end{array}$ & & & $\begin{array}{c}0.003 \\
(0.005)\end{array}$ & $\begin{array}{c}0.078 \\
(0.189)\end{array}$ & $\begin{array}{c}0.000 \\
(0.010)\end{array}$ & $\begin{array}{l}2.441^{\mathrm{a}} \\
(0.366)\end{array}$ & 141 & -6.139 & $0.001^{\mathrm{a}}$ \\
\hline (12) & $\begin{array}{c}0.412^{\mathrm{b}} \\
(0.194)\end{array}$ & $\begin{array}{c}0.389 \\
(0.320)\end{array}$ & & & & & $\begin{array}{l}-2.646^{c} \\
(1.562)\end{array}$ & & $\begin{array}{c}0.000 \\
(0.010)\end{array}$ & $\begin{array}{c}0.052 \\
(0.115)\end{array}$ & $\begin{array}{l}-0.001 \\
(0.010)\end{array}$ & $\begin{array}{l}2.453^{\mathrm{a}} \\
(0.934)\end{array}$ & 143 & -9.658 & 0.045 \\
\hline
\end{tabular}

Notes: The regression is a Weibull hazard model, where the dependent variable is the log expected time until enforcement of insider trading legislation, that is, $\ln (T)=x^{\prime} b+e$. Each independent variable is measured for each country in each year. The independent variables are the 1-year growth rate of stock market capitalization relative to GDP; the 3-year growth rate of stock market capitalization relative to GDP; stock market capitalization relative to GDP; the number of listed companies; foreign portfolio investment relative to stock market capitalization; stock market turnover; total value t raded relative to GDP; an indicator that equals one if the stock market has been officially liberalized, and zero otherwise; an index of corruption; the percentage of the population that is Catholic; the percentage of the population that is Muslim; and the percentage of the population that adheres to "other religions" (the omitted religion is Protestant). All variables are described in detail in the Data Appendix. Robust standard errors are reported in parentheses. The superscripts a, b, c and d denote the $1 \%, 5 \%, 10 \%$, and $15 \%$ significance levels, respectively. $*$ signifies that matrix is not positive definite. 